\title{
Transformacja energetyki (za pomocą reformy ustrojowej rynku energii elektrycznej) do monizmu elektrycznego odna- wialnych źródeł energii 2050 - Raport
}

\author{
Transformation of Energy (by the New Competitive Electricity \\ Market) to Electric Monism Renewable Energy 2050
}

\section{Jan Popczyk}

Powszechna Platforma Transformacyjna Energetyki 2050

E-mail: jan.popczyk@ep2050.pl

ORCID: https:// orcid.org/00oo-0002-4313-950X

Abstract

The report discusses topics related to energy transformation in Poland in 2050 horizon, in a new manner, with the aim of contributing to the debate on this topic. The transformation is not possible without a new, competitive (that means real time) electricity market, and the challenging process of restructuring fossil fuels sectors. Electric monism (2050) based on RES is a comprehensive review of factors that will determine the needed transformation. The proposals presented in the report are based on the following paradigmatic triplet: prosumers, exergy and virtualization (the last one related to the power industry). In practice the transformation to the RES electric monism means: RES re-electrification of the power industry, electrification of heating (heating pumps) - after completing the process of applying passive design concepts to buildings (existing and new) - and electrification of transport (electric vehicles).

Keywords - energy transformation, a new competitive electricity market, renewable electricity monism 2050 
Bez dorobku profesorów Michała Hellera i Jana Szarguta, bez książki Serce Europy Daviesa Normana ten Raport - poświęcony transformacji energetyki „od reformy do rynku” - nie powstałby

\section{Diagnoza}

Utworzenie w roku 2000 Południowego Koncernu Energetycznego zapoczątkowało w Polsce odwrót od rynkowej reformy elektroenergetyki (decentralizacyjno-liberalizacyjnej i prywatyzacyjnej), której koncepcja w trybie oddolnym powstawała w roku 1989, a rząd podją decyzję o jej realizacji w roku 1990. Odwrót nastapił w najgorszym czasie, kiedy na świecie zaczęła się cywilizacyjna konsolidacja polityki klimatyczno-energetycznej, a Niemcy, UE, Chiny, USA bezpośrednio w jej nurcie, bądź pośrednio, rozpoczęły przebudowę energetyki w celu zdobycia przewagi technologicznej i usankcjonowania nowego globalnego układu sił.

Po roku 2000 kolejnymi (charakterystycznymi) krokami spychającymi cała polska energetykę w etatystyczny (zarazem neokolonialny) model były: ustrojowa recentralizacja elektroenergetyki (z jej szczytową fazą w latach 2005-2010), „restrukturyzacyjna” recentralizacja górnictwa (lata 2003-2016), przejęcia (nieliczne, ale ustrojowo ważne) kopalń węgla kamiennego przez „państwowe” grupy elektroenergetyczne, konsolidacja kapitałowa elektroenergetyki i górnictwa węgla kamiennego (,inwestycje” kapitałowe grup elektroenergetycznych w górnictwo węgla kamiennego).

Duże znaczenie ma w tym procesie polityka energetyczna Polski. Zwłaszcza polityka przyjęta w roku 2009 (Polityka Energetycz̨na Polski 2030), wprowadzająca irracjonalny program rozwojowy energetyki jądrowej - 4 bloki, każdy o mocy $1600 \mathrm{MW}$ - z pierwszymi dwoma planowanymi do uruchomienia, w tamtej polityce, w roku 2020). Nie mniej ważny jest projekt polityki PEP 2040 ogłoszony w końcu 2018 roku według którego Polska w górnym wariacie wybuduje do roku 2040 sześć bloków, każdy o mocy 1500 MW, a zużycie paliw kopalnych w roku 2050 będzie wynosić: węgiel kamienny - $40 \mathrm{mln}$ ton, ropa naftowa $-26 \mathrm{mln}$ ton, gaz ziemny $-22 \mathrm{mld} \mathrm{m}^{3}$.

Charakterystyczne skutki odwrotu od rynkowej reformy elektroenergetyki są dla Polski dotkliwe. W roku 2004 eksport (saldo) energii elektrycznej wynosił $+11,2 \%$, w roku 
2016 saldo było praktycznie zerowe, a w roku 2018 import (saldo) osiagnął poziom $-5,7 \%$. Roczny import węgla kamiennego w roku 2018 osiagnął poziom $20 \mathrm{mln}$ ton. Ceny hurtowe energii elektrycznej na rynku europejskim (na rynkach dnia następnego) są w Polsce przeciętnie o 15\% wyższe niż w krajach sąsiednich. Spadek wartości giełdowej grup elektroenergetycznych (powstałych w wyniku recentralizacji elektroenergetyki) względem notowań maksymalnych, około $70 \%$ (w świetle fundamentalnej analizy wartości grup jest jeszcze gorzej); nie można zapominać o wartości funduszu emerytalnego. Ujawniony deficyt zdolności przyłączeniowych do sieci średnich i niskich napiecć (SN-nN) w roku 2018 wynosił prawie 500 MW (na taką moc operatorzy dystrybucyjni odrzucili wnioski przyłączeniowe - o dostawę energii elektrycznej - złożone przez odbiorców).

$* * *$

Przedstawione liczby oznaczaja stan przedzawałowy polskiej elektroenergetyki. Strat nie da się już odrobić. Tym, co trzeba zrobić, nie jest ratowanie istniejącej elektroenergetyki. Wyzwaniem (trudnym zadaniem) jest pokonanie ukształtowanych historycznie korporacyjno-politycznych grup interesów i zastapienie całej energetyki paliw kopalnych oraz dotychczasowych sposobów użytkowania energii elektrycznej, ciepła i paliw transportowych wytwarzanych z paliw kopalnych nowa „,energetyka”, zaspakajajaca wszystkie potrzeby energetyczne w sposób odmienny od dotychczasowego. Zatem tym, czego potrzebuje realna gospodarka, jest zbudowanie nowej energetyki.

\section{Cel transformacji}

Jest nim zbudowanie nowej energetyki w procesie inteligentnej reelektryfikacji polegającej na zastąpieniu źródeł wytwórczych węglowych i gazowych odnawialnymi źródła energii (OZE) (wykorzystującej na wielką skalę technologie cyfrowe, przemysł technologii informacyjno-komunikacyjnych - ICT) oraz realizacja powiązanych bezpośrednio z tą reelektryfikacją równoległych, wielkich procesów przebudowy zasobów budowlanych (budownictwa) i transportu.

W budownictwie jest to przebudowa polegająca na pasywizacji (dom pasywny) $\mathrm{i}$ inteligentnej elektryfikacji (pompa ciepła), a w transporcie na inteligentnej elektryfikacji (samochód elektryczny). Budowa nowej energetyki oznacza dodatkowo wyjście na silne 
powiązania z rolnictwem (rolnictwo energetyczne) oraz z cała gospodarką obiegu zamkniętego. Inaczej, zbudowanie nowej (technologicznie) energetyki oznacza transformację do monizmu elektrycznego OZE, który cechuje się fundamentalnie wyższą (wielokrotnie) efektywnością termodynamiczną i ekonomiczna, w porównaniu z energetyką paliw kopalnych wielkoskalowej energetyki korporacyjnej (WEK $\left.{ }^{1}\right)$.

Transformacji energetyki paliw kopalnych do monizmu elektrycznego OZE nie da się przeprowadzić inaczej jak tylko za pomocą mechanizmów rynkowych. Rola arbitra między starym i nowym w naturalny sposób przysługuje rynkowi energii elektrycznej (ta „naturalność” w immanentny sposób jest związana z transformacją energetyki do monizmu elektrycznego OZE związanego z rozwojem technologicznym) oraz z procesami społecznymi.

Wszystkie trzy obszary rynkowej transformacji energetyki (reelektryfikacja OZE, pasywizacja zasobów budowlanych oraz inteligentna elektryfikacja ciepłownictwa i inteligentna elektryfikacja transportu) uderzają w ustępującą energetykę WEK (wszystkie jej sektory) i to w niej wystapią koszty restrukturyzacji, które ujawnią się w syntetyczny sposób na rynku schodzącym energii elektrycznej WEK.

Beneficjentami transformacji do monizmu elektrycznego OZE będą rynki wschodzacce energii elektrycznej: rynek 1) - na istniejącej infrastrukturze sieciowej SN-nN i rynek 2) - offshorowy na infrastrukturze dosyłowej (zbudowanej z wykorzystaniem istniejacej sieci 400-220-110 kV).

Jest zrozumiałe, że to rynek schodzący WEK musi się dostosować do rynków wschodzących 1) oraz 2), a nie odwrotnie; w praktyce oznacza to, że niedopuszczalne są jakiekolwiek transfery, zarówno budżetowe, jak i z rynków wschodzących 1) i 2), na rzecz rynku schodzącego WEK.

Z drugiej strony, ustrojowa reforma rynku energii elektrycznej (do postaci zapewniającej transformację energetyki do monizmu elektrycznego OZE) musi - w stopniu

\footnotetext{
${ }^{1}$ Użyty tu akronim wprowadziłem kilkanaście lat temu. On się przyjął, ale bardziej w nowej energetyce. Stara energetyka była mu niechętna, co jest zrozumiałe. Kojarzyła go ze słoikiem z zakonserwowanymi produktami. I słusznie, takie było moje przesłanie. Ostatnio jednak „prawdziwi” energetycy też zaczynaja używać akronimu. I jeszcze jedno. Stosuję zapis „energetyka WEK”, co oznacza wielkoskalową energetykę korporacyjną w całości (górnictwo, elektroenergetyka, sektor paliw płynnych, gazownictwo, ciepłownictwo) oraz zapis „elektroenergetyka WEK” - to oznacza 4 grupy energetyczne: Zespół Elektrowni Patnów Adamów Konin SA, Innogy, PKP Energetyka, ale oczywiście już nie ponad 170 koncesjonowanych operatorów, którzy nie są przyłączeni do sieci przesyłowych - najwyższych napięć (OSDn). Taką konwencję przyjęto dalej w tym Raporcie.
} 
adekwatnym do fundamentalnej efektywności tej transformacji - zapewnić finansowanie „małej” unifikacji sprawiedliwej transformacji. Tego wymaga ustrojowy charakter reformy rynku energii elektrycznej (każda rynkowa transformacja we współczesnym świecie wymaga rozwiązania problemów społecznych, które ta transformacja nieuchronnie wytworzy). Konsekwentnie zatem, celem „towarzyszącym” reformy energetyki rynku energii elektrycznej jest zapewnienie osłony dla rynkowej transformacji (energetyki). Oznacza to, że transformacja musi się odbywać pod osłoną umowy społecznej, dotyczącej alokacji korzyści i kosztów z nią związanych.

Chodzi tu o osłonę w postaci programu małej unifikacji socjalnej, czyli w postaci sprawiedliwej transformacji, obejmującej trzy obszary. Pierwszym jest „sprawiedliwa” transformacja pracownicza w energetyce schodzącej WEK (szacunkowo powinna objąć nie więcej niż 20\% zatrudnionych w samej energetyce i nie więcej niż $10 \%$ w jej bezpośrednim zapleczu kooperacyjnym).

Drugim sa obecni „wrażliwi” odbiorcy energii elektrycznej. Ich sytuacja będzie podlegać dynamicznym zmianom (podkreśla się, że sama transformacja energetyki nie niesie z sobą ryzyka rozszerzania się strefy wykluczenia na rynku energii elektrycznej, monizm elektryczny ułatwia wręcz rozwiazywanie problemów odbiorców wrażliwych za pomoca wielkiej gamy rozwiązań, w tym „bezsieciowych” rynków urządzeń i usług energetyki prosumenckiej).

Trzecim obszarem są odbiorcy tu nazywani „biernymi”. Wśród nich są w szczególności niezdolni do zmiany statusu na prosumencki (ze względu na obiektywny brak potencjału osobniczego do zmiany statusu odbiorcy na status prosumenta). Ale także niezainteresowani zmianą statusu na prosumencki, mimo posiadania wystarczającego potencjału osobniczego, z natury roszczeniowi w zakresie dostępu do taniej energii elektrycznej na koszt innych, czyli zwolennicy politycznych systemów redystrybucyjnych. Ich sytuacja będzie podlegać także dynamicznym zmianom, całkowicie spójnym z właściwościami procesów społeczno-gospodarczych: mikro- i makroekonomicznych.

W tym miejscu rozpoczyna się zdecydowanie polityczny wymiar reformy energetyki. Sprowadza się on do trudnej przebudowy grup interesów na nowocześniejsze, zdolne sprostać globalnym wyzwaniom (zdolne minimalizować wykluczenia, za to maksymalizować wykorzystanie szans wynikających z megatrendów). Wymiar ten sprowadza się 
zatem do wyboru priorytetu politycznego, opowiedzenia się po jednej z dwóch stron: energetyki schodzącej bądź wschodzącej. Opowiedzenie się po pierwszej stronie oznacza sojusz z zasiedziałymi wąskimi grupami interesów korporacyjnych i oznacza polityczne samobójstwo, bo trendu schodzącego energetyki WEK żadne siły nie są już w stanie zahamować (nie jest możliwe wykorzystanie przez polityków i wąskie grupy interesów korporacyjnych taktyki: coś poprawimy aby nic nie zmienić).

Druga strona, gdzie są (ujawnili się już) masowi pretendenci do nowej energetyki (wschodzącej) stoi przed historyczną szansa możliwą do wykorzystania tylko w trybie innowacji przełomowej. Oczywiście, myślenie kategoriami innowacji przełomowej nie jest jeszcze powszechne wśród pretendentów. Stworzenie języka technicznego umożliwiającego myślenie i mówienie o transformacji energetyki jako innowacji przełomowej jest zadaniem nauki (profesorów) oraz elitarnej edukacji, i potrwa lata. Praktyczne znaczenie ma natomiast fakt, że masowi pretendenci są zdolni (gotowi) od zaraz do wykorzystania dostępnego już na szeroką skalę postępu technologicznego (,zdemokratyzowanych" innowacji).

Ci pretendenci, to potencjalni prosumenci, czyli wszyscy obecni odbiorcy energii elektrycznej, w tym ponad 12 mln odbiorców energii elektrycznej z dominującego segmentu ludnościowego, obejmującego przede wszystkim 6 mln gospodarstw w domach jednorodzinnych, ale również $6 \mathrm{mln}$ mieszkań w budownictwie wielorodzinnym (całe społeczeństwo).

Dalej, jest to cały sektor sektor mikro, małych i średnich przedsiębiorstw (MMSP) (1,9 mln przedsiębiorstw mających udział w PKB wynoszacy łącznie ponad 50\%, rozkładający się na przedsiębiorstwa mikro, małe i średnie następująco: 30\%, 9\% i 11\%, odpowiednio). Ważne jest, że sektor ten, oprócz roli prosumenckiej - w tej roli ma najwyższy (wśród wszystkich segmentów energetyki prosumenckiej) potencjał dyfuzji innowacji przełomowych charakterystycznych dla transformacji energetyki - ma także do wypełnienia kluczową rolę siły napędzającej rynek dóbr inwestycyjnych (urządzeń dla energetyki prosumenckiej) i usług w procesie transformacji energetyki do monizmu elektrycznego (dla skutecznego wypełnienia tej roli sektor potrzebuje rynku wewnętrznego wytworzonego przez monizm elektryczny OZE).

Wreszcie są to samorządy: 1600 gmin wiejskich, 500 gmin wiejsko-miejskich, 400 miast (z Unią Metropolii Polskich obejmującą 12 miast), 314 powiatów (bez miast na prawach powiatu), Górnoślassko-Zagłębiowska Metropolia (obejmująca 41 gmin i miast), 
i na koniec 16 województw. Samorządy oprócz roli prosumenckiej (w obszarze zadań własnych) mają do wypełnienia w transformacji energetyki drugą kluczową rolę, mianowicie jest to rola pomocniczości (subsydiaryzm) względem tych, którzy nie radzą sobie na konkurencyjnym rynku energii elektrycznej, np. względem odbiorców wrażliwych.

Polityczne postawienie na wąskie grupy interesów korporacyjnych w energetyce WEK oznaczałoby kontynuację neokolonialnego kursu na import węgla kamiennego (na rosnąca skalę, od 25\% rozpoczynając), ropy naftowej w całości $(100 \%)$ oraz gazu ziemnego (w dominującym wymiarze $>70 \%$ ), a także neokolonialnego importu dóbr inwestycyjnych dla całej energetyki WEK, w szczególności kapitałochłonnych bloków węglowych (koszt bloku 1000 MW to 6 mld PLN) i ekstremalnie kapitałochłonnych bloków jądrowych (w tym wypadku koszt bloku 1500 MW to 40 mld PLN), jednych i drugich obciażonych ekstremalnie wysokim ryzykiem kosztów osieroconych, wymagajacych systemów pokrycia praktycznie natychmiast po ich uruchomieniu.

Postawienie na wąskie grupy interesów korporacyjnych skutkowałoby dalszym domykaniem pułapki, w którą Polska została wepchnięta polityką odwrotu (2000) od rynkowej reformy elektroenergetyki. Skutkiem jest to, że elektroenergetyka WEK (a wraz z nią cała energetyka WEK) zaczęła się urządzać w pułapce (w kryzysie). Pokazują to podejmowane dramatyczne próby racjonalizowania niespójności ustrojowej polityki (Polityka Energetyczna Polski do 2040 roku - PEP 2040) oraz systemu prawnego w postaci ustawy Prawo energetyczne, ustawy o OZE i ustawy o rynku mocy z ramami 2030 unijnej polityki klimatyczno-energetycznej (do roku 2050) w postaci systemu dyrektyw i rozporządzeń przyjętych w długim procesie przygotowawczym zapoczątkowanym (pod powszechna medialną nazwą Pakiet Zimowy) w roku 2016 i zakończonym w połowie 2019 roku (pod medialną nazwą Czysta Energia dla wszystkich Europejczylków).

Zarówno PEP 2040, jak i cały system prawny wskazuja, że odwrót od rynkowej reformy elektroenergetyki spowodował w polskiej przestrzeni publicznej odbudowę mentalnego zakorzenienia w korporacyjnej (w Polsce socjalistycznej) tradycji elektroenergetyki WEK.

To ostatnie zdania wymaga komentarza. Dialektyka działa, zatem to nowe zakorzenienie jest „progresywne” - niestety w sensie negatywnym. Polityka energetyczna stała się obecnie zdecydowanie bardziej arogancka od socjalistycznej. Establishment znacznie 
pewniejszy siebie. A w społeczeństwie następuje powrót do ucieczki od wolności, jednak rekompensowanej dużą domieszką anarchizmu. W rozpatrywanym kontekście ucieczka od wolności oznacza ucieczkę od przejęcia odpowiedzialności za własną sytuację energetyczna, czyli ucieczkę od wysiłku odpowiedzialności za nią. Anarchizm objawia się natomiast narastaniem żądań coraz obfitszych systemów wsparcia.

Z politycznego punktu widzenia wybór drugiej strony oznacza kurs na odbudowę odpowiedzialności, przekierowanie pieniędzy z importu na inwestycje w kraju, z nieracjonalnych fundamentalnie biurokratycznych systemów wsparcia na budżetowe finansowanie sprawiedliwej transformacji energetyki w ramach dozwolonej pomocy (konkurującej z finasowaniem reform w szkolnictwie i służbie zdrowia). Oznacza także kurs na wydostanie się z pułapki niekompatybilności systemowej (mentalnej) ze środowiskiem unijnym. W praktycznym wymiarze jest to kurs na wydostanie się z pułapki energetyki jądrowej (w której się znalazła Białoruś i zaczyna doświadczać - wraz z dobiegającym do końca procesem uruchamiania pierwszego z dwóch bloków jądrowych 1200 MW każdy - jej dotkliwych skutków).

Wybór drugiej strony oznacza budowę własnego przemysłu i rynku usług potrzebnych transformacji energetyki do monizmu elektrycznego OZE (przemysłu i rynku usług bazujących na przemyśle ICT, który zreszta sam pilnie potrzebuje nowego impulsu rozwojowego - jeśli nie chce dopuścić do załamania się swojej dynamiki rozwojowej trwającej przez ostatnich kilkanaście lat - i jeśli Polska ma się znaleźć w pierwszej połowie nowej dekady w gronie europejskich liderów transformacji cyfrowej).

Dalej, wybór drugiej strony oznacza stworzenie rynku wewnętrznego (obecnie zablokowanego przez energetykę WEK) napędzanego przez monizm elektryczny. Stworzenie rynku wewnętrznego, pobudzające rozwój potrzebnego przemysłu i potrzebnego sektora usług, oznacza zarazem stworzenie jednemu i drugiemu (przemysłowi i rynkowi usług) warunków do zdobycia selektywnych przewag na konkurencyjnym runku transformacji energetycznej (zarówno rynku europejskim jak i rynku globalnym).

\section{Koncepcja (reforma) i program}

Punktem wyjścia do prezentowanej w niniejszym Raporcie ustrojowej reformy rynku energii elektrycznej jest hipoteza robocza, że transformacja polskiej energetyki do monizmu elektrycznego OZE 2050 jest nieuchronna i nie może to być transformacja żywiołowa. 
Dlatego nieuchronna, bo wybór modelu prosumenckiego zaspakajania potrzeb energetycznych politycznie oznacza kurs na budowę, w długim horyzoncie czasowym, klasy średniej, bardzo potrzebnej Polsce (bez niej długoterminowa przyszłość Polski jest we współczesnym świecie zagrożona).

Dlatego też transformacja nie może być żywiołowa, bo w krótkim horyzoncie czasowym koszt żywiołowej transformacji jest nieakceptowalny, zarówno społecznie, jak i - w ustroju demokratycznym - również politycznie; w tym kontekście niebagatelne znaczenie ma fakt, że systemowa transformacja energetyki, wzmacniająca w długim horyzoncie czasowym klasę średnią, jest warunkiem ograniczenia ryzyka rozszerzania się wykluczenia energetycznego mającego przyczynę w kryzysowym wzroście cen energii elektrycznej. A sprawa takiego wzrostu, mająca pierwszą odsłonę w drugiej połowie 2018 roku i tląca się przez cały rok 2019 wróci w dramatycznej wersji już na początku roku 2020.

Współczesne (koniec drugiej dekady XXI wieku) uwarunkowania determinuja jednoznacznie koncepcję ustrojowej reformy energii elektrycznej. Jest to koncepcja (koncentrująca się na regulacjach prawnych zapewniających konkurencję, a nie na dotacjach) ukierunkowująca rynkowa transformację energetyki na monizm elektryczny OZE. Ustrojowa reforma rynku energii elektrycznej jest jedyną realną siłą napędową takiej transformacji (transformacji oznaczającej jej samofinansowanie się, czyli oznaczającej budowę nowej energetyki przez prosumentów i niezależnych inwestorów z sektora MSP, korzystających ze środków własnych, a wspomagająco z nowych produktów rynku kapitałowego).

Program restrukturyzacji starej energetyki (schodzacej) paliw kopalnych (WEK), realizowany głównie za pomocą decyzji właścicielskich, chociaż wspomagany przez mechanizmy rynkowe, wiąże się z odpowiedzialnością będąca domeną państwa/rządu. Istotą dobrego programu transformacji energetyki jest zaproponowanie takiej architektury i takich mechanizmów rynku energii elektrycznej, które będa zdolne absorbować bardzo szybki postęp technologiczny i szybkie zmiany społeczne przy sukcesywnym (dynamicznym) redukowaniu specjalnych regulacji prawnych. To pociaga za soba potrzebę koncepcji tworzącej podstawy pod trwałe regulacje wyprzedzające (sprawcze, rozwojowe), w miejsce dotychczasowych doraźnych regulacji nadążnych, wprowadzanych pod presją kolejnych (małych, ale coraz większych, szybko postępujących) kryzysów. 
Bez regulacji prawnych rynek energii elektrycznej długo jeszcze nie będzie w stanie wypełniać swojego głównego zadania, którym jest racjonalna alokacja zasobów. Ale muszą one (regulacje) respektować nowy fakt: zmianę relacji miedzy polityką energetyczna i konkurencja. Dlatego potrzebne są regulacje energetyczne zgodne z ogólnymi trendami (we współczesnej ekonomii), wywołujące alokację mikroekonomiczną zasobów za pomocą konkurencji, przekształcającą się w trybie procesów zachodzących „od dołu do góry” w makroekonomiczną. Dotychczas było odwrotnie: polityka energetyczna odgórnie wymuszała makroekonomiczną alokację zasobów, a ta dopiero określała mikroekonomiczną konkurencyjność.

Decyzje właścicielskie będące właściwością programu restrukturyzacji są w polskiej energetyce skupione obecnie ( $z$ uwagi na istniejąca strukturę właścicielska) w dominującej części w rękach rządu. To oznacza, że rząd zderzył się, po 20 latach od wejścia (w roku 2000) na drogę recentralizacji i etatyzacji elektroenergetyki, z typowym - dla tego modelu - problemem sanacji masy upadłościowej. Z tą różnica, że arbitrem w tym wypadku nie są sądy. Są (będa) nim grupy interesów przy urnach wyborczych.

W praktyce oznacza to całe społeczeństwo na drodze do upodmiotowienia vs wąskie grupy broniące swoich dotychczasowych interesów polityczno-korporacyjnych. Po stronie społeczeństwa jest to - w szczególności - budząca się na drodze do upodmiotowienia klasa średnia, szukająca swojej szansy w modelu prosumenckiego monizmu elektrycznego OZE. Czyli w modelu aktywizującym w tendencji wszystkich (współczesnych) odbiorców energii elektrycznej. Ponadto dużą część przedsiębiorców sektora MMSP - inwestorów na rynku energii elektrycznej. Jednak przede wszystkim usługodawców - w podstawowym stopniu na rynku usług dla prosumentów zaspakajających swoje potrzeby energetyczne w modelu monizmu elektrycznego OZE, w mniejszym stopniu na samym rynku energii elektrycznej.

\section{Wprowadzenie}

\section{Przyjęta konwencja (jak rozumieć koncepcję, a jak program)}

Sformułowane dotychczas uwagi maja na celu zakomunikowanie czytelnikowi, że wszystkie zapisy koncepcji i programu nie mają siły wiążącej i nie mogą być też trakto- 
wane w kategoriach jakiejkolwiek uzurpacji ze strony autora. W tym kontekście podkreśla się jednak, że dochodzenie, zarówno do koncepcji jak i programu, a także sposób jego upublicznienia mają wiele wspólnego z oddolnymi działaniami w roku 1989 (Jan Popczyk, Stefan Sobieszczański) poprzedzającymi rozpoczęcie ustrojowej reformy elektroenergetyki w roku 1990. Tak jak wówczas chodziło o wsparcie intelektualne środowisk proreformatorskich, tak obecnie chodzi o takie wsparcie dla dynamicznie rozwijających się środowisk pro-transformacyjnych.

Stąd prezentowane w Raporcie koncepcja i program mają status ćwiczenia intelektualnego i działania edukacyjnego; kryteria ćwiczenia intelektualnego spełniają w szczególności Podstany fundamentalne transformacji energetycznej (przedstawione w załącznikach stanowiących „przedłużenie” koncepcji reformy i programu restrukturyzacji).

Z tym łączy się mocno tu podkreślana potrzeba wprowadzenia do przestrzeni publicznej wyraźnego przekazu dotyczącego przełomowego charakteru koniecznych zmian w energetyce. Bez pobudzenia wielkiej debaty społecznej na temat koniecznego zakresu transformacji przełomowej energetyki - za pomocą ustrojowej reformy runku energii elektrycznej - Polska nie wykorzysta swojej historycznej szansy, osunie się natomiast w procesie nowego układania świata co najmniej w sposób trwały na pozycje peryferyjne (zostanie skazana w modelu neokolonialnym na rozwój co najwyżej naśladowczy).

$* * *$

Ponieważ koncepcje prezentowane w Raporcie mają charakter autorski, to autor ponosi za nie pełną odpowiedzialność. Czytelnik natomiast może się z nimi krytycznie zgodzić (krytycznie, czyli wytknąć błędy, rozwinąć), odrzucić (zniszczyć) lub zignorować. Podkreśla się, że waga transformacji energetyki jest tak wielka, że nie daje możliwości pozostawania biernym nikomu, kto się mieni być za nią choć trochę odpowiedzialnym (w praktyce nikomu, kto zabiera w jej sprawie, bądź w sprawach związanych, głos). Każdy, kto odrzuci prezentowane w Raporcie koncepcje powinien podjąć wysiłek przedstawienia własnych, alternatywnych; dotyczy to także tego, kto prezentowane koncepcje zignoruje. Konkurencja koncepcji jest obecnie (pilnie) potrzebna, tak jak konkurencja na rynku energii elektrycznej w nadchodzących latach.

Do programu reformy energetyki stosuje się poniżej następującą umowę, dotycząca jego datowania i statusu. Otóż początek prezentowanego programu nie ma jednoznacznego datowania. Choć jest ono bardzo pożądane, byłoby możliwe tylko wtedy, gdyby 
rząd miał taki program i ogłosił go, wraz z harmonogramem - ta przesłanka jednak nie jest spełniona. Ostry kryzys w elektroenergetyce nakazuje w takiej sytuacji działania na rzecz sformułowania programu w trybie społecznym, eksperckim, innym. Właściwy czas na program w każdym z tych trybów jest sprawą indywidualną.

Wiąże się to z faktem, że elektroenergetyka mimo ostrego kryzysu i braku działań rządu ciagle trwa, a chętnych do włączenia się w przyspieszającą karuzelę kadrową schyłkowego sektora nie brakuje. Opozycja polityczna często nie wykazuje jeszcze zainteresowania reforma, bo na poziomie mentalnym nie jest do niej przygotowana i nie potrafi przekuć fundamentalnych korzyści, których nie rozumie, w bieżącą korzyść polityczna. Wzrost cen energii elektrycznej w sektorze MMSP zaczyna się przekładać na inflację, ale na razie powolna. Z kolei samorządom łatwiej ciągle jeszcze, na ogół, znaleźć sposoby krótkoterminowej amortyzacji tych wzrostów niż przejąć długoterminową inicjatywę w zakresie budowania nowej lokalnej rzeczywistości energetycznej w ramach ustrojowej odpowiedzialności właściwej dla subsydiaryzmu.

Generalnie, zaskakująco duża część interesariuszy, którzy widzą kryzys (i nawet dużo o nim mówia) zaczyna się w tym kryzysie „urządzać”. Dla nich jest jeszcze za wcześnie na inicjatywy prowadzące do działań na rzecz tworzenia programu reformy; generalnie zaś za wcześnie (ze względu na brak kompetencji) na przejście na pozycje beneficjentów monizmu elektrycznego OZE, przede wszystkim jednak na pozycje pretendentów do rynku wschodzącego energii elektrycznej 1.

Jest jednak już drugi biegun. Tych, którzy z poziomu indywidualnych decyzji mikroekonomicznych dostrzegają własne korzyści w transformacji. $\mathrm{Na}$ tym biegunie sa to na razie głównie prosumenci zamieszkujący domy jednorodzinne (beneficjenci nowelizacji ustawy OZE z połowy roku 2016). Na tym biegunie będzie także rosło szybko znaczenie prosumentów z sektora MMSP przyłączonych do sieci nN (potencjalni beneficjenci nowelizacji ustawy OZE z połowy roku 2019), a także tych prosumentów z sektora MMSP, którzy napotykają na coraz większe trudności przyłączeniowe związane z deficytem zdolności przyłączeniowych do sieci SN.

Potencjalnym segmentem o wielkim znaczeniu są w perspektywie bieżącej prosumenci w postaci gospodarstw zamieszkujących mieszkania w budownictwie wielorodzinnym (spółdzielnie mieszkaniowe, wspólnoty mieszkaniowe, osiedla deweloperskie). W tym wypadku potrzebne jest przejście zarządów oraz członków spółdzielni (wspól- 
not) mieszkaniowych oraz deweloperów na pozycje pretendentów do rynku wschodzacego energii elektrycznej 1, do jego segmentu posiadającego dostęp do platformy Operator Informacji Rynku Energii - elektrycznej (OIRE).

Oczywiście, jako pretendenci muszą oni, w kontekście platformy OIRE, przyczynić się do wyegzekwowania od rządu harmonizacji polskiego prawa z unijną dyrektywą dotyczącą wspólnych zasad dla wewnętrznego rynku energii elektrycznej, na początku w trybie nowelizacji ustawy Prawo energetyczne wprowadzającej właściwe rozwiązania (projekt nowelizacji został opracowany, ale nie został skierowany do publicznych konsultacji).

Istotną siłą stają się na drugim biegunie także ci, którym zrozumienie globalnej transformacji energetyki umożliwia dostrzeżenie ich indywidualnego zagrożenia (niewykorzystania szans) z powodu braku reformy energetyki. Tu największą grupą interesariuszy (pretendentów do rynków produktów i usług kierowanych na wschodzący rynek energii elektrycznej 1) oraz na rynek popytowy potrzeb prosumenckich) są już polscy przedsiębiorcy z sektora MMSP (w tym z przemysłu ICT), którzy widza, jak rynek wewnętrzny (krajowy) transformacji energetyki przejmuja przedsiębiorcy zagraniczni.

Mimo, że większość samorządów ogranicza się jeszcze ciagle do krótkoterminowego amortyzowania wzrostu kosztów zakupu energii elektrycznej na potrzeby własne z rynku schodzącego WEK, to jednak szybko rośnie, chociaż z niskiego poziomu, siła samorządów jako pretendentów do wschodzącego rynku energii elektrycznej 1) (działających w długim horyzoncie czasowym), zarówno jako prosumentów (w kontekście zadań własnych), ale przede wszystkim jako odpowiedzialnych za realizację zasady ustrojowej pomocniczości (subsydiaryzmu).

Ujawnia się też trzeci biegun. Są to ci, którzy z racji zawodu odpowiadaja (w wymiarze osobistym) za jakość edukacji energetycznej. Prezentowany w Raporcie program, mający charakter ekspercki (profesorski), został zrealizowany na tym biegunie. Oczywiście, tu nie ma takiego momentu, który byłby niewłaściwy dla opracowania programu transformacji energetyki, a przede wszystkim koncepcji ustrojowej reformy rynku energii elektrycznej. Można nawet stwierdzić, że wraz z upływem czasu potrzeba opracowania programu, jak i koncepcji, jest coraz bardziej nagląca. Dzieje się tak dlatego, że siła kryzysu w elektroenergetyce gwałtownie narasta, a ryzyka związane z potencjalnymi błędnymi rozwiązaniami szybko maleja. Decydują o tym: z jednej strony stabilność megatrendów (w tym wielka dynamika postępu technologicznego), a z drugiej zakończony 
(w połowie roku 2019 ) proces implementacji do unijnego porządku prawnego pakietu Caysta Energia dla wszystkich Europejczyków.

Zatem według przyjętej w Raporcie konwencji zaprezentowany program traktuje się bardzo rozciagliwie. Przede wszystkim, wymaga ona adaptacyjnego trybu wykorzystania programu w dwóch aspektach: czasowym i podmiotowym. Datowanie 2020-2025-20402050 zastosowane w Raporcie jest datowaniem podporządkowanym realizacji kolejnych kamieni milowych, ale całkowita autonomizacja etapów jest niedopuszczalna.

Można zaryzykować hipotezę robocza, że transformacja energetyki jest w sensie ekonomicznym i społecznym procesem $z$ pamięcią. W sensie termodynamicznym natomiast wykazuje podobieństwa do równania stanu, mianowicie: stany końcowy 2050 i początkowy 2019 są niezależne od trajektorii transformacyjnej.

W sensie podmiotowym zaproponowane w Raporcie (autorskie) datowanie jest charakterystyczne dla badań naukowych o charakterze systemowym, wykonywanych przez podmioty naukowe. Mogłoby ono być zastosowane w praktyce rządowej (w UE stało się praktycznie standardem w polityce klimatyczno-energetycznej).

Adaptacja zastosowanego datowania do potrzeb mikroekonomicznych generalnie polega na osadzeniu w nim (w tym datowaniu) indywidualnych strategii prosumenckich; w tym wypadku z natury rzeczy istnieje duża swoboda w wyborze czasu działania. Dodatkowo tę swobodę zwiększa fundamentalna właściwość transformacji energetyki do modelu monizmu elektrycznego OZE: są nią decyzje mikroekonomiczne (indywidualne), układające się w długie czasowe ciąi kolejnych etapów działań (decyzji behawioralnych).

Każdy czytelnik wykorzysta program na swój sposób. Oczywiście bieżąca sytuacja polityczna powoduje, że prezentowany program może być wykorzystany przez nowy rząd. Jest zrozumiałe, że autor Raportu miałby w takim wypadku satysfakcję.

Jednak głównym powodem opracowania Raportu są potrzeby edukacyjne. Pobudzenie działań oddolnych (na poziomie mikroekonomicznym) uznaje się w Raporcie za ważniejsze od polityki energetycznej (będącej rządowym narzędziem makroekonomicznego kształtowania energetycznej rzeczywistości). Edukacja (na poziomie powszechnym i elitarna w uczelniach) jest warunkiem wzrostu oddolnego potencjału dyfuzji innowacji przełomowej w obszar transformacji energetyki, a zarazem wzrostu potencjału 
oddolnego wymuszenia na politykach porządku prawnego przyspieszającego transformację energetyki. Razem te dwa potencjały składowe mają współcześnie potencjał kształtowania nowej makroekonomii (rozumianej ogólnie), i wreszcie, potencjał do spowodowania zmian ustrojowych (razem jest to potencjał zmian cywilizacyjnych).

\section{Ramy prawne (mała i duża unifikacja)}

Potencjał ustawy Prawo energetyczne (1997), nowelizowanej 121 razy, całkowicie się wyczerpał. Koncepcja systemu prawnego zapisanego w tej ustawie (prace nad ustawa rozpoczęły się w roku 1991) była odpowiedzią na ustrojową zasadę dostępu stron trzecich do sieci (Third Party Acces - TPA), której globalny proces wdrażania do elektroenergetyki rozpoczął się w roku 1989 w Wielkiej Brytanii w środowisku ustawy elektrycznej (ustawa The Electricity Act 1989).

Krytyczna analiza różnic między polskim Prawem energetycznym i brytyjską ustawa elektryczna jest przydatna w działaniach na rzecz wypracowania koncepcji systemu prawnego potrzebnego dla polskiej energetyki, właściwego dla jej obecnej kryzysowej sytuacji, oraz globalnego i unijnego środowiska transformacyjnego energetyki. Koncepcja Prawa energetycznego powstawała w Polsce w czasie ustrojowej (politycznej) reformy państwa i była ukierunkowana na „,wpisanie” w tę reformę całej energetyki sieciowej (elektroenergetyki, ale także ciepłownictwa i gazownictwa; sektory górniczy i paliw płynnych był na obrzeżach ustawy z uwagi na ich mniejszą podatność na monopol sieciowy, ale także z uwagi na ogromną siłę polityczna, zwłaszcza górnictwa).

Brytyjski przypadek był zupełnie inny. Ustawa elektryczna miała inne zadanie. W szczególności dlatego, że reforma elektroenergetyki następowała w Wielkiej Brytanii „na końcu” ustrojowej denacjonalizacji gospodarki, po wcześniejszych niezwykle trudnych reformach w innych sektorach energetycznych (strajki w latach 1984-1985 i złamanie historycznej potęgi górnictwa węgla kamiennego, prywatyzacja sektorów naftowego i gazowego w latach 1980-1986). W rezultacie brytyjska ustawa elektryczna miała za zadanie wytworzenie konkurencji na rynku energii elektrycznej w środowisku reformy liberalizacyjno-prywatyzacyjnej elektroenergetyki i na tym się koncentrowała.

Jądrem brytyjskiej ustawy elektrycznej była zasada TPA wdrażana w trzech etapach (rok 1990 - dostęp uzyskali najwięksi odbiorcy, o mocy szczytowej zapotrzebowania powyżej 1 MW, 1994 - dostęp uzyskali odbiorcy o mocy szczytowej zapotrzebowania 
powyżej 100 kW, 1998 - dostęp mieli uzyskać pozostali, najmniejsi odbiorcy; w rzeczywistości proces wdrażania zasady TPA doznał dwuletniego opóźnienia). Ustawa elektryczna miała zatem na celu stworzenie trwałej siły napędowej poprawy efektywności ekonomicznej elektroenergetyki po jej ,jednorazowej” prywatyzacji w trybie reformy (prywatyzacyjnej).

Prawo energetyczne w Polsce miało natomiast na celu stworzenie podstaw pod reformy ustrojowe we wszystkich sektorach energetycznych. W praktyce tylko elektroenergetyka wykorzystała szansę na reformę (w tym odłączenie się od systemu elektroenergetycznego Pokój, funkcjonującego w środowisku RWPG i połączenie z systemem Coordination of Production and Transmission of Electricity - UCPTE Europy Zachodniej). W takiej sytuacji naturalnym było, że rynek energii elektrycznej stał się jądrem Prawa energetycznego.

Uwarunkowania europejskie (1989/1990 - reforma elektroenergetyki brytyjskiej; 1992-1995 - proces przełączania Krajowego Systemu Elektroenergetycznego (KSE) ze „wschodu na „zachód”; 1992-1996 - proces przygotowań i implementacji prawnej pierwszej unijnej dyrektywy - 96/92/WE - dotyczącej jednolitego rynku energii elektrycznej ustanawiającej harmonogram dostępu do sieci dla odbiorców o rocznym zużyciu energii elektrycznej powyżej 9 MWh; 1994 - wejście Polski w tryb akcesyjny UE) spowodowały, że Prawo energetyczne w obszarze rynku energii elektrycznej kształtowało się głównie w trybie dyfuzji najbardziej nowoczesnych rozwiązań brytyjskich i następnie unijnych.

$* * *$

Historyczna analiza ustawy Prawo energetyczne zderzona z realiami roku 2019 dotyczacymi polskiej elektroenergetyki, a z drugiej strony z ustrojem („oprzyrządowaniem”) prawnym unijnych ram (2030) polityki klimatyczno-energetycznej (2050), czyli z pakietem Caysta energia dla wszystkich Europejcaykéw, prowadzi wprost do dwóch ważnych hipotez roboczych. Pierwsza to ta, że Polska - beneficjent europejskich i globalnych reform rynkowych w elektroenergetyce bazujących na zasadzie TPA, zapoczattkowanych reformą brytyjską w roku 1989 - znalazła się w roku 2019 w pułapce mającej w energetyce charakter ustrojowy. Druga natomiast podpowiada ucieczkę do „przodu”. 
Punktem wyjścia do analiz dotyczących obydwu hipotez jest przedstawiony w tab. 1 zarys struktury regulacji prawnych składających się na ramy (rok 2030) polityki klimatyczno-energetycznej.

Tabela 1. Struktura (synteza) regulacji prawnych (2019) składających się na ramy (2030) unijnej polityki klimatyczno-energetycznej (2050)

Ramy (2030) unijnej

polityki klimatyczno-energetycznej (2050)
Cele (2030)

Redukcja $\mathrm{CO}_{2}$

(względem 2005)
Udział Poprawa efektywności energe-

OZE tycznej

\section{Baza (punkt wyjścia)}

Mapa Drogowa (2050) - strategia (2009) ogłoszona przez Komisję Europejską (cel 2050: redukcja gazów cieplarnianych o 80 do 95\% względem 1990, udział źródeł OZE w produkcji energii elektrycznej nie mniejszy niż 97\%)

Pakiet klimatyczno-energetyczny 3x20 (2020) - pakiet regulacji prawnych (2009) obejmujący: Dyrektywę EU ETS, Decyzję non-ETS, Dyrektywę CCS, Dyrektywę OZE

\section{Dyrektywy (2018/19)}

Wspólne zasady rynku energii elektrycznej

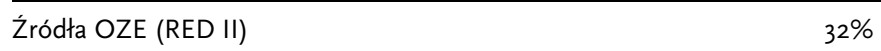

Efektywność energetyczna

$32,5 \%$ oraz energia pierwotna: $E_{p}(2030)<15$ tys. TWh

Charakterystyka energetyczna budynku

Ukierunkowanie (2050) na całkowitą dekarbonizację

Rozporządzenia (2018/19)

Wewnętrzny rynek energii elektrycznej

Gotowość na wypadek zagrożeń

w sektorze energii elektrycznej

Roczne redukcje emisji gazów cieplarnianych

Cel całkowity (2030):

40\% (43\% w systemie

ETS, $30 \%$ w non-ETS)

Agencja ds. Współpracy Organów

Regulacji Energetyki w UE

Zarządzanie unią energetyczną

i działaniami w dziedzinie klimatu

Charakterystyczną właściwością tej struktury jest to, że - na cztery dyrektywy i pięć rozporządzeń - cele 2030 (redukcja $\mathrm{CO}_{2}$, udział OZE, poprawa efektywności energetycznej) są przedmiotem trzech dyrektyw i jednego rozporządzenia. Pozostałe regulacje 
prawne dotyczą głównie (praktycznie tylko) rynku energii elektrycznej. Jest to właściwość potwierdzająca poprawność koncepcji (stanowiącej przedmiot Raportu), bazującej na nazwie „transformacja energetyki do monizmu elektrycznego OZE”, bowiem w tej właśnie koncepcji siłą napędową jest rynek energii elektrycznej.

Zatem od rynku energii elektrycznej (i rynku usług dla energetyki prosumenckiej funkcjonującej w modelu monizmu elektrycznego) będzie zależeć powodzenie polityki klimatycznej. Na obecnym etapie sprowadza się to do realizacji zobowiązań Porozumienia paryskiego (2015). Podkreśla się w tym miejscu, że proces ratyfikacji Porozumienia został zakończony przez Unię w rekordowo krótkim czasie, mianowicie już w październiku 2016 roku. Przy tym nie dlatego, że dotyczy ono sprawy prostej, lecz sprawy niezwykle ważnej.

Znaczenie rynku energii elektrycznej, jako rodzącej się siły napędowej transformacji energetycznej, wzmacnia jeszcze analiza retrospektywna przyjętych w roku 2009 przesłanek pod ramy (2020) unijnej polityki klimatyczno-energetycznej (2050), na które składały się: Mapa Drogowa 2050 oraz trzy dyrektywy i jedna decyzja, patrz tabela 1.

Otóż wówczas (2009) układ sił między „interwencja”” (polityka, wsparciem) i rynkiem był całkowicie odmienny od obecnego. W tamtym układzie sił rynek praktycznie nie istniał, dominowały cele $\mathrm{i}$ „dopasowane” do nich systemy wsparcia. Po dziesięciu latach sytuacja się zmieniła. Za przyczyną rozwoju technologicznego (odbywającego się przede wszystkim pod wpływem rynków wewnętrznych - jednak o globalnym znaczeniu - chronologicznie: unijnego, chińskiego i amerykańskiego) oraz obniżki cen jednostkowych źródeł OZE (i innych dóbr inwestycyjnych, na które zapotrzebowanie wytwarza transformacja energetyki do monizmu elektrycznego OZE), a także za przyczyną wzrostu kompetencji prosumenckich w masowej skali, punkt ciężkości przeniósł się na rozproszony (zdecentralizowany) rynek energii elektrycznej.

W rezultacie przyjęte w roku 2019 ramy (2030) unijnej polityki klimatyczno-energetycznej (2050) odwzorowują dążenie do wytworzenia równowagi między działaniem rynku energii elektrycznej i systemami wsparcia. Wyraźnie na to wskazują zapisy (trzech dyrektyw i jednego rozporządzenia) dotyczące celów przewidzianych do realizacji w ramach (2030). Otóż są to zapisy podkreślające potrzebę analizowania w trakcie realizacji ram (2030) - czyli w nadchodzącej dekadzie - celów w kontekście możliwości ich podwyższenia. Zapisy te należy traktować jako zapowiedź, że główną właściwością kolejnych ram (2040) - które będą przyjmowane w roku 2029 - będzie eliminacja systemów 
wsparcia i koncentracja na rozwiązaniach zapewniających rynkowi energii elektrycznej odporność kryzysowa, czyli zdolność do jego funkcjonowania w wypadku zagrożeń. Takie ukierunkowanie ram (2040) będzie naturalnym rozwinięciem i kontynuacja tego, co w ramach (2030) jest przedmiotem rozporządzenia w sprawie „gotowości na wypadek zagrożeń w sektorze energii elektrycznej”.

Jest to ogólna sytuacja, z którą związana jest druga hipoteza dotyczącą ucieczki Polski do przodu i wydostania się z pułapki. Kryzysowa sytuacja w elektroenergetyce wymaga od Polski zastosowania - bez zwłoki - kryzysowego trybu budowy nowego rynku energii elektrycznej. Jeśli nasz kraj podejmie to wyzwanie, to ruszy naprzód rynkowym kursem prowadzącym do monizmu elektrycznego OZE i nie tylko przestanie być spychany na pozycje trwałej negacji unijnej polityki klimatyczno-energetycznej (na pozycję autsajdera), ale będzie miał szanse nawet wcześniej osiagnać cel, określony w Mapie Drogowej (2050).

Taki rozwój sytuacji znajduje silne uwiarygodnienie w szokowym wzroście energetyki fotowoltanicznej (PV) w roku 2019 (szacunkowy przyrost mocy wyniesie w Polsce ponad $1 \mathrm{GW})$, na pewno w dużym stopniu pobudzonym przez kryzys cenowy z końca roku 2018.

Mapę regulacji prawnych umożliwiających Polsce wyjście z pułapki przedstawia sygnalnie tab. 2. Wszystko w niej jest do „ulepszenia”, a z drugiej strony nie do odrzucenia jest synteza kilku (czterech-sześciu) spraw pryncypialnych. Chodzi o sprawy tworzące środowisko, w którym trzeba osadzić ustrój prawny transformacji energetyki do monizmu elektrycznego OZE, umożliwiający realizację transformację w trybie od reformy do rynku.

Po pierwsze, stan istniejący wskazuje, jak łatwo można było system prawny (pierwsze Prawo energetyczne) przekształcić ze służącego wzmacnianiu efektywności reformy ustrojowej elektroenergetyki w „wytwórnię” problemów blokujących poprawę efektywności elektroenergetyki (poddanej recentralizacji). Czyli pokazuje, co się stało, kiedy prawo musiało „obsługiwać” te grupy interesów, które spowodowały w roku 2000 wielki odwrót od ustrojowych reform zapoczątkowanych po roku 1989. Liczba nowelizacji Prawa energetycznego, a również ustawy OZE (zaledwie 5-letniej) nie pozostawiają pod tym względem wątpliwości. Nie ma zatem również wattpliwości, że nowy etap, transformację energetyki od reformy do rynku, trzeba rozpocząć od stworzeniu (w „ruchu”) minimalnego spójnego zbioru reguł (regulacji prawnych) zwiększających strefę wolności 
rynkowej, ograniczających jednak skutecznie ryzyko samoodtwarzania się pozarynkowych grup interesów. Reguł, które zwiążą ręce rządowi dlatego, że będą one zasadami wyborców, realizujących transformację energetyczną, wykształconych, a nie wyborców tworzących zindoktrynowaną klientelę polityków.

Dlatego po drugie, kryzys w elektroenergetyce pod żadnym pozorem nie może być wykorzystany do ustawowego (za pomoca prawa) gaszenia „pożaru” (w energetyce WEK). Musi być wykorzystany do pobudzenia rozwoju oddolnych kompetencji, i oddolnej aktywności. Potrzebny jest zbiór fundamentalnych reguł, których żadnemu rządowi nie będzie się opłacało naruszyć. Temu służy zbiór pięciu rodzajów działań wyróżnionych w tabeli 2: od kryzysowych aż po unifikację dużą.

Działania te, ich sekwencja - to już po trzecie - są ukierunkowane na stworzenie, przez rząd przymuszony kryzysem, środowiska umożliwiającego masowe decyzje mikroekonomiczne. Sekwencja działań wyszczególnionych w tabeli 2 nie jest przypadkowa. $Z$ jednej strony spełnia ona wymagania upływu czasu, ale $z$ drugiej jest podporządkowana zasadzie maksymalizacji wykorzystania zasobów uśpionych (respektuje też ograniczenia związane z osiagalną dynamiką wzrostu powszechnej świadomości i elitarnych kompetencji).

Po czwarte, określenie „unifikacja” mogłoby w tabeli 2 z powodzeniem być zastapione przez inne, mianowicie „konwergencja”. Na początek, w warunkach deficytu elitarnych kompetencji, byłoby to nawet lepsze określenie, bo jest w nim więcej pierwiastka biernego (konwergencja dokonuje się „sama”). Unifikacja wiąże się natomiast z dochodzeniem do spójności (systemu prawnego) z szerokim otoczeniem poprzez twórczą myśl najlepszych prawników, inżynierów, ekonomistów, socjologów i przyrodników zaangażowanych w transformację energetyki. Inaczej, unifikacja wiąże się z odnajdywaniem w decyzjach indywidualnych (mikroekonomicznych) zasad wspólnych na rynku.

Produktem twórczej myśli, jeśli nie chcemy się zgodzić z podażaniem za trwającym kryzysem w polskiej elektroenergetyce, musi być - to już po piąte - mała unifikacja polegająca na wdrożeniu do systemu prawnego rynku energii elektrycznej zasady TPA+. Ustrojowe znaczenie tej zasady polega przede wszystkim na dekompozycji odpowiedzialności w sferze dotychczas nazywanej bardzo enigmatycznie (wieloznacznie) bezpieczeństwem elektroenergetycznym (energetycznym) na dwie składowe: na odpowiedzialność operatorską operatora systemy przesyłowego OSP oraz operatorów systemów 
dystrybucyjnych OSD i OSDn za bezpieczeństwo KSE oraz „odpowiedzialność” rynku za adekwatność ofert rynkowych (podażowych) w zakresie dostaw energii elektrycznej.

Tabela 2. Synteza ustroju prawnego transformacji energetyki do monizmu elektrycznego OZE: od stanu istniejącego (VIII 2019) do dużej unifikacji w postaci Prawa elektrycznego (2025)

\begin{tabular}{|c|c|c|c|}
\hline $\begin{array}{l}\text { Stan istniejący } \\
\text { VIII } 2019\end{array}$ & $\begin{array}{l}\text { Zbiór regulacji } \\
\text { (działania) }\end{array}$ & Etap X 2019-2020 & Etap 2021-2025 \\
\hline \multirow{4}{*}{$\begin{array}{l}\text { Prawo } \\
\text { energetyczne } \\
-121 \text { nowelizacji } \\
\text { (115 już weszło } \\
\text { w życie, } 6 \text { wejdzie) }\end{array}$} & \multirow{3}{*}{ Kryzysowe } & $\begin{array}{l}\text { Agregaty UGZ uzyskują dostęp do } \\
\text { rynku RB }\end{array}$ & $\begin{array}{l}\text { Wstępna unifikacja taryf dyna- } \\
\text { micznych, bilansowania energii } \\
\text { i regulacji mocy na rynku czasu } \\
\text { rzeczywistego (RCR) }\end{array}$ \\
\hline & & Właściciele mieszkań & \\
\hline & & $\begin{array}{l}\text { W budownictwie wielomieszkanio- } \\
\text { wym uzyskują prawo do jednej } \\
\text { faktury (obejmującej użytkowanie } \\
\text { energii elektrycznej) }\end{array}$ & $\begin{array}{l}\text { Wstępna unifikacja sieci nN } \\
\text { energetyki WEK } \\
\text { oraz prosumenckich instalacji nN }\end{array}$ \\
\hline & Pilotażowe & $\begin{array}{l}\text { Utworzony zostaje zbiór pilotażo- } \\
\text { wych (referencyjnych) wirtualnych } \\
\text { systemów elektroenergetycznych } \\
\text { (WSME) }\end{array}$ & $\begin{array}{l}\text { Wstępna unifikacja opłat siecio- } \\
\text { wych (net metering, roaming elek- } \\
\text { troenergetyczny)w systemach } \\
\text { WSE }\end{array}$ \\
\hline \multirow[t]{5}{*}{$\begin{array}{l}\text { Ustawa OZE } \\
-33 \text { nowelizacje } \\
\text { ( } 27 \text { weszło w życie, } \\
6 \text { wejdzie) } \\
\text { Ustawa } \\
\text { o rynku mocy }\end{array}$} & \multirow{3}{*}{$\begin{array}{l}\text { Rozwojowe } \\
\text { etapowe } \\
\text { (długotermi- } \\
\text { nowe) }\end{array}$} & $\begin{array}{l}\text { Następuje wydzielenie niskonapię- } \\
\text { ciowej strefy bezpieczeństwa KSE } \\
\text { (sieci, urządzenia i usługi) w celu } \\
\text { "ustrojowego" rozdzielenia sieci nN } \\
\text { i SN i przyspieszenia przekształceń } \\
\text { własnościowych operatorów sys- } \\
\text { temy dystrybuacyjnego - OSD }\end{array}$ & $\begin{array}{l}\text { Mała unifikacja projektowania } \\
\text { i użytkowania sieci nN energetyki } \\
\text { WEK oraz prosumenckich } \\
\text { instalacji nN }\end{array}$ \\
\hline & & $\begin{array}{l}\text { STD (następuje dekompozycja odpo- } \\
\text { wiedzialności za bezpieczeństwo: } \\
\text { KSE oraz dostaw energii elektrycznej) }\end{array}$ & $\begin{array}{l}\text { Mała unifikacja wysycenia sieci } \\
\text { nN energetyki WEK oraz prosu- } \\
\text { menckich instalacji nN w pro- } \\
\text { dukty przemysłów ICT i AGD }\end{array}$ \\
\hline & & $\begin{array}{l}\text { OIRE (zapewniony jest dostęp do } \\
\text { platformy pomiarowej rynku RCR) }\end{array}$ & $\begin{array}{l}\text { Mała unifikacja systemu } \\
\text { billingowego rynku RCR }\end{array}$ \\
\hline & \multicolumn{2}{|c|}{ Unifikacja mała -TPA+ (XII.202O) } & Punkt wyjścia do unifikacji dużej \\
\hline & Unifikacja duża & - Prawo elektryczne (2025) & \\
\hline
\end{tabular}

Mała unifikacja prawna w postaci zasady TPA+, obejmująca z jednej strony zasadę ustrojową (dekompozycję odpowiedzialności), a z drugiej dyfuzję dostępnych technologii, przede wszystkim energoelektronicznych (produktów przemysłu ICT, w tym inteligentnego akumulatora) do sieciowego terminala dostępowego (STD) i technologii 
teleinformatycznych na platformę OIRE, musi być z całą pewnością produktem twórczej myśli. Inaczej jest nieosiagalna - na pewno nie dokona się sama. Zwłaszcza, jeśli uwzględnić, że istniejący czas dla jej przeprowadzenia (koniec etapu: listopad 20192020) jest niezwykle krótki, a praktyczne skutki są wielkie, bo prowadzą do fundamentalnej przebudowy opłat sieciowych na rynku wschodzacym 1 energii elektrycznej (do ich wirtualizacji).

Wreszcie, po szóste, podkreśla się, że duża unifikacja prawa (zasygnalizowana w tabeli 2) ma podstawy w równym stopniu w ideach, jak i zdarzeniach.

Krótki komentarz do tego stwierdzenia jest następujący. Unifikacja przybierająca postać Prawa elektrycznego (nie energetycznego), wieńcząca etapy pierwszy (listopad 2019-2020) i drugi (2021-2025), oznaczająca przełom w transformacji energetyki od reformy do rynku - mianowicie przełom następujący: mniej (i coraz mniej) polityki energetycznej (etatyzmu państwowego), więcej (i coraz więcej rynku) - egzemplifikuje triplet paradygmatyczny oraz monizm elektryczny OZE (zdefiniowane przez autora Raportu, wytrzymujące liczne testy poprawności i użyteczności).

Powyższy triplet paradygmatyczny to rezultat syntezy nagromadzonych historycznych wydarzeń. Od odkrycia fundamentalnych praw termodynamiki i elektromagnetyzmu oraz 300-letniej energetyki paliw kopalnych poczynając, poprzez erę cyfryzacji, która rządzi światem już ponad 50 lat, (poprzez) przyspieszający rozwój inżynierii materiałowej dostarczający światu inteligentnych materiałów, na globalizacji egzemplifikującej nową ekonomię i nowe procesy społeczne kończąc. Monizm elektryczny OZE to idea sformułowana na początku procesu transformacyjnego, mająca na celu jego porządkowanie, jego racjonalizację (w bardzo rozległym - również czasowo - środowisku, otoczeniu).

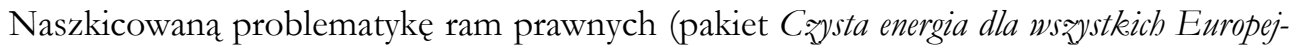
czyyków, tabela 1, oraz synteza ustroju prawnego transformacji energetyki do monizmu elektrycznego OZE, przedstawiona w tabeli 2) należy dopełnić rządowa polityką PEP 2040. Wówczas pojawia się (z punktu widzenia tego, co można i trzeba zrobić w prawie) zaskakująco płodny trójkąt (pierwotny). Na jednym jego wierzchołu jest unijny pakiet Czysta energia dla wssystkich Europejczylkón w postaci dyrektyw i rozporządzeń. Na drugim wierzchołku jest polityka PEP 2040 z Prawem energetycznym, ustawą OZE i ustawą o rynku mocy. Na trzecim - transformacja do monizmu elektrycznego OZE z unifikacja 
prawną w postaci Prawa elektrycznego. W skróconej nazwie jest to trójkąt: „unijny pakiet klimatyczno-energetyczny - polska polityka PEP 2040 - transformacja energetyki do monizmu elektrycznego OZE”.

Trójkąt ten generuje trójkąt sprzężony o następujących wierzchołkach: „cele - polityka/reformy/programy - rynek”; w pierwszym wierzchołku trójkąta sprzężonego lokuje się (używając skróconych nazw trójkąta pierwotnego) polityka PEP 2040, w drugim unijny pakiet klimatyczno-energetyczny, w trzecim transformacja energetyki do monizmu elektrycznego OZE.

Trójkąt sprzężony pozwala wyraźnie dostrzec, że Unia stara się równoważyć cele (polityki klimatyczno-energetycznej), programy (systemy wsparcia) oraz rozwój źródeł OZE i wreszcie (najważniejsze) - działanie rynku energii elektrycznej. Polski rząd ekstrapoluje cele starej polityki energetycznej (nie dając przy tym odpowiedzi, jak je osiągnać, jaki jest powód, aby je realizować wbrew trendom globalnym i unijnej polityce klimatyczno-energetycznej, i wreszcie - nie odpowiadając, dlaczego ze szkodą dla państwa ignoruje szansę pobudzenia gospodarki i przede wszystkim, przebudzenia społeczeństwa). Transformacja energetyki do monizmu elektrycznego OZE polega z kolei na restrukturyzacji właścicielskiej wygaszającej energetykę paliw kopalnych i na reformie rynku energii elektrycznej (na wykreowaniu rynku wschodzącego, zdolnego konkurować z rynkiem schodzącym i całkowicie nowym rynkiem podażowym urządzeń i usług dla energetyki prosumenckiej działającej w modelu monizmu elektrycznego OZE).

Spostrzeżenie związane z trójkątem sprzężonym (trzy ostatnie zdania) podpowiada, że problem występuje na poziomie metod i słowników (czyli na poziomie fundamentalnym). Ponadto, że transformacja energetyki do monizmu elektrycznego OZE (jeden z wierzchołków trójkąta) ma potencjał najskuteczniejszej bazy do unifikacji prawnej wszystkich trzech wierzchołków. Znaczenie tej unifikacji jest nie do przecenienia.

B**
Bez względu na to, jak w Polsce będzie się racjonalizować politykę PEP 2040), sam
fakt jej opracowania i publicznego zaprezentowania jest największym skandalem inte-
lektualno-etycznym w energetyce ostatniego dwudziestolecia. I z całą pewnością trzeba
sobie z nim poradzić. Duża unifikacja prawna (2025), wpisana w środowisko transfor-
macji energetyki do monizmu elektrycznego OZE (tabela 2), jest na to sposobem, do-
stępnym w trybie oddolnym. Interaktywne działania zróżnicowanych środowisk na 
rzecz najpierw małej unifikacji prawnej (zasada TPA+), a następnie dużej (Prawo elektryczne), są w transformacji energetyki do monizmu elektrycznego OZE (zaprezentowanej w Raporcie) głównym sposobem - na początek - pokonania niedostatku intelektualnej kreatywności, w który osunęła się elektroenergetyka po wejściu na drogę recentralizacji w roku 2000.

Z kolei Unia Europejska stała się - co już widać - zakładnikiem Mapy Drogowej (2050) i pierwszych ram (2020) polityki klimatyczno-energetycznej w postaci Pakietu 3x20: mapy pierwotnie niezwykle progresywnej w aspekcie celów, i ram niezwykle niestety przesyconych systemami wsparcia.

Właśnie te systemy (razem z rozrastającymi się biurokratycznymi systemami prawnymi ich stosowania i praktycznie ciagle nienaruszoną ochrona prawną monopolu operatorskiego) powodują, że pierwsze ramy ewidentnie w swojej końcowej fazie blokują transformację energetyki na skutek blokowania dyfuzji postępu technologicznego w obszar rynku energii elektrycznej.

Drugie ramy (2030), chociaż ukierunkowane na konkurencyjny rynek energii elektrycznej (na środowisko energetyki prosumenckiej ze zminimalizowanymi zasobami sieciowymi i zmaksymalizowanymi prosumenckimi zdolnościami regulacyjno-bilansującymi, czyli na środowisko nazywane „obywatelską społecznością energetyczna”), sa jednak ciagle (na razie) we „władzy” systemów wsparcia. Oczywiście, jest ważne, że mają one wmontowane już mechanizmy adaptacyjne, takie jakich nie posiadały pierwsze ramy (2020).

Duża unifikacja prawna (2025), proponowana w środowisku transformacji energetyki do monizmu elektrycznego OZE (tabela 2), pozwala się uwolnić od łatwego samoodtwarzania się grup interesów w energetyce w kolejnych (unijnych) ramach czasowych (2020, 2030, 2040, 2050). Ważne jest, że duża unifikacja prawna (2025) jest zharmonizowana z datami dwóch porządków unijnych. Pierwszy to wymaganie dotyczące pełnego wdrożenia regulacji prawnych ram (2030) już w roku 2026 oraz przeprowadzenie w roku 2027 badań dotyczących realizacji celów przez kraje członkowskie (i ewentualne wdrożenie obowiązujących procedur). Drugi, to zakończenie unijnej perspektywy budżetowej 2021-2027 i konieczność przygotowania się na radykalne ograniczenie wsparcia dla elektroenergetyki w kolejnej perspektywie budżetowej.

Wcale niemałe znaczenie dużej unifikacja prawnej (2025) w Polsce będzie polegać oczywiście (jeśli zostanie, zostałaby zrealizowana) na tym, że umożliwi ona fundamentalne podważenie strategii sojuszu polityczno-korporacyjnego polegającej na totalnej 
opozycji względem prawa unijnego, ale także polegającej na akceptacji dżungli interesów $\mathrm{w}$ istniejacym porządku prawnym (tabela 2).

Do uwidocznionych w tabeli 2 elementów dużej unifikacji prawnej (Prawo elektryczne) na pewno trzeba dodać, jedną dodatkową kategorię. Jest to „bezsieciowy” rynek urządzeń i/lub usług dla energetyki prosumenckiej (2xUEP) - o tym rynku była już w Raporcie wzmianka, ale akronim jest tu zastosowany po raz pierwszy. Ustrojowa waga rynku 2xUEP (jego wprowadzenie do słownika monizmu elektrycznego OZE) ma kluczowe znaczenie, bo pozwoli obniżyć ryzyko nadmiernego zasiedzenia się grup interesów na rynku energii elektrycznej (poprzez wzmocnienie przełomowego charakteru transformacji).

Krótki komentarz do tej hipotezy jest następujący. Ustrojowe znaczenie monizm elektrycznego OZE w Polsce polega nie na tym, że transformuje energetykę paliw kopalnych w rynek energii elektrycznej OZE, ale ponadto w rynek 2xUEP, na którym nie występują ograniczenia natury monopolistycznej (charakterystyczne dla rynku energii elektrycznej). Czyli wprowadzenie rynku 2xUEP do słownika monizmu elektrycznego OZE jest warunkiem płynnego przejścia do konkurencji między rynkami: energii elektrycznej RCR oraz offshoronym i rynkiem 2xUEP.

Dla celów dużej unifikacji prawnej korzystne byłoby podjęcie (jak najszybsze) rozpoznawczych badań symulacyjnych, które umożliwiłyby dobry start do wzajemnej konkurencji trzech wymienionych rynków. W tym kontekście dużą unifikację prawną należy przyrównać do dobrego wyboru punktu startowego w procesie poszukiwania optymalnego rozwiązania w złożonym nieliniowym problemie optymalizacyjnym. I tu od razu też pojawia się problem: czy duża unifikacja prawna jest wrażliwa na segmentację rynku - obszary wiejskie, miasta (z uwzględnieniem ich wielkości), wielki przemysł?

Znalezienie odpowiedzi na to pytanie w ramach modelowych badań rozpoznawczych trajektorii transformacyjnej energetyki (2050) umożliwi jakość dużej unifikacji prawnej zapewniającej fundamentalny wzrost efektywności ekonomicznej rzeczywistego procesu transformacyjnego.

\section{Kamienie milowe (pakiety)}

Na samym początku należy się czytelnikowi wyjaśnienie. Określenie „kamień milowy” jest dalej (cz. Koncepcja i program) stosowane jednolicie w kontekście spójności koncepcji, 
a nie planu operacyjnego. Oczywiście, gdyby całościowy plan operacyjny zbudowany na prezentowanej koncepcji istniał (i stał za nim np. rzą), to kamienie milowe automatycznie podlegałyby przeniesieniu do tego planu.

Zasygnalizowany problem nazewniczy jest czubkiem góry lodowej. Brak nazewnictwa długo będzie bariera postępu w zakresie opisu i realnego postępu transformacji energetyki. Trzeba przy tym zawsze jednak pamiętać, że przedwcześnie „zadekretowane" nazewnictwo jest nie mniej groźne niż jego brak. Aby ten dylemat choćby tylko trochę złagodzić, przedstawia się w tabeli 3 strukturę nazewnictwa pozwalającego obniżyć ryzyko nieprawidłowego rozumienia relacji między (unijna) polityką klimatyczno-energetyczną (2050) i transformacją energetyki do monizmu elektrycznego OZE (2050) za pomoca ustrojowej reformy rynku energii elektrycznej mającej podstawy fundamentalne.

Tabela 3. Struktura słownika do analizy relacji między transformacją energetyki do monizmu elektrycznego OZE (2050) za pomocą ustrojowej reformy rynku energii elektrycznej oraz (unijnej) polityki klimatycznoenergetycznej (2050)

\begin{tabular}{|c|c|c|}
\hline Zadania & $\begin{array}{l}\text { Transformacja energetyki } \\
\text { do monizmu elektrycznego OZE } \\
\text { REFORMA i PROGRAM }\end{array}$ & $\begin{array}{l}\text { Polityka } \\
\text { klimatyczno-energetyczna }\end{array}$ \\
\hline 1 & 2 & 3 \\
\hline \multirow[t]{2}{*}{ Ochrona klimatu } & $(-)$ & 1. Trzy cele \\
\hline & & 2. Systemy wsparcia \\
\hline $\begin{array}{l}\text { Budowa konkurencyjnego } \\
\text { rynku energii elektrycznej }\end{array}$ & $\begin{array}{l}\text { Ustrojowa reforma rynku energii elektrycznej } \\
\text { (ramy prawne por. tabela 2) }\end{array}$ & $\begin{array}{l}\text { 3. Zarządzanie polityką (ramy } \\
\text { realizacyjne: } 2020,2030 \text {, } \\
2040,2050 \text { - por. tabela } 1\end{array}$ \\
\hline $\begin{array}{l}\text { Restrukturyzacja energe- } \\
\text { tyki WEK } \\
\text { (paliw kopalnych) }\end{array}$ & $\begin{array}{l}\text { Restrukturyzacja energetyki WEK (paliw kopalnych) } \\
\text { w trybie decyzji właścicielskich (i ewentualnych } \\
\text { rządowych programów sprawiedliwej transformacji) }\end{array}$ & $(-)$ \\
\hline
\end{tabular}

Konsekwencje tego zabiegu są bardzo poważne. Przy tym Raport ogranicza się do ich naświetlenia tylko w kontekście polskim: nie formułuje „rad” kierowanych do Unii, podpowiada natomiast, jak Polska może przy uwzględnieniu krajowych uwarunkowań wykorzystać na swoją korzyść to, co z fundamentalnych podstaw wynika.

Z drugiej jednak strony, tabela 3 pokazuje (chociaż nie bezpośrednio), że szybko wyczerpuje się potencjał narracji prowadzonej pod hasłem „polityka klimatyczno-ener- 
getyczna”. Mianowicie, neutralność klimatyczna energetyki (energetyka bez paliw kopalnych) staje się bardzo szybko problemem rynkowym, przestaje być problemem politycznym. Dlatego przychodzi czas na zajmowanie się klimatem w inny sposób. Chociaż dalej musi on być sprzężony z polityką, to jednak za pomocą odwróconych relacji skutkowo-przyczynowych, i to w nowych strategicznych obszarach. Może to być np. „,polityka wodna (polityka kształtowania stylu życia, inne) w służbie ochrony klimatu".

Komentarze do pustych pól w tabeli 3, w kolumnach 2 i 3 mają (mimo, że są puste!) dużą wagę.

Otóż, w aspekcie ochrony klimatu (puste pole w kolumnie 2) rynkowa transformacja energetyki do monizmu elektrycznego OZE sama w sobie może być skuteczniejsza (zwłaszcza na obecnym etapie, po praktycznym zakończeniu ram 2020) niż polityka klimatyczno-energetyczna, tzn. może przyspieszyć realizację celów zapisanych w Mapie Drogowej (2050). Doświadczenia z realizacji Pakietu 3x20 nakazują wręcz postawić pytanie, na ile politycy zdali egzamin zasypując brak intelektualnej kreatywności i politycznej odwagi górami (zbyt dużymi) pieniędzy przepuszczonych przez biurokratyczne systemy wsparcia.

Komentarz do pustego pola w kolumnie 3 musi z kolei, z natury rzeczy, koncentrować się na ustrojowych aspektach funkcjonowania Unii. Otóż „pominięcie” (niedostrzeganie) w polityce klimatyczno-energetycznej wielkiego problemu restrukturyzacji energetyki WEK (paliw kopalnych) - oznaczające, że musza go rozwiązać państwa członkowskie indywidualnie - jest unikaniem problemu.

Z drugiej strony, w perspektywie ustrojowej, jest kapitulacją na rzecz podtrzymywania konfederacji (a nawet jej rozluźniania); jest z cała pewnością rezygnacją z pogłębiania unijnej integracji.

Jedno (unikanie problemu) i drugie (kapitulacja, rezygnacja) będzie opóźniać transformację europejskiej energetyki, a potem osłabiać gospodarkę Unii, i napędzać siły odśrodkowe. W wypadku unii energetycznej będzie to oznaczało naśladownictwo unii monetarnej (i strefy euro).

\section{0 - działania kryzysowe (i program restrukturyzacyjny 2050)}

Przez działania kryzysowe rozumie się działania proponowane do podjęcia (a w części, zależnej od okoliczności, do zrealizowania) w etapie październik 2019-2020 przez siły 
oddolne, ponad podziałami politycznymi (indywidualnie, zbiorowo, bez rządu, z rządem). Ten zakres działań jest dalej przedmiotem trójpaku kryzysowego.

Jeśli rząd po wyborach zechce (niezależnie od opcji politycznej) realizować proponowaną transformację energetyki (Reforme i Program), to oczywiście będzie możliwość bardzo dużej intensywności działań, prowadzących do łagodzenia kryzysu. W przeciwnym razie rząd przyspieszy kryzys (wprowadzi energetykę w pętlę dodatniego kryzysowego sprzężenia zwrotnego). Intensywność oddolnych działań będzie wtedy ograniczona, ale wystarczy do pobudzania wzrostu oddolnych kompetencji, ważnych w długiej perspektywie.

Odrębną, względem trójpaku kryzysowego (jednak nie niezależna), jest sprawa koncepcji ustrojowej reformy rynku energii elektrycznej, i są taką sprawą programy restrukturyzacyjne zarysowane w Raporcie w zakresie możliwym do opracowania w etapie październik 2019-2020 oraz do realizacji w postaci kolejnych kamieni milowych (2025, 2040 i 2050). Otóż w samym zamierzeniu są one (koncepcja, programy) jedynie punktem wyjścia do pożądanych konkurencyjnych inicjatyw, w pesymistycznym wariancie tylko oddolnych, w etapie październik 2019-2020.

Konkurencyjne inicjatywy powinny obejmować przede wszystkim krytyczną analizę relacji między podstawami fundamentalnymi na których są zbudowane Reforma i Program w Raporcie, a z drugiej strony podstawami (politycznymi i fundamentalnymi) na których jest zbudowana unijna polityka klimatyczno-energetyczna 2050.

W pierwszym wypadku jest to triplet paradygmatyczny. W rzeczywistości unijnej najbliższy postulatowi podstaw fundamentalnych pod transformację energetyki jest jednolity rynek unijny (w tym jednolity rynek energii elektrycznej); na wyższym poziomie zasadne są odwołania do ustroju politycznego nazwanego tu „Unią obywateli”. Jednak w odniesieniu do budowy nowej energetyki (do budowania neutralności klimatycznej) Unia zachowuje się jak „Unia celowa” - jest niebezpiecznie spychana w tę stronę przez nowe grupy interesów. Zatem występuje odwrócenie „biegunowości”.

Podstawy fundamentalne w postaci tripletu paradygmatycznego przemawiają za tym, aby nową energetykę budować (a do neutralności klimatycznej dochodzić) za pomoca rynku, a restrukturyzację energetyki paliw kopalnych wspomagać polityką celowa (w formule sprawiedliwej transformacji). Unijna polityka klimatyczno-energetyczna jest z kolei polityką celową (nowa energetyka w nadchodzącej dekadzie ciagle jeszcze będzie budowana w ramach takiej polityki), a restrukturyzacja energetyki paliw kopalnych jest 
pozostawiona krajom członkowskim (i rynkowi, przy bardzo ograniczonej dopuszczalności pomocy publicznej). Zasygnalizowane odwrócenie biegunowości na pewno wymaga dalszych pogłębionych krytycznych analiz.

Restrukturyzacja energetyki schodzącej WEK (paliw kopalnych), łącznie z działaniami na rzecz budowy kompetencji potrzebnych transformacji energetyki do monizmu elektrycznego OZE (2050) są poniżej przedmiotem pakietów IV-XI.

Trójpak kryzysowy jest ukierunkowany na stany kryzysowe w systemie elektroenergetycznym, mające obecnie istotny negatywny wpływ na ocenę KSE. Ich podstawowy katalog obejmuje cztery stany: $1^{\circ}$ - deficyt mocy w KSE (operatorski - planowanie „doba przed”, inwestycyjny - długoterminowy) , $2^{\circ}$ - deficyt zdolności przyłączeniowych do sieci SN operatorów OSD na obszarach wiejskich (operatorski, krótkoterminowy - związany z istniejącymi ograniczeniami sieciowymi, ekonomiczny - związany z nieakceptowalnym okresem zwrotu nakładów), $3^{\circ}$ - przerwy w zasilaniu (rozległe awarie sieciowe, awarie sieciowych układów zasilających nN-SN, wyłączenia planowe odbiorców), $4^{\circ}$ - kryzysowy (ponad inflacyjny, np. 5 punktów procentowych większy od wskaźnika inflacji) wzrost cen końcowych energii elektrycznej. Trójpak kryzysowy obejmuje trzy pakiety oddolnych działań, realizowanych sukcesywnie, mających na celu pobudzenie wykorzystania zasobów uśpionych.

Są to:

I pakiet - na ten (mały) pakiet nowelizacji ustawowych (obejmujących sukcesywne, w całym okresie październik 2019-2020, nowelizacje ustawy OZE oraz Prawa energetycznego) składają się regulacje pobudzające wykorzystanie zasobów uśpionych oraz rozwój mikroskalowych („inteligentnych”) zasobów technologicznych (przede wszystkim terminali STD) o bardzo krótkim czasie komercjalizacji i wielkim potencjale dyfuzji do energetyki prosumenckiej, do segmentów: ludnościowego, MMSP, samorządowego oraz do gospodarki rolno-hodowlanej (przede wszystkim na obszarach wiejskich).

Są to regulacje ukierunkowane na rozwiązania systemowe. Zbiór nowelizacji obejmuje w szczególności trzy charakterystyczne obszary regulacyjne. $1^{\circ}$ - opłata sieciowa w postaci dynamicznego net meteringu dla potrzeb układów gwarantowanego zasilania (UCZ) w pierwszej kolejności, a następnie dla potrzeb źródeł PV, korzystających (obecnie) z net meteringu statycznego (współczynnika net meteringu określonego ustawowo), $2^{\circ}$ - rozwiązanie „1 faktura” dla gospodarstwa domowego w budownictwie wielorodzinnym (spółdzielnie i wspólnoty mieszkaniowe, osiedla deweloperskie), $3^{\circ}$ - wymagalność wyposażenia obiektu technologicznego w gospodarce rolno-hodowlanej (kurnik, obora, chlewnia, przetwórnia rolno-spożywcza itp) w instalację w postaci mikroelektrowni utylizacyjnej).

Ponadto I pakiet obejmuje specyficzne regulacje prawne, „sprzężone” z trzema charakterystycznymi, przedstawionymi powyżej). Są to regulacje mające na celu pobudzenie działań o charakterze pilotażowym 
(takich regulacji w energetyce dotychczas praktycznie się nie stosowało). Działania pilotażowe mają na celu pozyskanie doświadczeń dla potrzeb super unifikacji (rynku wschodzącego 1) obejmującej szczególne rozwiązania (z cechami wirtualnymi charakterystycznymi dla uogólnionego systemu WSE), takie jak klaster energii, czy spółdzielnia energetyczna (rozwiązania istniejące już w systemie prawnym), a także takie jak elektrownia wirtualna i inne (rozwiązania potencjalne).

II pakiet - jest to pakiet działań (projektów) pilotażowych realizowanych z wykorzystaniem regulacji prawnych tworzących I pakiet. Zasady kształtowania projektów pilotażowych uwzględniają stronę podmiotową systemów WSE (tak jak to jest w wypadku istniejących już w systemie prawnym klastrów energii i spółdzielni energetycznych), jednak „rozluźniają” kryterium uczestnictwa poprzez jego „odwrócenie”: na platformę WSE może wejść każdy podmiot, który nie ma zakazu prawnego wejścia. Z drugiej strony, zasady kształtowania projektów pilotażowych koncentrują się przede wszystkim na stworzeniu poligonów rozwoju mechanizmów (rozwiązań) rynkowych na uogólnionej platformie WSE oraz rozwoju usług i urządzeń (infrastruktury biznesowo-technologicznej) na tej platformie.

Zatem aktywizują całkowicie nowe grupy pretendentów do rynku wschodzącego ı. Odbiorców posiadających układy UGZ o mocach jednostkowych od kilkuset kW do kilku MW pobudzają do partycypacji (przy wykorzystaniu dynamicznego net meteringu) w rynku bilansującym RB, będącym na razie wyłączną właściwością operatora OSP. Spółdzielnie oraz wspólnoty mieszkaniowe i deweloperów (osiedla deweloperskie) mobilizują do zwiększania potencjału dyfuzji rozwiązania „, faktura” (jest to zarazem mobilizacja do podwyższania kompetencji zarządów i członków spółdzielni, wspólnot, osiedli deweloperskich i do budowania kapitału społecznego, w środowisku stanowiącym połowę polskiego społeczeństwa).

Najważniejszą sprawą w II pakiecie (działań pilotażowych) jest oczywiście pobudzenie rozwoju infrastruktury biznesowo-technologicznej w postaci sieci terminali STD oraz platformy pomiarowej OIRE, czyli stworzenie podstaw: najpierw pod unifikację prawną małą (III pakiet, zasada TPA+, koniec 2020 r.) i dużą (Prawo elektryczne, 2025), a dalej pod super unifikację rynku wschodzącego 1 (2030).

III pakiet - jest to mała unifikacja prawna kończąca trójpak kryzysowy (bazująca na doświadczeniach wynikających z jego realizacji). Znaczenie unifikacji do postaci zasady TPA+ w trybie nowelizacji (koniec 2020) ustawy Prawo energetyczne polega na tym, że uruchamia ona (w „cieniu” konkurencji między rynkiem wschodzącym 1 oraz schodzącym WEK) dwa bezsieciowe rynki 2xUEP (urządzeń i usług energetyki prosumeckiej), które dopełniają cechę przełomowości transformacji energetyki do monizmu elektrycznego OZE, związaną z kryterium wymagającym zastąpienia starego rynku nowym, o radykalnie odmiennym charakterze. Rynki 2xUEP kryterium to spełniają. Praktyczne znaczenie tych rynków polega na tym, że rozszerzają 
one środowisko potencjalnych pretendentów, zdolnych absorbować przełomowe innowacje biznesowotechnologiczne, a ignorować podmioty zasiedziałe na rynku schodzącym 1.

Wynikiem małej unifikacji prawnej, bazującej na koncepcji terminala STD umożliwiającego dekompozycję bezpieczeństwa elektroenergetycznego, jest unifikacja technologiczna prosumenckich instalacji wewnętrznych oraz operatorskich sieci nN i unifikacja zasad bezpieczeństwa elektrycznego w tym obszarze.

Pakiet koncepcyjno-restrukturyzacyjny rynku offshorowego jest tożsamy z pakietem rynku wschodzącego 2 energii elektrycznej. Pakiet ten obejmuje dwa obszary (zagadnienia). Pierwszym są zasoby offshorowe obejmujące podstawowo morskie farmy wiatrowe na Morzu Bałtyckim (ale także potencjalne skandynawskie zasoby magazynowe (dominujące znaczenie mają w tym wypadku zasoby norweskie, około 120 TWh), a także podmorskie sieci kablowe DC. To zagadnienie ma w przypadku polskiej transformacji energetycznej praktycznie tylko wymiar biznesowy. Podkreśla się przy tym, że w tym wymiarze mieszczą się mechanizmy rynkowe (na rynku wschodzącym 2); zagadnienia pozabiznesowe - takie jak koncepcje technologiczne, rozwój technologii - są już poza zasięgiem dostępnym Polsce).

Drugim zagadnieniem są lądowe układy dosyłowe sięgające aż do rynku wschodzącego 1 (do osłony OK4, po stronie $110 \mathrm{kV}$ ). To zagadnienie tworzy najbardziej hermetyczny (specjalistyczny) pakiet rozwojowo-restrukturyzacyjny całej polskiej transformacji energetycznej do monizmu elektrycznego OZE, zdominowany przez bardzo specjalistyczną tematykę techniczną. W tym wypadku kluczowe znaczenie ma koncepcja systemowo-technologiczna lądowych układów dosyłowych, które będą się kształtować na szkielecie obecnej sieci przesyłowej KSE 400-220-110 kV w procesie jej restrukturyzacji w długoterminowym horyzoncie czasowym, ściśle powiązanym z wygaszaniem rynku schodzącego WEK, głównie wielkoskalowych źródeł węglowych. Część systemowa koncepcji będzie wynikiem konkurencji między rynkiem wschodzącym 2 oraz rynkami: schodzącym WEK i wschodzącym 1. Część technologiczna koncepcji będzie w dużym stopniu powstawać w procesie naśladownictwa rozwiązań globalnych w obszarze rozwiązań hybrydowych DC-AC (chińska dominacja know-how w tym zakresie jest już nie do podważenia).

IV pakiet - obejmuje opracowanie koncepcji (i strategii) dostosowania sieci 400-220-110 kV do potrzeb przyłączenia układu dosyłowego energii elektrycznej pochodzącej z pierwszych farm offshore (2024-2025) do korytarza infrastrukturalno-urbanistycznego północ-południe pn. „kotwica” (korytarz obejmujący najsilniejszy ciąg liniowy 400-220 kV między elektrowniami szczytowo-pompowymi Żarnowiec oraz Żar-Porąbka, aglomeracje od Trójmiasta poprzez Warszawę, Łódź, Górnośląsko-Zagłębiowską Metropolię, Kraków i Wrocław oraz dominującą część przemysłu ciężkiego petrochemicznego, górniczego, hutniczego i chemicz- 
nego). Dalszy rozwój rynku wschodzącego 2 (czyli już po wdrożeniu koncepcji w zakresie dotyczącym pierwszych farm offshore) musi odbywać się pod wpływem konkurencji (przy zminimalizowanym wpływie koncepcji-polityki energetycznej).

Ze względu na specyfikę (odpowiedzialność prawną oraz skalę trudności technicznych) IV pakiet w części dotyczącej najpierw opracowania koncepcji, a następnie jej wdrożenia w dominującym zakresie, musi być zrealizowany przez operatora OSP. W tym pakiecie partycypacja oddolna jest możliwa jedynie w niewielkiej części, ale jest. W szczególności jest możliwa partycypacja przez sektor organizacji pozarządowych (NCO - w tym specjalistyczne prywatne fundacje) i staranny dobór tematów ekspertyz realizowanych na styku koncepcji układów technicznych, zagadnień ekonomicznych, regulacji prawnych oraz zagadnień środowiskowych (przyrodniczych) i społecznych.

Czteropak wygaszania energetyki paliw kopalnych obejmuje także odstąpienie od programu energetyki jądrowej. Jest to czteropak działań sprowadzających się generalnie do „zastąpienia” polityki PEP 2040 programem restrukturyzacji całej energetyki WEK (elektroenergetyki, górnictwa, gazownictwa i paliw płynnych). Jako taki jest właściwością rządu (należy do jego kompetencji). Na tej ścieżce powinien być ogłoszony jako rządowy program. W trybie oddolnym może natomiast być realizowany przez sektor NGO, podobnie jak w przypadku pakietu IV, jednak przy znacznie większym udziale, co wynika z nabytych już (w ostatnich kilkunastu latach) kompetencji sektora NCO w tematyce charakterystycznej dla czteropaku. Specyfika działań wchodzących w zakres czteropaku umożliwia już skuteczną realizację strategii oddolnej polegającej na wykorzystaniu synergii sektora NGO oraz niezależnych ekspertów: synergii dużej zdolności sektora NGO do wywierania publicznej presji na rząd oraz kompetencji niezależnych ekspertów (prywatnych fundacji, prywatnych firm).

$\mathrm{Na}$ czteropak składają się:

V pakiet - opracowanie programu restrukturyzacji inwestycji węglowych Ostrołęka i Turów, odstąpienie od programu budowy odkrywki węgla brunatnego Złoczew i program restrukturyzacji Elektrowni Bełchatów, odstąpienie od programu energetyki jądrowej. (Jeśli rząd opracuje i ogłosi programu, to oddolne działania będą ukierunkowane na współpracę. W przeciwnym wypadku oddolne działania muszą mieć, uwzględniając fazę kryzysu, w którą weszła już polska energetyka, charakter społecznych działań obronnych).

VI pakiet - rozpoczęcie wdrażania strategii wygaszenia elektrowni węglowych na węgiel kamienny w horyzoncie 2040, ogłoszenie strategii restrukturyzacji aktywów sektora górnictwa węgla kamiennego (koksownictwo, ewentualne wykorzystanie węgla kamiennego do przetwórstwa chemicznego). 
VII pakiet - ogłoszenie strategii restrukturyzacji aktywów sektora gazowego i paliw płynnych w horyzoncie 2050.

VIII pakiet - wprowadzenie do statutu operatora OSP odpowiedzialności za koordynację programów restrukturyzacyjnych (wygaszania) energetyki WEK (paliw kopalnych) na drodze do monizmu elektrycznego OZE 2050.

Trójpak kompetencyjno-edukacyjny jest (na pewno powinien być) odpowiedzią na potrzebę systemowej przebudowy kompetencji związaną z transformacją energetyki do monizmu elektrycznego OZE. Deficyt kompetencji, którego skutkiem jest głęboki kryzys w energetyce i który stał się już groźną barierą postępu w jej transformacji nie zostanie pokonany bez dobrej ich (kompetencji) strukturyzacji. Stawia się w związku z tym hipotezę, że konieczna i bardzo pilna jest segmentacja obejmująca trzy główne segmenty kompetencyjne: „podtrzymania”, „restrukturyzacji”, „budowania”. Tylko to pozwala wyjść z pułapki, w której znalazła się energetyka: „wszyscy zajmują się wszystkim, poglądy wystarczają (wiedza i doświadczenie nie są potrzebne) do wypowiadania się w każdym obszarze, podejmowania decyzji w każdej sprawie". Podkreśla się, że z drugiej strony pułapka jest środowiskiem urządzania się grup interesów, starych i nowych).

Celem segmentu podtrzymania (kompetencji) w energetyce WEK (czteropak wygaszania energetyki paliw kopalnych) jest „wydzielenie” i ochrona istniejących („eksploatacyjnych”) kompetencji, potrzebnych do sprawnego funkcjonowania istniejących zasobów WEK (w elektroenergetyce nastąpiło już dramatyczne załamanie się kadrowe, które grozi szybszym wycofywaniem istniejących zasobów niżby to wynikało z ich kondycji technicznej i z ich ekonomicznej racjonalności). Zarządzanie segmentem podtrzymania (kompetencji), zwłaszcza w elektroenergetyce, musi być ukierunkowane na pokonanie bariery, którą będzie silny deficyt (współcześnie) chętnych pracowników (na stanowiska wymagające dużego doświadczenia i wysokich kwalifikacji), jednak z góry skazanych na brak perspektyw rozwojowych w miejscu pracy.

Segment kompetencji restrukturyzacyjnych na obecnym etapie musi być ukierunkowany, zwłaszcza w elektroenergetyce, na postępowania likwidacyjne i upadłościowe, bo czas na strukturalną przebudowę biznesową elektroenergetyki WEK już minął. W tym segmencie (pokrywającym się z czteropakiem wygaszania energetyki paliw kopalnych) decydującą rolę mają właściciele przedsiębiorstw tworzących energetykę WEK (w Polsce jest to w dominującej części państwo) oraz państwo występujące w roli autora i egzekutora polityki energetycznej. Partycypacja oddolna w segmencie kompetencji restrukturyzacyjnych ma ograniczone znaczenie, ale jest bardzo pożądana, i jest możliwa (bardziej niż w IV pakiecie) - poprzez partycypację sektora NGO i specjalistyczne ekspertyzy niezależnych ekspertów (czyli w sposób podobny do tego, który jest charakterystyczny dla IV pakietu. 
Segment budowania kompetencji jest ukierunkowany na monizm elektryczny OZE. Segment ten obejmuje w szczególności kompetencje potrzebne do budowanie rynków wschodzących 1 i 2 oraz rynków 2xUEP. Kompetencje w tym zakresie są kompetencjami podstawowymi (rozwojowymi, długofalowymi). Muszą one być budowane w trybie edukacji powszechnej (w szkole podstawowej). Dalej w ramach szkolnictwa zawodowego, przynajmniej na dwóch poziomach: średnim i wyższym (inżynierskim). Wreszcie na poziomie elitarnym (doktorskim).

Potrzebna przebudowa, w trybie interaktywnym, kompetencji w procesie transformacji energetyki do monizmu elektrycznego OZE jest przedmiotem pakietów IX-XI; tryb interaktywny oznacza respektowanie dynamizmu relacji (w pętlach sprzężeń zwrotnych) między (rosnącym) poziomem kompetencji oraz jakością i dynamizm transformacji.

IX pakiet - powołanie (przez rząd) Centrum Badań Strategicznych i Monitorowania Transformacji Energetyki do Monizmu Elektrycznego OZE 2050 (nazwa jest sprawą otwartą; zastosowana pełna nazwa opisowa musi być zastąpiona nazwą własną). Sposób działania Centrum jest wzorowany na sposobie działania Rady Polityki Pieniężnej. Jednak Centrum musi mieć zdecydowanie bardziej rozbudowaną część dedykowaną strategicznym badaniom operacyjnym w obszarze całej transformacji energetyki do monizmu elektrycznego OZE.

X pakiet - oddolne (przy niewielkim wsparciu państwa) działania na rzecz budowy powszechnych (publicznych) kompetencji w obszarze transformacji energetyki do monizmu elektrycznego OZE. Działania te polegają na kształtowaniu kompetencji w trybie zacieśniającej się współpracy sektora NGO oraz niezależnych ekspertów (fundacji prywatnych, firm prywatnych) i szeroko rozumianego kapitału społecznego. Kompetencje charakterystyczne dla X pakietu mają kluczowe znaczenie, bo są możliwe do budowania bez zwłoki (praktycznie natychmiastowo), ich budowa ma najmniejsze koszty transakcyjne (albo kosztów tych nie ma wcale), mają największy potencjał interdyscyplinarności (i zarazem podejścia holistycznego). Przy tym potencjał tych kompetencji w pierwszych fazach transformacji energetyki jest z natury rzeczy duży w obszarze restrukturyzacji energetyki paliw kopalnych (przede wszystkim węglowej). W późniejszych fazach istnieje potencjał rozwojowy w obszarze budowania monizmu elektrycznego OZE.

XI pakiet - ogłoszenie (przez rząd) programu edukacji do monizmu elektrycznego OZE 2050 (budowy kompetencji użytkowych w zakresie transformacji polskiej energetyki do monizmu elektrycznego OZE 2050, zarówno powszechnych jak i elitarnych. W pierwszym wypadku (kompetencji powszechnych) kluczowe jest przede wszystkim sformułowanie rekomendacji dotyczących podstaw programowych kształcenia 
zawodowego na poziomie średnim, jak i wyższym (inżynierskim). W drugim wypadku (kompetencji elitarnych) kluczowe jest wprowadzenie monizmu elektrycznego OZE do szkół doktorskich, ale także (stopniowe) do wykazu dziedzin i dyscyplin naukowych (nowy wykaz dziedzin i dyscyplin - rozporządzenie Ministra Nauki i Szkolnictwa Wyższego, wrzesień 2018 - całkowicie ignoruje cywilizacyjny wymiar transformacji energetyki w badaniach naukowych, w czasie kiedy na świecie jest to już flagowa tematyka wyższych uczelni i instytutów badawczych liczonych w tysiącach).

Do przedstawionych powyżej jedenastu pakietów dołącza się tu siedem komentarzy. Ich celem jest wzmocnienie (uwiarygodnienie) spójności wszystkich przekazów. Ponadto, ze względu na przeważający praktyczny charakter zagadnień będących przedmiotem komentarzy, wyłącza się je z załączników, tym samym z podstaw fundamentalnych, gdzie mogłyby wprawdzie być umieszczone, ale budziłoby to wattpliwości.

Komentarz 1. Realizacja działań pilotażowych, wymienionych w II pakiecie, bazujących na pilotażowym (selektywnym) wykorzystaniu koncepcji zasady TPA+ (jeszcze przed jej wprowadzeniem do powszechnie obowiązującego porządku prawnego), definiującej na nowo dostęp do sieci nN-SN wymaga uchwalenia (przejściowego, małego) pakietu regulacji prawnych na rynku energii elektrycznej (I pakiet). Pod względem formalnym wymagane zmiany regulacyjne można uznać jako korektorskie. Z drugiej strony, sa to zmiany mające znaczenie ustrojowe na rynku energii elektrycznej, bo otwierające jawna (otwarta) konkurencję między: $1^{\circ}$ - zasobami sieciowymi nN-SN energetyki WEK, wykorzystywanymi na rynku wschodzącym 1 energii elektrycznej, $2^{\circ}$ - tradycyjnymi (należącymi do energetyki WEK) zasobami wytwórczymi i zasobami w obszarze usług systemowych KSE, $3^{\circ}$ - nowymi zasobami wytwórczymi OZE (źródłami z wymuszoną produkcja jak i źródłami wytwórczo-bilansującymi) na rynku wschodzącym $1,4^{\circ}$ - nowymi (autoprosumenckimi) zasobami bilansującymi (na rynku wschodzącym 1).

Komentarz 2. Znaczenie praktyczne II pakietu w kontekście pobudzenia zasobów uśpionych można scharakteryzować za pomocą dwóch wybranych przykładów. Pierwszym z nich sa układy gwarantowanego zasilania (UGZ) u co najmniej kilku tys. odbiorców (przyłączonych głównie do sieci SN). Mają one łączną moc około 2000 MW. Przy tym w optyce obecnego rynku bilansującego RB (w optyce operatora OSP, KSE) są one 
obecnie całkowicie ignorowane (niedostrzegane). $\mathrm{Z}$ drugiej jednak strony mają one fundamentalne znaczenie z punktu widzenia super unifikacji rynku wschodzącego 1 energii elektrycznej (Komentarz 1). Drugim przykładem jest budownictwo wielorodzinne (spółdzielnie i wspólnoty mieszkaniowe, osiedla deweloperskie), w tendencji chodzi o uaktywnienie $6 \mathrm{mln}$ odbiorców i zredukowanie $6 \mathrm{mln}$ umów o dostawę energii elektrycznej do 125-450 tys., taki przedział wynika z faktu, że w Polsce jest około 4,5 tys. spółdzielni mieszkaniowych, 120 tys. wspólnot oraz 450 tys. budynków wielorodzinnych). Te liczby nie pozostawiają wattpliwości odnośnie znaczenie budownictwa wielorodzinnego dla rozwoju rynku wschodzącego 1.

Komentarz 3. Szczególne znaczenie koncepcyjne trójpaku kryzysowego polega na tym, że obejmuje on regulacje i rozwiązania umożliwiające stworzenie w trybie poligonów wdrożeniowych uogólnionego rozwiązania biznesowego typu WSE (wirtualny system elektroenergetyczny). To rozwiązanie, w postaci „archipelagu” systemów WSE ma potencjał potrzebny do tego, aby przekształcać się w sposób ewolucyjny (samoistnie) w horyzoncie 2025 w rynek wschodzacy 1). Podkreśla się, że w środowisku trójpaku kryzysowego zbiór rozwiązań biznesowych typu WSE jest zbiorem otwartym. Wyjściowo zbiór ten tworzą takie zakorzenione już mocno rozwiązania jak: elektrownia wirtualna, klaster energii, spółdzielnia energetyczna. Nowym wielkim obszarem domagającym się rozwiązania sa w tym kontekście spółdzielnie mieszkaniowe (wspólnoty, osiedla deweloperskie). Jednak rozwiązania szczególne nie mogą być mnożone. Przeciwnie, potrzebna jest (w horyzoncie 2025) unifikacja rozwiązań do jednolitego rynku wschodzącego 1. Temu służy koncepcja poligonów. Realizacja koncepcji ma stworzyć podstawy pod unifikację.

Komentarz 4. Specjalne znaczenie w restrukturyzacji kryzysowej 2020 ma jednak harmonogram wdrożeniowy zasady TPA + łączącej ściśle pakiet I z pakietem II, który z kolei jest punktem wyjścia do działań w ramach pakietu III. W takim ujęciu charakterystyczne są dla zasady TPA + trzy główne działania wdrożeniowe. Sa to: $1^{\circ}$ - określenie (wyselekcjonowanie) do końca roku 2019 zbioru rozwiązań (poligonów) pilotażowych, $2^{\circ}$ - sukcesywne kumulowanie, do końca roku 2020, doświadczeń pochodzących z poligonów pilotażowych celem stworzenia bazy wiedzy potrzebnej do pełnego ukształto- 
wania zasady TPA+, $3^{\circ}$ - uchwalenie ustawy TPA+, z czasem wejścia w życie od 1 stycznia 2021 roku, pociagające za sobą automatyczną zmianę statusu poligonów pilotażowych w rozwiązania funkcjonujące na podstawie ustawy TPA+.

Pierwsze działanie jest adresowane (w trybie konkursowym) do szerokiego zbioru interesariuszy, w szczególności do klastrów energii certyfikowanych w dwóch pierwszych konkursach przeprowadzonych przez Ministerstwo Energii w roku 2018, ale jeszcze bardziej do spółdzielni energetycznych na obszarach wiejskich „powołanych” przez znowelizowaną ustawę OZE, nowelizacja ustawy z lipca 2019 roku). Jest to działanie realizowane na podstawie rozporządzenia właściwego ministra. Rozporządzenie zapewnia środowisko (zbiór poligonów pilotażowych i obowiązujące w nich zasady) do praktycznego ukształtowania zasady TPA + w takich aspektach jak: certyfikacja terminalu STD (odpowiednio: fizycznego/węzłowego w wypadku prosumentów oraz wirtualnego/algorytmicznego w wypadku platform handlowych), zakres funkcjonalności platformy pomiarów i rozliczeń OIRE, unifikacja rynku bilansującego RB będącego właściwością operatora OSP i taryf dynamicznych na rynku RCR.

Drugie działanie, to wykorzystanie, sukcesywne, doświadczeń dostarczanych przez poligony pilotażowe do pełnej harmonizacji zasady TPA + z całym systemem prawnym dotyczącym rynku energii elektrycznej. To działanie stanowi nową jakość w zakresie stanowienia prawa na potrzeby transformacji energetyki. Polega ona na wyprzedzającej praktycznej weryfikacji (w trybie pilotażowym) rozwiązań materialnych przewidzianych do ogólnego stosowania na podstawie regulacji prawnych. Jej potrzeba wynika ze złożoności (i dynamiki), oraz znaczenia gospodarczego nowych rozwiązań materialnych, a $z$ drugiej strony z ryzyka obciążającego te rozwiązania (ich słabego początkowego rozpoznania, a równocześnie ich wymaganej długoterminowej stabilności).

Trzecie działanie to sukcesywne tworzenie środowiska prawnego zasady TPA+. $Z$ tego punktu widzenia najwyższy priorytet ma zapis regulujacy zasady dostępu podmiotów tworzących system WSE (Komentarz 3) do sieci nN-SN i opłat za ten dostęp. Zapis ten trzeba łączyć z restrukturyzacją operatorów OSD. Mianowicie polegającą na nadaniu sieciom nN-SN statusu odrębnego biznesu, umożliwiającego prawne wydzielenie jego kosztów. Drugi priorytet ma zapis dotyczący dostępu do rynku bilansującego operatora OSP. (Ten zapis nie nastręcza jednak istotnych trudności. Mianowicie wystarczy, że zostanie on zunifikowany z obowiązującymi już unijnymi rozwiązaniami doty- 
czącymi rynku bilansującego). Zasada TPA+ nie obejmuje natomiast (na obecnym etapie) dostępu do marginesu mocy wytwórczych na rynku schodzącym. Pociaga to za soba poważne konsekwencje praktyczne. Mianowicie, blokuje przenoszenie na rynek wschodzący 1) kosztów runku mocy.

Komentarz 5. Opłaty sieciowe na rynku wschodzącym 1) energii elektrycznej (powiązane $z$ restrukturyzacją biznesową operatorów OSD) trzeba rozpatrywać w kontekście dyfuzji innowacji przełomowych na rynek RCR. Ponadto w kontekście podmiotów które korzystaja z zasady TPA+, czyli pełnego zbioru podmiotów tworzących system WSE, a więc: prosumentów (wszystkich: ludność, samorządy realizujące zadania własne, przedsiębiorcy sektora MMSP), ale także inwestorów z sektora MSP inwestujących w elektrownie wirtualne. Kluczowe sa z punktu widzenia zasady TPA+ dwa (obowiązujące rozłącznie) systemy opłat za dostęp do sieci nN-SN (a szerzej do systemu KSE), mianowicie net metering oraz roaming energetyczny (patrz defincje). Te dwa systemy określają dwa różne mechanizmy konkurencji, o podstawowym znaczeniu z punktu widzenia rynkowego kształtowania trajektorii transformacyjnej energetyki. Pierwszy jest głównym mechanizmem konkurencji między rynkiem schodzącym WEK i rynkiem RCR. Drugi natomiast jest fundamentem konkurencji na rynku RCR między: $1^{\circ}-$ sieciami nN-SN, $2^{\circ}$ - gospodarką prosumencką obejmująca źródła wytwórcze oraz zasoby bilansujące prosumentów przyłączonych do sieci nN-SN, wreszcie $3^{\circ}$ - źródłami wytwórczymi i zasobami bilansującymi (stacjonarnymi, przyłączonymi do sieci nN-SN oraz mobilnymi) należącymi do inwestorów z sektora MSP.

Komentarz 6. Działania kryzysowe obejmujące pakiety I-XI mają na celu postawienie tamy kryzysowi w elektroenergetyce, ale jednocześnie powinny chronić system prawny przed jego degradacją za pomocą regulacji wybiórczych, podporządkowanych nowym grupom interesów, i wreszcie powinny zapewniać spójność działań bieżących oraz celów strategicznych: ustrojowej reformy rynku energii elektrycznej i restrukturyzacji energetyki paliw kopalnych.

Stąd wynika zastosowany poniżej sposób zsyntetyzowania działań składających się na kamień milowy 2020. Według tego sposobu kamień milowy tworzy następujący minimalny enumeratywny opis: $1^{\circ}$ - trójpak kryzysowy obejmujący nowelizacje prawne dostosowawcze (cząstkowe, I pakiet), działania pilotażowe (wdrożeniowe, II pakiet) 
oraz wprowadzenie zasady TPA+ w trybie nowelizacji ustawy Prawo energetyczne (mała unifikacja prawna, III pakiet), $2^{\circ}$ - stworzenie praktycznych podstaw pod realizację koncepcji rynku wschodzącego 2) energii elektrycznej (rynek offshore) i ich upublicznienie (IV pakiet), $3^{\circ}$ - czteropak programów restrukturyzacji energetyki paliw kopalnych (oraz odstapienia od programu budowy energetyki jądrowej), i upublicznienie tych programów, obejmujący: podjęcie decyzji restrukturyzacyjnych dotyczących inwestycji w toku oraz decyzji o odstapieniu od inwestycji planowanych (szybkie decyzje, V pakiet), ogłoszenie decyzji o wygaszeniu segmentu węglowych źródeł wytwórczych energii elektrycznej w horyzoncie 2040 (VI pakiet), ogłoszenie strategii restrukturyzacji aktywów sektora gazowego i paliw płynnych w horyzoncie 2050 (VII pakiet) i wprowadzenie do statutu operatora OSP odpowiedzialności za koordynację programów restrukturyzacyjnych (wygaszania) energetyki paliw kopalnych (VIII pakiet), $4^{\circ}$ - trójpak budowy kompetencji na który składają się: utworzenie strategicznego centrum rządowego (IX pakiet), budowa kompetencji oddolnych w środowisku sektora NGO i prywatnego sektora niezależnych ekspertów (X pakiet), budowa kompetencji w ramach powszechnego systemu edukacji (IX pakiet).

Zderzenie przedstawionej syntezy zadaniowej (niezwykle rozległej) z bardzo specjalistycznymi systemami technicznymi (terminal STD, platforma OIRE) oraz drastycznie różniącymi się regulacjami prawnymi (prostymi szczegółowymi - I pakiet i specjalistyczną technicznie a zarazem fundamentalną ustrojowo zasadą TPA+, III pakiet) nie jest błędem metodycznym, jest natomiast z cała pewnością wielkim wyzwaniem dla ludzi posiadających specyficzne zdolności analityczno-syntetyczne (indukcyjno-dedukcyjne).

Komentarz 7. W tym ostatnim komentarzu podkreśla się, że wszystkie unifikacje eksponowane w Raporcie sa w gruncie rzeczy postawieniem za każdym razem sprawy sekwencji przyczynowo skutkowej w postaci: pierwszeństwa regulacji prawnych lub pierwszeństwa rozwoju technologicznego. Pierwszeństwo regulacji prawnych („,wyprzedzajacych”) ma na celu wywołanie za ich pomoca postępu technologicznego i zmian społecznych (jest to przypadek charakterystyczny dla amerykańskiej myśli prawniczej w energetyce). Pierwszeństwo rozwoju technologicznego oznacza, że transformacja energetyczna jest blokowana przez prawo, o jej postępie decydują natomiast wynalazcy. W tym wypadku prawo degraduje się do sankcjonowania interesów podmiotów zasiedziałych na rynku. Jest to przypadek ciagle jeszcze charakterystyczny dla europejskiej 
praktyki prawniczej. Przy tym pakiet Czysta Energia dla każdego Europejczyka niesie z sobą symptomy zmiany tej praktyki.

2025 - ustrojowa reforma rynku energii elektrycznej (wersja alpha rynku wschodzącego 1 oraz pierwszy układ offshore na rynku wschodzącym 2)

Rynek końcowy energii elektrycznej z regulowanymi taryfami w obecnej postaci i w obecnej kryzysowej sytuacji polskiej elektroenergetyki jest bez wątpienia - niezależnie od tego, jak się go próbuje objaśniać - wstydem, z którym trzeba sobie poradzić. Dlatego potrzebna jest ustrojowa reforma rynku energii elektrycznej, której nadaje się postać kamienia milowego 2025 obejmującego wdrożenie wersji alpha rynku wschodzącego energii elektrycznej 1 oraz realizację pierwszego projektu (farmy) offshore.

Ustrojowa reforma rynku energii elektrycznej ma na celu wyeliminowanie - w trzech perspektywach: 2025 (wdrożenie wersji alpha rynku wschodzącego energii elektrycznej 1), 2027 (zakończenie unijnej perspektywy budżetowej rozpoczynającej się w roku 2021) oraz 2030 (zakończenie ram unijnej polityki klimatyczno-energetycznej rozpoczynajacych się też w roku 2021) - systemów wsparcia przy jednoczesnym zapewnieniu rynkowych dostaw energii elektrycznej.

Lista strat spowodowanych patologicznymi systemami wsparcia „sklejonymi” z recentralizacją elektroenergetyki rozpoczęta w roku 2000 i eliminacja jakichkolwiek działań na rzecz wdrożenia konkurencji na rynek końcowy energii elektrycznej w obszarze sieci nN-SN jest długa. Najdrastyczniejsze dwa przykłady zwiąane z systemami wsparcia dla źródeł OZE kształtowanymi w szczególności w okresie 2005-2010 - perspektywa budżetowa 2007-2013, pierwsze unijne ramy (2020) polityki klimatyczno-energetycznej - wiążą się ze wsparciem dla współspalania oraz dla wielkich elektrowni wodnych. Systemy te spowodowały, że wydanie (w okresie 2005-2010) 15 mld PLN na źródła OZE nie doprowadziło do wykreowania żadnej polskiej specjalności technologicznej w obszarze OZE (za to tylko w roku 2011 współspalanie pochłonęło 2 mld PLN, a elektrownie wodne 1 mld PLN).

Niestety, rok 2019 też przynosi przykłady nieracjonalności. „Wielkim” przykładem jest nieracjonalny system wsparcia rynku mocy, który pociaga za sobą ryzyko kosztów osieroconych, i będzie hamował transformację energetyki do monizmu elektrycznego. Nieracjonalnością „przebija” go jednak system wsparcia w postaci dopłaty 5 tys. PLN 
do źródła PV (które absolutnie tej dopłaty nie potrzebuje), ale już nie dla niezwykle potrzebnego na rynku wschodzącym 1 akumulatora prosumenckiego, mającego wielki potencjał technologii pobudzającej rozwój segmentu usług systemowych na tym rynku (rynku wschodzącym 1).

Cztery podstawowe pakiety działań w etapie 2021-2025, związane z ustrojowa reformą rynku energii elektrycznej, przedstawia się poniżej jedynie w bardzo oszczędnej (hasłowej) postaci. Są to pakiety następujące.

I pakiet - wykorzystanie przez operatorów sieci SN-nN dynamicznego net meteringu do unifikacji rynku bilansującego i taryf dynamicznych po rok 2020.

II pakiet - uchwalenie (2025) dużego pakietu regulacji prawnych dla polskiego rynku energii elektrycznej (koherentnego z regulacjami prawnymi pakietu Czysta Energia dla wszystkich Europejczyków), w tym zastąpienie ustawy Prawo energetyczne (w części dotyczącej elektroenergetyki), ustawy OZE i innych (według właściwości) nową ustawą Prawo rynku energii elektrycznej (w skrócie Prawo elektryczne), a ponadto ustawą o dostawach paliw oraz energii elektrycznej (zastępującą obecne URE urzędem „antymonopolowym", dedykowanym obszarowi dostaw paliw i energii elektrycznej).

III pakiet - wdrożenie do końca 2025 osadzonej w Prawie elektrycznym wersji alpha - syntetyzującej segmentowe rozwiązania wdrażane do $2025 \mathrm{w}$ trybie pilotażowym - konkurencyjnego rynku energii elektrycznej (rynek wschodzący 1)), z lokalnym bilansowaniem bazującym na net meteringu oraz z handlem ponad siecią bazującym na opłacie sieciowej w modelu roamingu elektroenergetycznego.

IV pakiet - uruchomienie dostaw energii elektrycznej na rynku wschodzącym 2 z pierwszego projektu (farmy) offshore. (Stawia się hipotezę, że funkcjonowanie w pełni dojrzałego - w postaci wersji beta - rynku energii elektrycznej, obejmującego rynki wschodzące 1 i 2, będzie rzeczywistością w 2030).

2040 - wygaszenie produkcji elektrowni węglowych (ponad 95\% w stosunku do bazy 2019)

Wielkich kosztów osieroconych w elektroenergetyce węglowej nie da się już uniknąć. Nieodwołalnie przyszedł czas zapłaty za „,sukces” największego placu budowy bloków węglowych w Europie, będącego bezpośrednim skutkiem recentralizacji elektroenergetyki zapoczątkowanym w roku 2000 (chodzi o plac w drugiej połowie kończącej się 
dekady obejmujący bloki wytwórcze na węgiel kamienny o mocy ponad $5 \mathrm{GW}$ i nakłady inwestycyjne przekraczajace $30 \mathrm{mld}$ PLN).

Dla zmniejszenia tych kosztów trzeba zastosować radykalne odwrócenie roli bloków węglowych w KSE, bazujące na poszanowaniu ekonomii rynkowej; jest to jedyny sposób redukcji strat gospodarczych (skutków makroekonomicznych przeinwestowania mocy wytwórczych w schyłkowych technologiach i ich nieskoordynowania z zasobami wydobywczymi, zarówno w górnictwie węgla kamiennego jak i brunatnego).

Odwrócenie roli oznacza, że elektroenergetyka węglowa musi od zaraz zaczać dostosowywać się do rynku wschodzącego 1) energii elektrycznej oraz do market coupling na połączeniach transgranicznych. Rynek bilansujący KSE trzeba szybko przenosić na rynki wschodzące: od zaraz i bardzo szybko na rynek 1), a po roku 2025 stopniowo także na rynek wschodzący 2).

Szybkie wygaszenie energetyki węglowej musi być potraktowane przez Polskę jako działanie na rzecz obrony bezpieczeństwa energetycznego (w jego obecnym zrozumieniu). O tym, że w żadnym wypadku nie może ono być traktowane jako czynnik zagrażający temu bezpieczeństwu, decyduje gwałtowne wygasanie kompetencji w energetyce węglowej, i to nie tylko w Europie; ważniejsze jest w tym wypadku wygasanie cywilizacyjne (globalne). Wygasania tego nie da się już zahamować, dlatego podtrzymywanie energetyki węglowej jako zasobu chroniącego bezpieczeństwo energetyczne jest pozbawione racjonalności (jest irracjonalne).

Mogłoby się wydawać, że regulacja dotycząca układów gwarantowanego zasilania (UGZ), zderzona z wygaszaniem energetyki węglowej, ma bardzo ograniczone znaczenie (łączna moc układów UGZ to ok. 2 GW). Sprawa wygląda jednak biegunowo odmiennie, jeśli rozpatruje się ją w kontekście potencjału, jaki stanowią spalinowe agregaty prądotwórcze (mobilne) z jednostkami napędowymi będącymi pochodnymi silników samochodowych. Tu ważne jest najbardziej elementarne spostrzeżenie, że w ciagu 30 lat (od reformy ustrojowej państwa w roku 1989) liczba samochodów osobowych (nie wchodząc w wielki rynek transportu samochodowego) zwiększyła się o ponad $15 \mathrm{mln}$, a łączną moc zainstalowanych w nich silników można szacować na ponad $1000 \mathrm{GW}$; jest to zatem moc przekraczająca około 30 razy moc wszystkich bloków węglowych w KSE.

Porównanie kosztów jednostkowych wygląa równie szokująco: koszt $1 \mathrm{~kW}$ mocy w bloku węglowym wynosi około 6 tys. PLN, a w samochodzie można szacować ten 
koszt na 100 PLN. Oczywiście, występuje tu jeszcze czynnik normujący w postaci resursu technicznego, który w wypadku bloku węglowego osiaga nawet wartość 300 tys. godzin, a w wypadku silnika dieslowskiego jest to szacunkowo 10 tys. godzin. Zatem gdyby uznać, że koszty jednostkowe po unormowaniu nie są dramatycznie różne, to współcześnie rozstrzygający jest czas moralny życia (czas do zepsucia „moralnego”).

Wykorzystanie resursu technicznego bloku węglowego pociaga współcześnie, w środowisku transformacji energetyki do monizmu elektrycznego OZE, czas życia przekraczający 100 lat. To musi kończyć każdą poważną dyskusję dotyczącą sensowności budowy bloków węglowych (znacznie bardziej jeszcze dotyczy to bezsensowności budowy bloków jądrowych).

Cztery podstawowe pakiety działań w etapie 2021-2040 w obszarze wygaszania energetyki węglowej w Polsce są następujące:

I pakiet - zobowiązanie PSE do ogłoszenia harmonogramu wygaszającego, w kontekście KSE, elektroenergetykę węgla brunatnego (Zagłębie Turoszowskie, Zagłębie Bełchatowskie).

II pakiet - zobowiązanie PSE do ogłoszenia harmonogramu wygaszającego, w kontekście KSE, bloki na węgiel kamienny: kondensacyjne klasy 120, 200, 360, $500 \mathrm{MW}$; kogeneracyjne; nowe bloki kondensacyjne klasy 450 MW (Łagisza), 1000 MW (Kozienice, 2xOpole, Jaworzno III).

III pakiet - zobowiązanie grup elektroenergetycznych (PGE, Tauron, Enea, Energa) do ogłoszenia: $1^{\circ}-$ strategii restrukturyzacyjnych swoich segmentów energetyki węglowej (wytwarzania energii elektrycznej i górnictwa: zarówno węgla brunatnego jak i kamiennego - w ostatnim wypadku przy udziale większościowym w takich aktywach) na rynku schodzącym energii elektrycznej, $2^{\circ}$ - strategii rozwojowych na rynku wschodzącym energii elektrycznej 2 (rynek offshore).

IV pakiet - zobowiązanie: $1^{\circ}$ - Polskiej Grupy Córniczej do ogłoszenia swojej strategii restrukturyzacyjnej, $2^{\circ}$ - Jastrzębskiej Spółki Węglowej do ogłoszenia swojej strategii restrukturyzacyjnej w segmencie węgla energetycznego (bez koksowego). 
2050 - transformacja rynkowa do monizmu elektrycznego OZE 2050 (ponad 95\% w stosunku do bazy 2019, rola Centrum Badań Strategicznych)

Transformacja energetyki do monizmu elektrycznego OZE 2050 jest siłą napędową najsilniejszej fali innowacyjności ze wszystkich, które można dotychczas powiązać z energetyką (silniejszą nawet od pierwszej związanej z maszyną parową i górnictwem XVIII wieku oraz druga w postaci fali motoryzacyjno-elektryfikacyjnej - przełom XIX i XX wieku). Dlatego musi być poddana starannie dobranym i zaprojektowanym procedurom ostrożnościowym.

Podstawowe działania związane $\mathrm{z}$ wygaszeniem energetyki paliw kopalnych w horyzoncie 2050 za pomocą ustrojowej reformy rynku energii elektrycznej, sygnalizujące zbiór potrzebnych procedur ostrożnościowych, przedstawia się poniżej jedynie w bardzo zredukowanej (hasłowej) postaci sześciu pakietów. Są to następujące pakiety:

I pakiet - sukcesywna weryfikacja nadążno-wyprzedzająca poprawności mechanizmów rynku energii elektrycznej w kontekście transformacji energetyki do monizmu elektrycznego OZE 2050, zwłaszcza w kontekście elektryfikacji ciepłownictwa i elektryfikacji transportu.

II pakiet - sukcesywne monitorowanie nowych koncepcji i technologii energetycznych dla potrzeb korygowania trajektorii transformacyjnej energetyki, zwłaszcza w kontekście reelektryfikacji OZE.

III pakiet - sukcesywne wypracowywanie rekomendacji odnośnie restrukturyzacji przemysłów górniczohutniczego oraz chemicznego w kontekście działania zreformowanego rynku energii elektrycznej.

IV pakiet - sukcesywne wypracowywanie rekomendacje odnośnie transformacji przemysłów: materiałów budowlanych, maszynowego, ICT, AGD i innych do przemysłu 4.0 w kontekście działania rynku energii elektrycznej.

V pakiet - sukcesywne wypracowywanie rekomendacji odnośnie rozwoju rolnictwa energetycznego w kontekście bezpieczeństwa żywnościowego.

VI pakiet - sukcesywne wypracowywanie rekomendacji odnośnie kształtowania gospodarki obiegu zamkniętego i zasobów surowcowych. 


\section{Monizm elektryczny OZE 2050 - program ponad podziałami}

Potrzeba nadania transformacji energetycznej do monizmu elektrycznego OZE 2050 statusu programu politycznego ponad podziałami wynika z czterech nierozłącznych celów (politycznych, społecznych, gospodarczych), wymagających konsolidacji (kompatybilizacji, unifikacji) transformacji energetycznej w perspektywie od bieżącej do długoterminowej, sięgającej horyzontu 2050.

Pierwszym celem, najbardziej ogólnym (politycznym), jest wykorzystanie historycznej szansy włączenia się Polski poprzez transformację energetyczną (w horyzoncie 2050) w konkurencję o nowy ład cywilizacyjny (o przyrodniczo zrównoważony rozwój gospodarczy, o efektywność gospodarczą budowaną na powszechnej zdolności do dyfuzji narastającej fali innowacji przełomowych, o ład ustrojowy budowany na kapitale społecznym).

Drugim celem, gospodarczym (bieżącym 2020, średnioterminowym 2025-2030 i długoterminowym 2050), jest nagląca, a także ustabilizowana przyszłościowa potrzeba poprawy struktury PKB (w którym udział importu paliw kopalnych, dóbr inwestycyjnych dla energetyki WEK i samej energii elektrycznej wynosi w Polsce około 3\%) - ogólniej natomiast potrzeba przekształcenia energetyki będącej obecnie czynnikiem egzogenicznym rozwoju makroekonomicznego w czynnik endogeniczny (czyli potrzeba wykorzystania transformacji energetyki w trybie poligonu budowy powszechnych kompetencji charakterystycznych dla monizmu elektrycznego OZE).

Trzecim celem, polityczno-gospodarczym (bardzo pilnym), jest zbudowanie zdolności koalicyjnej Polski w wyścigu o środki unijne w perspektywie budżetowej 2021-2027, jednak nie w celu mnożenia „polskich” systemów wsparcia ukierunkowanych na opóźnianie transformacji energetyki WEK (w tym zakresie Polska nie znajdzie już w UE sojuszników), a przeciwnie - na tworzenie polskich zdolności unifikacji wsparcia w trzech obszarach mających priorytetowe znaczenie dla UE decydujących o unowocześnieniu Polski, którymi są: transformacja energetyki do monizmu elektrycznego OZE 2050, wygaszanie polityki WPR (wspólna polityka rolna) oraz budowa gospodarki obiegu zamkniętego.

Czwartym celem, ponownie politycznym (przy tym przede wszystkim bieżącym 2020 i średnioterminowym 2025-2030), jest potrzeba unifikacji polityki sprawiedliwej transformacji pracowniczej w (całej) energetyce schodzącej (paliw kopalnych) i odbiorców wrażliwych na rynku energii elektrycznej oraz programów aktywizacji odbiorców biernych dotkniętych ryzykiem wykluczenia (narażonych na wykluczenie) na rynku energii elektrycznej po jego ustrojowej reformie; czwarty cel musi obejmować także reedukację kadr kierowniczych energetyki WEK (jest to zadanie trudne, bo długo nie będą one akceptować tripletu paradygmatycznego transformacji energetyki). 
Czynnikiem przemawiającym za nadaniem transformacji energetycznej do monizmu elektrycznego OZE 2050 statusu programu politycznego ponad podziałami jest wyjątkowa prostota, jednoznaczność i wielka skalowalność modeli tej transformacji. Ta prostota i jednoznaczność są ważne szczególnie w kontekście powszechnej percepcji całej rzeczywistości energetycznej: odnoszącej się do poziomu grup interesów politycznokorporacyjnych w obecnej energetyce WEK (poziom makroekonomiczny) oraz rozpatrywanej w kontekście nowych interesów grupowych charakterystycznych dla monizmu elektrycznego OZE 2050 (na poziomie mikroekonomicznym).

Na poziomie makroekonomicznym najbardziej przejrzystym przykładem jest oszacowanie wpływu importu paliw kopalnych (potrzebnych energetyce WEK) oraz samej energii elektrycznej na kształtowanie się krajowego PKB. Bardzo proste oszacowanie dla roku 2019 (wykonane wiarygodnie, z wykorzystaniem łatwo weryfikowalnych danych) pokazuje, że koszt tego importu wynosi około 60 mld PLN (w tym koszcie nie ma naturalnie podatków i nie ma krajowych kosztów całej, super wielkiej, infrastruktury do obsługi importu). W podziale na poszczególne pozycje koszty wynosza: ropa naftowa - 40 mld PLN (26 mln ton, koszt jednostkowy 150 PLN/MWh), gaz ziemny - 10 mld PLN (15 mld m³, koszt jednostkowy 60 PLN/MWh - uśredniony koszt gazu sieciowego i LNG), węgiel kamienny - 5 mld PLN (20 mln ton, koszt jednostkowy 35 PLN/MWh), energia elektryczna - 3 mld PLN (10 TWh, koszt jednostkowy 300 PLN/MWh - uśredniony z rynków RDN i RB). Przedstawione oszacowanie kosztów importu 2019 jest spójne z oszacowaniem kosztów zaspokojenia potrzeb energetycznych w roku 2019 wynoszących 200 mld PLN.

O wpływie importu dóbr inwestycyjnych potrzebnych energetyce WEK na kształtowanie się krajowego PKB w perspektywie 2050 i w środowisku polityki PEP 2040 w decydującym stopniu stanowi energetyka jądrowa. Uwzględniając górny wariant tej energetyki zapisany w PEP 2040 (6 bloków po 1500 MW każdy), cenę jednostkową bloku jądrowego 6,5 tys. €/MW, krajowy udział w kosztach inwestycji nie większy niż $20 \%$ oraz czas trwania kontraktu różnicowego wynoszący nawet 30 lat otrzymuje się roczna spłatę kapitałowa po zakończeniu inwestycji (2040) równą w cenach stałych około 7 mld PLN (około 0,35\% obecnego PKB).

Na poziomie mikroekonomicznym takim przykładem jest oszacowanie charakterystyczne dla prosumenckiego modelu transformacji energetycznej domu jednorodzinnego do modelu monizmu elektrycznego OZE. 
W największym uproszczeniu wyjściowe (2018) roczne reprezentatywne (dom z roku 1930, termomodernizacja I generacji - rok 1996, powierzchnia użytkowa $100 \mathrm{~m}^{2}$, dom zamieszkuja 2 osoby) zapotrzebowanie energetyczne ma postać: energia elektryczna - 2,5 MWh, gaz ziemny (ogrzewanie, produkcja ciepłej wody użytkowej) - 34 MWh, benzyna 10 MWh. Koszt pokrycia zapotrzebowania (z podatkiem VAT) wynosi 15 tys. PLN (energia elektryczna -2 tys. PLN, gaz -8 tys. PLN, benzyna -5 tys. PLN).

Transformacja do monizmu elektrycznego OZE zmienia zapotrzebowanie na około 8,5 MWh energii elektrycznej ze źródła OZE (do oszacowania wykorzystano wspó1czynniki transformacyjne z tab. 6, mające pełne pokrycie praktyczne). Do pokrycia zapotrzebowania potrzebna jest (przy obowiązującym współczynniku net meteringu wynoszącym 0,8) roczna produkcja w źródle PV wynosząca około 10 MWh. Roczny koszt energii (przy rynkowych nakładach inwestycyjnych na źródło, zainstalowane bez wsparcia), gwarantujaccy zwrot kapitału, wynosi około 3,5 tys. PLN, czyli jest ponad 4-krotnie niższy od kosztu przed transformacja.

Podkreśla się jednak, że przedstawione oszacowanie uwzględnia pełne nakłady inwestycyjne potrzebne na transformację tylko w części dotyczącej reelektryfikacji OZE. Nie uwzględnia natomiast pasywizacji budynku, elektryfikacji ogrzewania i produkcji ciepłej wody użytkowej oraz elektryfikacji transportu.

Oszacowania dla pełnej transformacji sa zdecydowanie bardzo korzystne, zapewniają koszt po transformacji znacznie niższy niż przed transformacją chociaż otwartą sprawą jest, czy na obecnym etapie (2019) jest niższy o 50\%, czy ,tylko” o 20\%.

Oczywiście, pozostaje jeszcze sprawa bardzo korzystnego działania cen krańcowych w procesie transformacji do monizmu elektrycznego OZE. W konkretnym wypadku, domu jednorodzinnego) bardzo racjonalny wariant polega na „odłożeniu” w czasie elektryfikacji transportu (odłożenie w czasie pasywizacji budynku oraz elektryfikacji ogrzewania i produkcji ciepłej wody użytkowej nie jest racjonalne). Dla tego wariantu koszt po transformacji jest niższy o ponad 50\% (źródło PV jest dobrane do potrzeb produkcji rocznej wynoszącej około $7 \mathrm{MWh}$ ).

Przedstawione oszacowania - makro- i mikroekonomiczne - pokazuja dobitnie, na poziomie powszechnej percepcji, że transformacja energetyczna do monizmu elektrycznego OZE przekształciła się już w platformę zderzającą dwie rzeczywistości. 
Pierwsza jest, symbolicznie, polityka PEP 2040 blokująca transformację. W tej rzeczywistości korzyści małych grup interesów korporacyjnych (indywidualni interesariusze liczeni w tysiącach), pociagaja za sobą straty wielkich grup prosumenckich i sektora MMSP (indywidualni interesariusze liczeni w milionach) na poziomie mikroekonomicznym, bez szans na jakąkolwiek kompensatę tych strat z poziomu makroekonomicznego.

Druga rzeczywistość, to transformacja do monizmu elektrycznego OZE zapewniająca korzyści (na poziomie mikroekonomicznym) grup interesów (indywidualni pretendenci liczeni w milionach); oczywiście, korzyści te umożliwiaja sfinansowanie (z poziomu makroekonomicznego, w ramach redystrybucji wtórnej) reedukację dotychczas elitarnych kadr kierowniczych energetyki WEK (ogólnie sfinansowanie całego programu sprawiedliwej transformacji). 


\section{Załączniki}

\section{Słownik Raportu}

Słownik obejmuje objaśnienia (rozszerzenia) do nazw, którym w niniejszym Raporcie przypisuje się ścisłe (precyzyjne) znaczenie, a są słowami powszechnymi albo składają się $\mathrm{z}$ takich. Zatem słownik nadający tym nazwom jednoznaczne rozumienie jest podstawa prawidłowego rozumienia treści zawartych w Raporcie. Zastosowanie formuły słownika ma dodatkowo na celu wyostrzenie problemu, którym jest dotkliwy deficyt nazewnictwa dotyczącego problematyki transformacyjnej energetyki. Deficyt ten staje się już podstawową bariera postępu w opisie transformacji. W takim kontekście deficyt nazewnictwa jest na obecnym etapie groźny zarówno dla dynamiki, jak i głębokości potrzebnego powszechnego zakorzenienia transformacji. Oczywiście, dynamikę będzie osłabiał. Ale co ważniejsze, będzie transformację niebezpiecznie spłycał (nie pozwoli na szerokie zakorzenienie się prawdziwej głębokości transformacji przełomowej). Tym samym ograniczy jej (transformacji) ozdrowieńcze działanie i wywoła pozarynkowe kryzysy korekcyjne.

Zarówno ze względów metodycznych, jak i dydaktycznych, słownik ogranicza się do zbioru minimalnego nazw, który jest ważny dla prawidłowego opisu transformacji przez badaczy (brzytwa Ockhama). Ale jest także ważny dla czytelnika (ukierunkowuje jego uwagę na problemy węzłowe transformacji i broni przed snuciem domysłów odnośnie znaczenia podkładanego pod poszczególne nazwy, co utrudnia koncentrację na istocie transformacji).

\begin{tabular}{ll}
\hline & Program transformacji energetyki. \\
Program & $\begin{array}{l}\text { Wersja pełna: program transformacji energetyki (do monizmu elektrycznego OZE 2050) } \\
\text { z ustrojową reformą rynku energii elektrycznej i programem restrukturyzacji energetyki } \\
\text { WEK (paliw kopalnych). }\end{array}$ \\
\hline \multirow{2}{*}{ Reforma } & $\begin{array}{l}\text { Ustrojowa reforma rynku energii elektrycznej. } \\
\text { Wersja pełna: ustrojowa reforma rynku energii elektrycznej (zapewniająca transformację ener- } \\
\text { getyki do monizmu elektrycznego OZE) i program restrukturyzacji energetyki wek (paliw ko- } \\
\text { palnych). }\end{array}$ \\
\hline \multirow{2}{*}{$\begin{array}{l}\text { Wariant } \\
\text { pożądany }\end{array}$} & $\begin{array}{l}\text { W tym wariancie rząd ogłasza do końca 2019 roku. Program bądź reformę (wybór jest ciągle } \\
\text { sprawą otwartą, wymaga krytycznej analizy). }\end{array}$ \\
\hline
\end{tabular}


Rząd nie podejmuje inicjatywy na rzecz programu/reformy.

Siły oddolne organizują się na rzecz obywatelskiego środowiska programu/reformy. Są to działa-

Wariant wymuszony nia obejmujące zarówno koncepcje programu/reformy, inicjatywy ustawodawcze, działania praktyczne (wdrożeniowe) możliwe w istniejącym środowisku prawnym. Wreszcie działania polegające na wywieraniu presji na rządzących w sprawie włączenia programu/reformy w obszar rządowej aktywności. Z natury rzeczy, w środowisku obywatelskim program/reforma mogą powstawać tylko w trybie samoistnej konsolidacji dokonującej się na bazie wiedzy i kapitału społecznego.

Jest to rynek fakultatywny energii elektrycznej charakterystyczny dla pierwszej fazy transformacji. Funkcjonuje on w obrębie infrastruktury sieciowej NN-Sn i korzysta z dostępu do niej w zakresie wynikającym z zasady TPA+, redukującej odpowiedzialność operatorów (przesyłowego osp, dystrybucyjnych OSD i OSDn) do odpowiedzialności za system technologiczny KSE, i przenoszącej na rynek (fakultatywny) „odpowiedzialność” za podaż energii elektrycznej dla jego uczestników.

To oznacza ustrojowy charakter reformy (rynku energii elektrycznej). Oznacza też, że zasada TPA+ obejmuje dostęp do zasobów energii elektrycznej (łącznie z usługami systemowymi) rynku schodzącego wek na osłonie kontrolnej OK4, czyli na osłonie rozdzielającej KSE na obecną część systemową z jednostkami wytwórczymi centralnie dysponowanymi (JWCD) i infrastrukturą sieciową 400-220-110 kV oraz na infrastrukturę sieciową nN-SN (na której funkcjonuje rynek fakultatywny). Na tym zasadza się istota ustrojowej reformy (rynku energii elektrycznej). Mianowicie, jest nią wytworzenie (za pomocą reformy) konkurencji na osłonie wirtualnej OK4 (obejmującej wszystkie GPZ-y, czyli stacje transformatorowe 110/Sn): w pierwszej fazie (do roku 2025) Między rynkiem wschodzącym 1) oraz rynkiem schodzącym WEK, a w drugiej (po roku 2025) Między rynkiem wschodzącym 2) (rynek offshore) oraz rynkiem schodzącym wek i rynkiem wschodzącym 1).

Egzekutorem dekompozycji bezpieczeństwa elektroenergetycznego - na rynku fakultatywnym

Rynek wschodzący 1) rynku (fakultatywnego) obejmująca: sieciowy terminal dostępowy (STD) oraz platformę rozliczeniową operatora OIRE (operator informacji rozliczeniowej energii elektrycznej), w skrócie platformę rozliczeniową OIRE.

Terminal STD jest infrastrukturą technologiczną (energoelektroniczno-teleinformatyczną hardwarowo-softwarowa) pretendenta do rynku wschodzącego 1), inaczej do wejścia na platformę prawną TPA+. Pretendentem (w ujęciu podmiotowym) jest odbiorca, prosument, niezależny inwestor. W ujęciu przedmiotowym istotą zasady TPA+ jest samoistne wytwarzanie się wirtualnych systemów elektroenergetycznych (WSE), w skrócie platform WSE, konsolidujących się w procesie transformacji w rynek wschodzący 1). Terminale STD podlegają (niezależnej) certyfikacji z uwagi na zgodność z kodeksami sieciowymi (nowymi) operatorów OSD (OSDn) odpowiedzialnych za bezpieczeństwo techniczne infrastruktury sieciowej nN-SN. Licznik rozliczeniowy energii elektrycznej, włączony w strukturę terminala STD (stanowiący jego podstawowe wyposażenie) podlega odrębnej niezależnej certyfikacji.

Platforma OIRE jest infrastrukturą technologiczną (informatyczną) gwarantującą konkurencję na rynku wschodzącym 1), czyli gwarantującą pretendentom rynkowy dostęp do energii elektrycznej z jednotowarowego (obejmującego opłaty sieciowe i usługi systemowe KSE) rynku schodzącego wek. Platforma zapewnia 5-minutową częstość odczytów liczników rozliczeniowych energii elektrycznej. Częstość rozliczeń energii elektrycznej jest natomiast związana z systemem opłat sieciowych (dwa podstawowe to: net metering oraz roaming elektroenergetyczny.

Obejmuje - w wariancie wymuszonym - trzy ściśle powiązane pakiety działań realizowanych w trybie oddolnym w okresie październik 2019-2020. W wariancie pożądanym wyrazistość kryzysowego charaktery trójpaku jest złagodzona przez działanie rządu.

Trójpak kryzysowy i bazy (społeczeństwa). Nadal pozostaje jednak w trójpaku duża część działań, których kryzysowego charaktery do końca nie da się już wyeliminować. Ma to na obecnym etapie główną przyczynę w deficycie kompetencyjnym, zarówno po stronie rządu jak i sił oddolnych. 
I pakiet - obejmuje opracowanie pilotażowego (małego) pakietu nowelizacji ustawowych pobudzających rozwój rynku wschodzącego 1) na jego podstawach fundamentalnych, celem ochrony sytemu prawnego przed jego degradacją za pomocą regulacji wybiórczych, podporządkowanych nowym grupom interesów. Regulacje podporządkowane fundamentalnym podstawom (respektujące osiągalny już poziom technologiczny, właściwy dla monizmu elektrycznego OZE) obejmują: rozwiązania rynku bilansującego rbı (budowanego w trybie „przybudówki” do rynku RB na rynku schodzącym wek), platformę OIRE oraz terminal STD. Szczególne znaczenie i pakietu wynika z jego siły pobudzającej rozwój całkowicie nowej struktury rynku wschodzącego 1). W tym aspekcie szczególnie ważna jest procesowa (stopniowa) unifikacja rynku bilansującego rbı z powszechną taryfą dynamiczną TD oraz z rynkiem transakcji pakietowych.

Il pakiet - obejmuje regulacje umożliwiające stworzenie w trybie poligonów wdrożeniowych rozwiązań biznesowych typu WSE (wirtualny system elektroenergetyczny) w sposób ewolucyjny przekształcających się (samoistnie) w horyzoncie $2025 \mathrm{~W}$ rynek wschodzący 1 ). W środowisku trójpaku kryzysowego zbiór rozwiązań biznesowych typu WSE musi być zbiorem otwartym. Wyjściowo zbiór ten tworzą takie zakorzenione już mocno rozwiązania jak: elektrownia wirtualna, klaster energii, spółdzielnia energetyczna. Nowym wielkim obszarem domagającym się rozwiązania są w tym kontekście spółdzielnie mieszkaniowe (wspólnoty, osiedla deweloperskie). Jednak rozwiązania szczególne nie mogą być mnożone. Przeciwnie, potrzebna jest (w horyzoncie 2025) unifikacja rozwiązań do jednolitego rynku wschodzącego 1). Temu służy koncepcja poligonów. Realizacja koncepcji ma stworzyć podstawy pod unifikację.

III pakiet - mała unifikacja prawna kończąca trójpak kryzysowy. Jest to unifikacja i pakietu do postaci zasady TPA+ $w$ trybie nowelizacji (koniec 2020) ustawy prawo energetyczne. Wynikiem tej unifikacji, bazującej na koncepcji terminala STD (i rezultatach pakietu II), jest unifikacja technologiczna prosumenckich instalacji wewnętrznych oraz operatorskich sieci NN i unifikacja zasad bezpieczeństwa elektrycznego w tym obszarze.

Jest to duża unifikacja systemu prawnego ustrojowej reformy rynku energii elektrycznej

Prawo kończąca reformę (2025), rozpoczynająca końcową fazę super unifikacji technologiczno-

elektryczne biznesowej rynku wschodzącego 1).

Prawo elektryczne przekształca regulację ex ante rynku energii elektrycznej w regulację ex post (w regulację antymonopolową). 


\section{Podstawy fundamentalne}

Zbiór sześciu załączników składających się na podstawy fundamentalne transformacji energetycznej z pozoru tyko jest zbiorem eklektycznym. Pod względem treści zbiór jest spójny w najważniejszym aspekcie: pod względem znaczenia równoważy zagadnienia teoretyczne oraz praktyczne. Ponadto jest nasycony próbami (przykładami) unifikacji licznych „zróżnicowanych” zagadnień transformacyjnych, traktowanych obecnie rozdzielnie (tylko z powodu przejściowego braku ich pogłębionego rozpoznania); są to unifikacje majace potencjał przyspieszania budowy metody monizmu elektrycznego OZE. Tym samym mają potencjał dobrej organizacji złożonego procesu realizacyjnego transformacji.

Niespójność załączników (która jednak nie powoduje ich eklektyzmu) jest na pewno związana z ich kompletnościa, a raczej ze zróżnicowanym stopniem niekompletności (bo wszystkie są niekompletne, tylko jedne mniej, a drugie bardziej). $Z$ tego punktu widzenia w wypadku załącznika 6 , niezwykle ważnego w kontekście metody monizmu elektrycznego OZE, nie można mówić o jakiejkolwiek kompletności - jest on jedynie wywołaniem problemu.

Załącznik 1. Triplet paradygmatyczny transformacji (Hasłowy opis paradygmatów. Kanoniczny zbiór sześciu technologii transformacyjnych. Transformacja energetyki: miliony innowacji twardych oraz miękkich i jedna przełomowa. Tablica praktycznych, szacunkowych, współczynników transformacji bilansów energetycznych do monizmu elektrycznego OZE).

Można się doszukiwać sprzeczności w tytule tego załącznika, gdyż cechą paradygmatów jest trwałość, zaś transformacja jest z natury zmiana. Ponadto, czy w erze cyfrowej, której istotą są szokowe zmiany w ogóle (na razie zachodzące w dominującej części poza energetyka), można szukać fundamentów, które w energetyce będą skutecznie opierać się czasowi?

Podstawy do przezwyciężania pozornych sprzeczności trzeba szukać w monizmie elektrycznym OZE, który jest celem transformacji energetyki w horyzoncie 2050 i w tym horyzoncie ją napędza (redukuje w dodatku jej liczne ryzyka). Otóż monizm elektryczny OZE 2050 zapewniający, poprzez transformację, neutralność klimatyczną (już w połowie stulecia) wydłuża horyzont stabilnego rozwoju świata (w kontekście zaspakajania 
potrzeb energetycznych) przynajmniej do końca stulecia, to znaczy do czasu ewentualnego kryzysu surowcowego (przed ryzykiem tego kryzysu monizm elektryczny OZE świata na razie nie chroni). W takim ujęciu (dwóch perspektyw i ośmiu dekad) triplet składający się z paradygmatów prosumenckiego (eklektycznego), egzergetycznego (twardego), wirtualizacyjnego (znowu eklektycznego) spełnia kryterium długowieczności (długotrwałości) wymagane w wypadku każdego paradygmatu. Przez trzy dekady będzie kompatybilizował transformację, a przez co najmniej pięć dekad podtrzymywał monizm.

Dodatkowo, uwolnienie od drugiej pozornej sprzeczności niesie z sobą krytyczna analiza pytania, co jest ważniejsze: czy to, że transformacja energetyki realizuje się za pomocą milionów współzależnych - i w dominującym stopniu zespołowych (nasyconych twórczą współpraca) - innowacji (twardych i miękkich), czy to, że jest to jedna (jedyna) innowacja przełomowa. Odpowiedź w tym wypadku może być tylko jedna: bez milionów innowacji jedna przełomowa nie byłaby możliwa.

Triplet wręcz przesądza jedność milionów innowacji trwającej ery cyfrowej (paradygmat wirtualizacyjny) $i$ rozpoczynającej się ery prosumeryzmu, nie tylko energetycznego (paradygmat prosumencki) oraz jednej innowacji przełomowej, o której klasyczna (ogólna) definicja mówi, że polega na zmianie sposobu funkcjonowania wielkiego (pod względem wartości), powszechnego (w kontekście potrzeb i zasięgu) rynku, w dodatku $\mathrm{z}$ bardzo silnymi podmiotami zasiedziałymi (w postaci grup interesów ukształtowanych w długim historycznym procesie). A właśnie na tym polega transformacja energetyki do monizmu elektrycznego OZE, który podstawę ma w paradygmacie egzergetycznym: jest „ugruntowany” na najbardziej podstawowych, czyli najbardziej trwałych równaniach (makroskopowej) termodynamiki i elektromagnetyzmu.

\section{Hasłowy (w tym za pomocq synonimów) opis paradygmatów}

Paradygmat prosumencki jest paradygmatem efektu prosumenckiego łańcucha wartości, wzmacnianego przez efekt fabryczny (skalowalności), zastępującego efekt skali WEK. Paradygmat egzergetyczny jest paradygmatem zwalczania wielkich strat egzergii chemicznej i jądrowej za pomocą wysokoegzergetycznej energii elektrycznej ze źródeł OZE (i wykorzystania egzergii surowców nieenergetycznych w pasywizacji budownictwa oraz strat egzergii źródła dolnego pompy ciepła napędzanej energią elektryczna). 
Paradygmat wirtualizacyjny jest paradygmatem współużytkowania sieci elektroenergetycznych (paradygmat zasady TPA+ pozwalającej na intensyfikację wykorzystania sieci za pomocą konkurencji na rynku energii elektrycznej w przestrzeni ograniczeń sieciowych zarządzanych przez inteligentne sieciowe terminale dostępowe STD).

Proponowana lista synonimów dla paradygmatu prosumenckiego, to paradygmat: anty-korporacyjny, pro-efektywnościowy, pro-edukacyjny, behawiorystyczny itd.

Proponowana lista synonimów dla paradygmatu egzergetycznego, to paradygmat: anty-entropijny (opóźnianie wzrostu entropii w czasie), proefektywnościowy, transformacji energetyki termodynamicznej w elektrotechniczną itd.

Proponowana lista synonimów dla paradygmatu wirtualizacyjnego, to paradygmat: anty-monopolowy, wykorzystania sieci nN-SN, zasady TPA+, mikrotransakcji, prymatu mikroekonomii nad makroekonomia, wynikania makroekonomii z mikroekonomii itd.

\section{Kanoniczny zbiór sześciu technologii transformacyjnych}

Triplet paradygmatyczny (możliwość jego sformułowania) implikujący prostotę i elegancję metody badawczej, właściwej dla monizmu elektrycznego OZE, jest potwierdzeniem, że ukształtowanie się (łącznie z pełną komercjalizacja) w ciagu zaledwie trzech dekad kanonicznego już zbioru sześciu technologii transformacyjnych nie jest przypadkiem (te technologie, to: $1^{\circ}$ - źródła wytwórcze (energii elektrycznej) OZE, $2^{\circ}$ - technologie domu pasywnego, $3^{\circ}$ - pompa ciepła, $4^{\circ}$ - samochód elektryczny, $5^{\circ}$ - technologie zasobnikowe (akumulatory elektryczne, ale nie tylko) i $6^{\circ}$ - caly, bardzo eklektyczny, zbiór technologii kryjących się pod nazwa „,inteligentna infrastruktura”).

W wypadku technologii wytwórczych OZE trzeba wyraźnie rozróżnić dwa rodzaje źródeł: z produkcją wymuszona (wiatrowe i PV) oraz źródła biogazowe, łatwe w dostosowaniu do pracy regulacyjno-bilansującej. Każde z ich można łatwo scharakteryzować za pomocą trzech bardzo stabilnych rynkowo wielkości, którymi sa: moc jednostkowa P, roczny czas wykorzystania mocy znamionowej T oraz cena jednostkowa $\mathrm{C}$ (jest to bardzo ważna właściwość z punktu widzenia rozwoju globalnej konkurencji na rynkach produkcji źródeł i na samych rynkach energii elektrycznej, jej brak w wypadku źródeł charakterystycznych dla energetyki WEK był zawsze w wypadku tej energetyki silna barierą wzrostu konkurencji). 
Źródła wytwórcze OZE z produkcją wymuszoną, uszeregowane zgodnie z chronologicznym rozwojem do końca roku 2018, zostały zestawione (w kontekście wielkości P, T, C) w tabeli 4.

Komentarz w odniesieniu do mocy P jest następujący: górna granica jednostkowych mocy elektrowni wiatrowych lądowych $\mathrm{z}$ dużym prawdopodobieństwem w bliskim czasie nie zostanie przekroczona. Zupełnie inaczej jest w wypadku elektrowni wiatrowych morskich - w tym wypadku zapowiadany jest przez producentów wzrost mocy do 12 MW już roku 2022.

Tabela 4. Źródła OZE z produkcją wymuszoną

\begin{tabular}{llll}
\hline Źródło & $P$ & $T$ [godz.] & $C$ \\
\hline Elektrownie wiatrowe lądowe & $2-3,5 \mathrm{MW}$ & 3500 & $1,3 \mathrm{mln} € / \mathrm{MW}$ \\
\hline Źródła dachowe PV & $2-10 \mathrm{~kW}$ & 1000 & $1000 € / \mathrm{kW}$ \\
\hline Elektrownie wiatrowe morskie, offshore & $5-7 \mathrm{MW}$ & 4500 & $1,7 \mathrm{mln} € / \mathrm{MW}$ \\
\hline
\end{tabular}

Odrębną sprawa jest koncentracja mocy w farmach wiatrowych (lądowych i morskich) oraz w farmach PV. W wypadku lądowych elektrowni wiatrowych największe farmy osiagają w Polsce moc 100 MW i więcej. Z drugiej strony decentralizacja wytwarzania będzie eliminowała wiatrowe farmy lądowe $z$ (antycypowanego) konkurencyjnego rynku wschodzącego energii elektrycznej - funkcjonującego na infrastrukturze sieciowej SN - pozostawiając miejsce tylko dla pojedynczych elektrowni budowanych w rozproszeniu (w sposób umożliwiający ich przyłączenie do sieci SN).

Przeciwny trend rynkowy występuje w wypadku farm morskich, gdzie koncentracja mocy gwałtownie rośnie. Uruchamiana (2019) największa farma na Morzu Północnym ma już moc 1,2 GW (energetycznie jest porównywalna z największymi blokami węglowymi, czyli klasy 1000 MW, i „staje” się porównywalna z blokami jądrowymi).

W odniesieniu do źródeł PV podkreśla się, że podany w tabeli 4 zakres ich mocy jest charakterystyczny dla domów jednorodzinnych. Dla budynków wielorodzinnych zakres ten można rozszerzyć do $50 \mathrm{~kW}$. Na dachach hal fabrycznych można instalować źródła nawet o mocy 1 MW (zapotrzebowana powierzchnia dachu, w części nadającej się do wykorzystania, wynosi - uwzględniając korytarze serwisowe - około 1 ha). 
Dachowe źródła PV - zintegrowane z budynkiem w ramach syntezy architektonicznoenergetycznej, pokrywające lokalne/budynkowe zapotrzebowanie na energię elektryczna - pozostaną podstawowym segmentem źródeł PV. Nie ma natomiast przesłanek (przede wszystkim zaś potrzeb) do budowy farm (źródeł pracujących „na” sieć) o mocy większej niż 1 MW (o zapotrzebowanej powierzchni gruntu wynoszącej ponad $1 \mathrm{ha}$ ).

Tabela 5. Źródła biogazowe, nadające się do łatwego przystosowania do pracy regulacyjno-bilansującej

\begin{tabular}{llll}
\hline Źródło & $P$ & T [godz.] & C [szt.] \\
\hline Mikroelektrownie biogazowe & $10-50 \mathrm{~kW}$ & 8000 & $250-750$ tys. PLN \\
\hline Elektrownie biogazowe & $0,5-1 \mathrm{MW}$ & 8000 & $8-12 \mathrm{mln}$ PLN \\
\hline
\end{tabular}

Źródła biogazowe zostały przedstawione w tabeli 5. Dane tam przedstawione odnosza się do źródeł pracujących w trybie wymuszonym. Trzeba pamiętać, że proces zgazowania biologicznego w komorze fermentacyjnej źródła biogazowego jest procesem bardzo stabilnym - możliwości jego modyfikacji, przyśpieszania/opóźniania - są ograniczone. Dlatego pod tym względem (abstrahując od faktu, że moc jest trzy rzędy niższa) źródło jest podobne do bloku jądrowego. Mianowicie roczny czas wykorzystania jego mocy zainstalowanej/znamionowej wynosi około 8000 godzin).

Z drugiej jednak strony jest łatwość wytworzenia w komorze fermentacyjnej zdolności magazynowej, a także wyposażenia źródła w zintegrowany (chociaż zewnętrzny w stosunku do komory) magazyn biogazu. W rezultacie o znaczeniu źródeł biogazowych decydują ich zdolności regulacyjno-bilansujące na rynku energii elektrycznej, ich rola w gospodarce o obiegu zamkniętym (funkcje utylizacyjne w gospodarce odpadami komunalnymi), wreszcie rola w restrukturyzacji rolnictwa (w UE chodzi o wykorzystanie tych źródeł do budowy drugiej „nogi” rozwojowej obszarów wiejskich, będącej odpowiedzią na redukcję Wspólnej Polityki Rolnej i potrzebę aktywnego zarządzania ryzykiem produkcji rolnej, zarówno roślinnej jak i hodowlanej).

Inną sprawą w wypadku źródeł biogazowych jest standard określania ich cen. Bardziej właściwe jest posługiwanie się w wypadku tych źródeł nie nakładami inwestycyjnymi jednostkowymi, a całych instalacji: od magazynu substratów aż do stacji transformatorowej zapewniającej połączenie źródła z siecią elektroenergetyczną i z uwzględnieniem stacji wymiennikowej zapewniającej połączenie źródła z odbiorami ciepła (poza potrzebami 
własnymi źródła), a także z uwzględnieniem instalacji utylizacji osadów pofermentacyjnych. W takim standardzie zostały zapisane ceny źródeł biogazowych w tabeli 5.

Bardzo krótka charakterystyka pozostałych pięciu technologii ze zbioru umownego (poza technologiami wytwórczymi OZE), jest następująca. Technologie pasywne to te, które umożliwiają budowę nowych budynków mieszkalnych (rocznie około 70 tys. domów jednorodzinnych i około 80 tys. mieszkań w budownictwie wielorodzinnym) o bardzo małym zapotrzebowaniu na ciepło grzewcze, ale także rewitalizację (przy pewnych ograniczeniach) istniejących zasobów mieszkaniowych (6 mln domów jednorodzinnych i 6 mln mieszkań w 450 tys. budynków wielorodzinnych). Technologie pasywne pozwalająca statystycznie zmniejszyć zapotrzebowanie na ciepło grzewcze nawet 5-krotnie w stosunku do stanu istniejącego.

Monowalentna pompa ciepła, służąca do ogrzewania i klimatyzacji zasobów mieszkaniowych (również innych zasobów budynkowych), czyli do zapewnienia komfortu cieplnego oraz do produkcji ciepłej wody użytkowej - to technologia pozwalająca przetworzyć elektryczną energię napędową w ponad 3-krotnie większą ilość ciepła użytkowego.

Samochód elektryczny (zarówno mały miejski, na krótkie trasy, jak również dostępny już duży, przeznaczony do użytkowania na autostradach, o zasięgu na jednym ładowaniu wynoszącym kilkaset kilometrów), to technologia, która pozwala zaspakajać potrzeby transportowe ze sprawnością 3-krotnie wyższą niż sprawność energetyczna samochodu tradycyjnego, wyposażonego w silnik spalinowy. Oczywiście, technologia pod nazwa „samochód elektryczny” obejmuje także miejski autobus elektryczny i pojazdy specjalistyczne. Wreszcie, wraz z rozwojem technologii akumulatorowych, także autobus do użytkowania na autostradach oraz samochód ciężarowy (do użytkowania w transporcie lokalnym i dalekosiężnym).

W kontekście transformacji energetyki do monizmu elektrycznego OZE kluczowe są technologie akumulatorowe. Weszły już w etap przełomowy rozwoju (taki, jaki maja już za sobą technologie wiatrowe lądowe, fotowoltaiczne i wiatrowe morskie); czas do wysycenia rozwojowego technologii antycypuje się na około 10 lat. Dwa segmenty, które napędzają rozwój technologii akumulatorowych, to monizm elektryczny OZE na rynku wytwórczym energii elektrycznej oraz transport elektryczny. 


\section{Transformacja energetpki do monizmu elektrycznego OZE: miliony innowacji,} twardych i miękkich, czy jedna przełomowa)

Przedstawiony podział technologii jest zasadny w świetle teorii i praktyki transformacji energetyki. Każda $z$ tych technologii ma silne powiązanie $z$ fundamentalnymi prawami termodynamiki i/lub elektromagnetyzmu (od elektrotechniki po optoelektronikę).

Jednak prawa te same nie rozstrzygają o przedstawionym uporządkowaniu technologii. Do rozstrzygnięcia potrzebny był jeszcze postęp w inżynierii materiałowej w tak różnych obszarach, jak budownictwo na jednym krańcu oraz elektronika i energoelektronika na drugim. I to właśnie inżynieria materiałowa sprawiła, że fundamentalne prawa doczekały się technologii konkurencyjnych na rynku. Trzeba przy tym pamiętać, że rynkowa konkurencyjność technologii rozstrzyga się w świecie decyzji mikroekonomicznych, czyli podejmowanych masowo i w sposób ciagły. Rozwój technologii, konieczny do zdobycia przez nie konkurencyjności jest w ostatnich latach udziałem milionów innowatorów, czyli odbywa się również masowo i w sposób ciagły.

Tak dopełniły się wszystkie warunki potrzebne do tego, aby przełom w energetyce stał się faktem i aby uznać go za fundamentalny. Dlatego, że jest on w świecie nauki synteza metody dedukcyjnej (fundamentalne prawa termodynamiki i elektrotechniki) oraz indukcyjnej (masowy/rynkowy rozwój technologiczny powstający w laboratoriach badawczych i w fabrykach oraz jego masowa/rynkowa dyfuzja w obszar zastosowań). Mówiąc inaczej - jest synteza praw odkrytych przez genialnych wynalazców (prawom tym nie może się w żaden sposób wymknąć), rozwoju technologicznego oferowanego przez miliony innowatorów, i wreszcie - na poziomie hipotezy - potencjalnej powszechnej gotowości (zdolności) prosumentów do wchłonięcia nowych technologii.

W kontekście hipotezy dotyczącej potencjału dyfuzji rynkowej nowych technologii podkreśla się, że rzeczywista faza przełomu (jego dynamika) jest na świecie bardzo zróżnicowana. Trzy czynniki (umownie) decydują o dynamice przełomu: stan prawno-regulacyjny (polityka), postęp technologiczny (ekonomia, konkurencyjność nowych technologii), kompetencje (zarówno elitarne-zawodowe, jak i powszechne).

Z punktu widzenia tych trzech czynników podstawowe znaczenie ma przeciwstawienie skrajnie „przyjaznego” (prostego), przynajmniej na początek, opisu nowych technologii ze zbioru umownego niezwykle hermetycznemu (bardzo skomplikowanemu) opisowi energetyki WEK (paliw kopalnych). 
Porównanie tych dwóch opisów daje pierwszą odpowiedź odnośnie perspektyw monizmu elektrycznego OZE. Szczególnie ważne są w tym aspekcie dwie hipotezy robocze dotyczące: $1^{\circ}$ - dużej odporności monizmu elektrycznego OZE na budowanie grup interesów charakterystycznych dla energetyki WEK, $2^{\circ}$ - bardzo dużego potencjału rynkowej dyfuzji nowych technologii.

Trzeba przy tym pamiętać, że rynkowa konkurencyjność technologii rozstrzyga się w świecie decyzji mikroekonomicznych, czyli podejmowanych masowo i w sposób ciągły. W szczególności rozwój technologii, konieczny do zdobycia przez nie konkurencyjności rynkowej jest w ostatnich latach udziałem milionów innowatorów, czyli odbywa się również masowo i w sposób ciagły. Dalej rozwój technologiczny oferowany jest również przez miliony innowatorów. Wreszcie potencjał rynkowej dyfuzji nowych technologii jest wynikiem powszechnej gotowości (zdolności) prosumentów do wchłonięcia tych technologii.

\section{Tablica praktycznych (szacunkowych) współczynników transformacji bilansów energetycznych do monizmu elektrycznego OZE}

Z tripletu paradygmatycznego transformacji energetycznej wynikaja wprost ramy ustalania praktycznych rozwiązań na rynku energii elektrycznej stanowiącym główną siłę sprawczą kształtująca trajektorię transformacji energetycznej od stanu A do stanu B. W tym kontekście podkreśla się, że (ewolucyjna) transformacja energetyczna nie jest mechanicznym odtwarzaniem programu zawartego w warunkach początkowych (stan A). Stanowi natomiast proces twórczy, w którym jest miejsce na kreację, jednak za pomocą mechanizmów rynkowych (decyzji mikroekonomicznych), a nie za pomoca polityki energetycznej narzucanej z poziomu makroekonomicznego (władztwa nadbudowy, która utraciła jednak kompetencje).

Dlatego stanów A i B w transformacji energetyki nie da się bezpośrednio traktować w kategoriach równania stanu termodynamicznego, które jest opisem tego stanu wykorzystującym trzy parametry termiczne: ciśnienie, temperaturę i objętość właściwą (oczywiście, tylko dwa z nich są niezależne); przy tym kardynalną właściwością równania stanu jest to, że nie jest ono wrażliwe na trajektorie przejścia układu z jednego stanu $\mathrm{w}$ drugi. Z drugiej strony, pożyteczne jest szukanie inspiracji w działaniu równania stanu do potrzeb kształtowania trajektorii transformacyjnej energetyki między stanami A i B. 
Stan B (horyzont 2050, pełna reelektryfikacja OZE, monizm elektryczny) jest w obecnej rzeczywistości technologicznej, ekonomicznej i społecznej dostatecznie odległy, aby stwierdzić, że niezależnie od trajektorii zostanie on osiagnięty. Tablica praktycznych współczynników transformacji energetycznej do monizmu elektrycznego w pierwszym podejściu (wymagającym surowej weryfikacji) jest bardzo prosta - tabela 6. Centralna kategorią monizmu elektrycznego jest energia użyteczna $E_{u \dot{z}}$ w postaci energii elektrycznej ze źródeł OZE potrzebna do zaspokojenia wszystkich prosumenckich potrzeb energetycznych.

Tabela 6. Tablica praktycznych (szacunkowych) współczynników transformacji energetycznej do monizmu elektrycznego

\begin{tabular}{|c|c|c|c|c|c|}
\hline \multicolumn{2}{|c|}{ Rynek energetyczny } & „Czynnik” napędowy & Jednostka „wiążąca” & Wzór & $\begin{array}{c}\text { Oszacowanie } \\
\text { liczbowe }\end{array}$ \\
\hline \multicolumn{2}{|c|}{ Energia elektryczna } & Ludność, gospodarka & kWh/(os., PKB) & $(-)$ & 1 \\
\hline \multirow{2}{*}{ Ciepło } & $\begin{array}{l}\text { grzewcze, } \\
\text { CG }\end{array}$ & $\begin{array}{l}\text { Ludność, } \\
\text { mieszkalnictwo }\end{array}$ & $\mathrm{kWh} / \mathrm{m}^{2}$ & $\frac{E_{P H}}{E_{g}} \cdot \frac{1}{C O P}$ & $\frac{1}{3} \cdot \frac{1}{3}=0,1$ \\
\hline & CWU & Ludność & kWh/os. & $\frac{1}{C O P}$ & $\frac{1}{3}=0,3$ \\
\hline \multicolumn{2}{|c|}{ Transport } & Ludność, transport & kWh/sam. & $\frac{\eta_{s}}{\eta_{E V}}$ & $\frac{0,2}{0,6}=0,3$ \\
\hline
\end{tabular}




\section{Załącznik 2. Reforma ustrojowa rynku energii elektrycznej (unifikacja słaba, silna i super unifikacja rynku wschodzącego 1) energii elektrycznej)}

Kryzys ogólnie ujawniający się z coraz większą siłą w elektroenergetyce, wielkie zapóźnienie w zakresie dostosowywania systemów taryfowych krajowego rynku końcowego energii elektrycznej do współczesnych wymagań (i możliwości technologicznych), wielkie zapóźnienie w stosunku do procesów liberalizacji rynku energii elektrycznej wywołanych Pakietem Zimonym w UE, a jednocześnie fundamentalne znaczenie rynku energii elektrycznej w całej transformacji energetyki do monizmu elektrycznego OZE 2050, powoduje konieczność natychmiastowych (2020) działań.

Wyjściowa (2019) architektura rynku transformacyjnego energii elektrycznej, wiarygodnie uprawdopodobniona już na poziomie hipotez badawczych (zapewniająca wystarczająca siłę głównych interakcji rynkowych) obejmuje jego trzy segmenty (rynki): „rynek” schodzący WEK (rozpostarty na systemie KSE w jego obecnej postaci), rynek wschodzący 1) (wykorzystujący „własne” zasoby wytwórcze OZE z wyjątkiem offshoromych, korzystający z dostępu do infrastruktury sieciowej nN-SN i zasobów KSE zgodnie z zasada TPA+, por. załącznik 4) oraz rynek wschodzący 2) (wykorzystujący zasoby wytwórcze offshore, korzystający z rynkowego dostępu do infrastruktury sieciowej 400220-110 kV i innych zasobów KSE).

\section{Trzy historyczne etapy konkurencji w elektroenergetyce}

Rozwój konkurencji w elektroenergetyce zawsze wiązał się z przebudowa grup interesów. Początki konkurencji w elektroenergetyce należy łączyć z ustawą Public Utility Regulatory Policies Act - PURPA, uchwaloną przez Kongres USA w roku 1978 (weszła w życie dopiero w roku 1982), która wykreowała (poza energetyką WEK) segment niezależnych inwestorów, czyli wytwórców w obszarze wielkoskalowej kogeneracji węglowej (amerykańscy wytwórcy IPP - Independent Power Producers). Podstawą rozwoju pierwszego segmentu niezależnych inwestorów były inwestycje realizowane w oparciu o bardzo silną zasadę kosztów unikniętych (stanowiących istotę ustawy PURPA) na rynku energii elektrycznej i otwartą konkurencję na rynku ciepła. 
Zasada TPA wykreowała kolejny (drugi) etap konkurencji, czyli przedsiębiorców handlujących na własne ryzyko energią elektryczną na rynku WEK, w środowisku stworzonym przez tę zasadę (amerykańscy marketersi wykorzystali zasadę TPA do przebudowy hurtowego rynku USA, korzystając z dużych różnic cen energii elektrycznej na wschodzie i na zachodzie kraju, uznawanej za „naturalna”, kiedy „panował” monopol).

Niemiecki program strategicznej przebudowy elektroenergetyki znany powszechnie pod nazwą Energiewende (zapoczątkowany ustawą EEG o źródłach odnawialnych z roku 2000, od roku 2014 obowiązującą w znowelizowanej postaci EEG 2.0) i unijna dyrektywa 2009/28 przyspieszyły gwałtownie rozwój energetyki OZE i nadały procesowi demonopolizacji elektroenergetyki nowy wymiar. Wykreowany został strategiczny sektor niezależnych inwestorów w obszarze energetyki wiatrowej, który zapoczątkował trzeci etap konkurencji, między energetyką OZE i energetyką paliw kopalnych.

\section{Rozpoczynający się, najbardziej radykalny, czwarty etap konkurencji $w$ elektroenergetyce}

Pierwsze trzy etapy konkurencji w elektroenergetyce nie naruszyły blokującej pozycji sieci elektroenergetycznych na rynku energii elektrycznej. Dopiero rozwój źródeł PV oraz pojawienie się na masową skalę prosumentów (segment ludnościowy) zmienia tę sytuację i prowadzi do obecnego, czwartego, najbardziej radykalnego etapu konkurencji.

Radykalizm tego etapu wynika, po pierwsze, z drastycznej rozbieżności między znikomym obecnym wykorzystaniem sieci SN-nN pracujących w układach otwartych jednostronnie zasilanych oraz osiagalnymi już technologiami (terminale STD) zarządzania procesem intensyfikacji wykorzystania zdolności przyłączeniowych i dystrybucyjnych sieci $\mathrm{SN}$-nN pracujących, z uwagi na masowo przyłączane rozproszone źródła OZE, w układach hiperzamkniętych.

Po drugie, radykalizm ten jest napędzany drastyczną rozbieżnością między archaicznym taryfowym rynkiem końcowym energii elektrycznej oraz dostępnymi technologiami pomiarowo-rozliczeniowymi (właściwość platformy OIRE).

Po trzecie, ma on przyczynę (i to jest sprawa najważniejsza) w obowiązującym systemie opłat sieciowych, które nie maja związku z podstawami elektrotechniki, wynikaja natomiast $z$ systemu regulacji prawnych chroniacych interesy elektroenergetyki WEK, ale blokujących działanie fundamentalnych mechanizmów konkurencji rynkowej i innowacje technologiczne. 
Są to trzy rozbieżności (przyczyny) o krytycznym znaczeniu na drodze do zdecentralizowanego rynku RCR (rynek czasu rzeczywistego). Szansą na ich złagodzenie w Europie jest ustrój prawny ram (2030) polityki klimatyczno-energetycznej, tabela 1 . W jego strukturze można szukać przesłanek do projektowania rozwiązań dla ustrojowej reformy rynku energii elektrycznej w Polsce. Taka struktura Pakietu tworzy wyraziście „modelowe” środowisko regulacyjne transformacji energetyki do prosumenckiego monizmu elektrycznego OZE. Mianowicie jest to (w tendencji) środowisko ze zminimalizowanymi zasobami sieciowymi i zmaksymalizowanymi prosumenckimi zdolnościami regulacyjno-bilansującymi (środowisko nazywane „obywatelską społecznością energetyczną").

Polskie uwarunkowania (kryzys w elektroenergetyce) stawiaja przed ustrojową reformą rynku energii elektrycznej większe wymagania. Wymagają w szczególności stosowania w szerokim zakresu rozwiązań pilotażowych już w roku 2020 i zapewnienie tym sposobem dynamiki rozwojowej rynku wschodzącego 1), umożliwiającej osiagnięcie takiej jego dojrzałości w 2025, aby umożliwiła jego dalsze funkcjonowanie bez wsparcia (wyłącznie poprzez korzystanie z własnych - rynku - sił wewnętrznych), czyli pozwalającej na likwidację dotacji. Źródła OZE (szczególnie PV i wiatrowe lądowe, ale także mikrobiogazowe i biogazowe w środowisku gospodarki obiegu zamkniętego) osiagnęły poziom technologiczny, który nie wymaga już (a w każdym razie agresywnego) ich wspierania kapitałowego (pod warunkiem dopuszczenia konkurencji między sieciami i źródłami).

W rezultacie interwencja na rzecz ustrojowej reformy rynku energii elektrycznej w Polsce powinna być w perspektywie budżetowej 2021-2027 kierowana do energetyki prosumenckiej (obejmującej cały segment ludnościowy, sektor MMSP oraz samorządy), z natury rzeczy zorientowanej na innowacje przełomowe i posiadającej większy (w stosunku do energetyki korporacyjnej) potencjał dyfuzji tych innowacji. W szczególności wsparcie powinno być ukierunkowane na rozszerzenie - za pomoca sieciowych terminali STD - obecnej zasady dostępu odbiorców energii elektrycznej do sieci (zasada TPA) na nowocześniejszą zasadę TPA+ dostępu prosumentów i inwestorów (inwestujacych w wirtualne elektrownie ze źródłami rozproszonymi OZE i w inteligentną infrastrukturę hardwarowo-softwarową zróżnicowanych platform handlowych funkcjonujacych na infrastrukturze sieciowej SN-nN KSE, będącej własnością operatorów dystrybucyjnych). 
W niewielkim natomiast stopniu wsparcie powinno być kierowane do segmentu operatorskiego (przesyłowego, dystrybucyjnego) energetyki korporacyjnej lub nawet w ogóle nie powinno być kierowane do tego segmentu. Wynika to z faktu, że wsparcie segmentu operatorskiego zablokuje rozwój ustrojowej (fundamentalnej) konkurencji między siecia i rozproszonymi źródłami OZE oraz nowymi sposobami użytkowania energii elektrycznej. A właśnie ta konkurencja jest bardzo ważnym czynnikiem dokonującej się globalnej transformacji energetycznej. I ta konkurencja spowoduje pobudzenie - w modelu prosumenckim - działań na rzecz zwiększenia efektywności wykorzystania energii elektrycznej, ale także efektywności energetycznej w transporcie i budownictwie. Zatem systemy wsparcia wzmacniające właśnie tę konkurencję pozwolą osiagnąć cel w zakresie zmniejszenia zapotrzebowania na napędową energię elektryczną w moniźmie elektrycznym OZE. Jest to znacznie trudniejsze zadanie, i znacznie pilniejsze obecnie, niż rozbudowywanie sieci $\mathrm{SN}-\mathrm{nN}$ i zwiększanie podaży energii elektrycznej z poza-prosumenckich źródeł OZE.

\section{Pierwsza konsolidacja rynku wschodzącego 1)}

Najogólniej rynek wschodzący 1), to rynek konkurujący z segmentami taryfowymi G i C oraz B rynku schodzącego WEK. Są to segmenty kojarzone jeszcze powszechnie, aczkolwiek błędnie, z odbiorcami na rynku schodzącym WEK, przyłączonymi odpowiednio do: sieci nN (taryfy G, C) oraz SN (taryfa B). Ta ostatnia sprawa jest jednym z bardzo wielu ważnych aspektów funkcjonowania elektroenergetyki, który w ciagu dziesięcioleci był poza jakąkolwiek krytyczną refleksją, co wynika np. z tabeli 7.

Tabela 7 pokazuje, że większość odbiorców elektroenergetyki WEK (w szczególności gospodarstwa domowe w budynkach wielorodzinnych), to odbiorcy „wirtualni”. W takim sensie, że nie są oni bezpośrednio przyłączeni do sieci elektroenergetyki WEK.

Z danych przedstawionych w tabeli 7 wynika dodatkowo fakt wskazujący na to, że ujednolicająca siła praktyk korporacyjnych góruje nad przesłankami fundamentalnymi. Mianowicie, udział „wirtualnych” odbiorców w Innogy wynosi 0,94, a w PGE 0,44 (przeciętnie w kraju jest to 0,61 ). Mimo wielkiej różnicy udziałów praktyka tworzenia taryf (nadzorowana bardzo „skrupulatnie” przez Urząd Regulacji Energetyki) w Innogy nie różni się istotnie od praktyki w PGE. 
Tabela 7. Rynek schodzący (WEK) energii elektrycznej, rok 2019 (segment popytowy - odbiorcy przyłączeni do sieci nN-SN, większość „wirtualnych”)

\begin{tabular}{|c|c|c|c|c|c|}
\hline \multirow{2}{*}{ OSD } & \multicolumn{2}{|c|}{$\begin{array}{l}\text { Liczba (w mln) } \\
\text { odbiorców „umownych" }\end{array}$} & \multirow{2}{*}{$\begin{array}{l}\text { Liczba }(w \mathrm{mln}) \\
\text { rzeczywistych przyłączy }\end{array}$} & \multicolumn{2}{|c|}{ Stosunek } \\
\hline & łączna & w tym „wirtualnych" & & $2: 4$ & $3: 2$ \\
\hline 1 & 2 & 3 & 4 & 5 & 6 \\
\hline PGE & 5,4 & 2,40 & 3,00 & 1,8 & 0,44 \\
\hline Tauron & 5,6 & 3,60 & 2,00 & 2,8 & 0,64 \\
\hline Energa & 3,0 & 2,00 & 1,00 & 3,0 & 0,67 \\
\hline Enea & 2,6 & 1,76 & 0,84 & 3,1 & 0,68 \\
\hline Innogy & 1,0 & 0,94 & 0,06 & 16,6 & 0,94 \\
\hline Razem & 17,6 & 10,7 & 6,90 & 2,6 & 0,61 \\
\hline
\end{tabular}

Ta konstatacja, dotycząca prymatu praktyk (interesów) korporacyjnych nad potrzebą wyzwalania pożądanej społecznie rynkowej alokacji zasobów, jest znamienna. $\mathrm{Na}$ pewno otwiera ona bezpośrednią drogę do wirtualizacji rynku wschodzącego energii elektrycznej 1). Bo nie ma powodów, aby wirtualizację (ukrytą, naganną, realizowaną w trybie transferów finansowych) mogła stosować elektroenergetyka WEK, ale nie można jej było stosować w trybie innowacji przełomowej mającej podstawę w inteligentnej infrastrukturze rynku konkurencyjnego, czyli rynku wschodzącego 1).

Aspekt wydobyty w tabeli 7 ma oprócz strony prawnej (wykorzystywanie przez elektroenergetykę WEK bezpłatnie majątku spółdzielni i wspólnot mieszkaniowych w postaci instalacji wewnętrznych $\mathrm{nN}$ między przyłączem sieciowym operatora OSD i licznikami odbiorców w postaci gospodarstw domowych) - także, a nawet przede wszystkim, podłoże mentalne. Chodzi o sposób funkcjonowania rynków powszechnych, bardzo wielkich wartościowo i krytycznych dla funkcjonowania całej gospodarki, bardzo wrażliwych politycznie, od „,zawsze” opanowanych przez bardzo silne podmioty zasiedziałe na tych rynkach, od ,zawsze” wytwarzające własne zasady obowiązujące na tych rynkach.

I to właśnie konieczność rozległych zmian mentalnych powoduje, że rynek wschodzący energii elektrycznej 1) musi być tworzony w trybie innowacji przełomowej. Pierwszą próbę ustrukturyzowania tej innowacji przedstawiają tabele 8, 9 i 10. 
Szkielet unifikacji rynku wschodzącego energii elektrycznej 1 według tab. 8, 9 i 10 jest propozycją wywoławczą, mająca na celu nie tylko pobudzenie dyskusji dotyczącej kształtowania tego rynku, ale także przejście do działań, których absolutnie nie wolno już odkładać. Składaja się na nie przede wszystkim działania realizowane w trybie programów pilotażowych pobudzających wykorzystanie zasobów uśpionych u odbiorców (przyspieszające przekształcanie się odbiorców w prosumentów i przyspieszające budowę kapitału społecznego) oraz pobudzające budowanie operatorskich (operator OSP, operatorzy OSD, operatorzy OSDn), a także prosumenckich i ogólnie biznesowych kompetencji charakterystycznych dla rynku wschodzącego energii elektrycznej 1, dalej zamiennie nazywanego też rynkiem RCR (rynek czasu rzeczywistego).

Tabela 8. Mapa analizy potencjału wykorzystania zasady TPA+ (obejmującej: sieci nN-SN oraz schodzący rynek hurtowy) do unifikacji końcowego rynku wschodzącego 1 energii elektrycznej (nowy model wirtualizacji napędzany przełomowymi innowacjami)

\begin{tabular}{|c|c|c|c|}
\hline & \multicolumn{3}{|c|}{ Podmiotowo-przedmiotowa mapa zasady TPA+ } \\
\hline & Prosument, podmiot & \multicolumn{2}{|c|}{$\begin{array}{l}\text { WSE (wirtualny system elektroenergetyczny), } \\
\text { platforma regulacyjna }\end{array}$} \\
\hline & jednowęzłowy wielowęzłowy & $\begin{array}{l}\text { WhSE (mikro), } \\
\text { wykorzystujący sieci } n N\end{array}$ & $\begin{array}{l}\text { WmSE (mini), } \\
\text { wykorzystujący sieci } \\
\text { nN-SN }\end{array}$ \\
\hline Prosument, WSW & & & \\
\hline \multicolumn{4}{|l|}{ Osłona OK } \\
\hline $\begin{array}{l}\text { Opłata sieciowa } \\
N M, R E\end{array}$ & \multirow[t]{3}{*}{$\begin{array}{l}\text { patrz } \\
\text { odrębna tabela } 8\end{array}$} & \multirow[t]{3}{*}{$\begin{array}{l}\text { patrz } \\
\text { odrębna tabela } 9\end{array}$} & \\
\hline Terminal STD & & & \\
\hline Platforma OIRE & & & \\
\hline
\end{tabular}

O ile pierwsza nazwa nawiązuje do ogólnej segmentacji rynku energii elektrycznej w procesie transformacji (całej) energetyki do monizmu elektrycznego OZE, to druga jest ukierunkowana na przełomową zmianę rynku końcowego energii elektrycznej. Jest to zmiana od systemu taryfowego (cen uśrednionych w bardzo wielu wymiarach) do rynku jednotowarowego, unifikującego (po raz pierwszy w historii elektroenergetyki) krótko- i długo-terminowe (inwestycyjne) koszty krańcowe. 
Fundamentem pod tę zmianę jest unifikacja struktury kosztów wytwarzania energii elektrycznej w źródłach OZE oraz kosztów sieciowych. W strukturze jednych i drugich kosztów dominujące są koszty stałe, koszty zmienne są natomiast bardzo małe. Tę unifikację nazywa się dalej unifikacją silną w ustrojowej reformie rynku energii elektrycznej.

Oczywiście, unifikacja silna struktury kosztów domaga się unifikacji pochodnej systemów cenotwórstwa w obszarze opłat sieciowych i wytwarzania energii, dotychczas całkowicie odmiennych. Z drugiej jednak strony unifikacja silna struktury kosztów nie oznacza, że kończą się kłopoty, i że reguły cenotwórstwa na rynku wschodzącym 1) mogą być wypracowane w całości w trybie wyprzedzających spekulacji myślowych, poza mechanizmami samouczącego się rynku konkurencyjnego.

Tabela 9. Segment prosumencki na mapie analizy potencjału wykorzystania zasady TPA+

\begin{tabular}{|c|c|c|}
\hline & \multicolumn{2}{|l|}{ Prosument } \\
\hline & jednowęzłowy & wielowęzłowy \\
\hline \multirow[t]{2}{*}{ Nazwa prosumenta } & $\begin{array}{l}\text { Gospodarstwo domowe } \\
\text { w domu jednorodzinnym }\end{array}$ & Samorząd (w zakresie zadań własnych) \\
\hline & Przedsiębiorca MMSP & Sieć biznesowa (sklepów, hoteli, inne) \\
\hline Osłona OK & $\begin{array}{l}\text { OK } 1 \text { - dominująca } \\
\text { (w tendencji } 7 \mathrm{mln} \text { ) }\end{array}$ & $\begin{array}{l}\text { OK1 - węzłowa } \\
\text { OK2 - węzłowa } \\
\text { OK } 3 \text { - wirtualna na sieci archipelag } 1 \text { lub } 2\end{array}$ \\
\hline Opłata sieciowa & $\begin{array}{l}\mathrm{NM} \text { - dominująca } \\
\mathrm{RE} \text { - niszowa }\end{array}$ & NM, RE - zrównoważone \\
\hline Terminal STD & Węzłowy (hardwarowo-softwarowy) & $\begin{array}{l}\text { Sieć terminali węzłowych (hardwarowo-softwarowych) } \\
\text { Terminal wirtualny (algorytmiczny, softwarowy) }\end{array}$ \\
\hline Platforma OIRE & Nie ma krytycznego znaczenia & Wymagania względem platformy - umiarkowane \\
\hline
\end{tabular}

Ta silna unifikacja oznacza natomiast dwie sprawy. Po pierwsze, do unifikowania mechanizmów konkurencji miedzy sieciami i źródłami wystarczająca jest jednakowa stopa zwrotu kapitału (i tę unifikację dalej nazywa się słaba). Jest tak, bo koszty zmienne nie wprowadzają zakłóceń do konkurencji. Ponadto, oprócz unifikacji struktury kosztów (unifikacji silnej), występuje wiele unifikacji obszarów sieciowego i wytwórczego na rynku wschodzącym 1), które nazywa się unifikacjami warunkującymi unifikację słabą (np. czasy życia sieci i źródeł są zbliżone, porównywalne są także 
nakłady inwestycyjne na sieci i źródła). W jednym i drugim obszarze biznesowym (usług sieciowych i wytwarzania energii) oprócz unifikacji słabej (stopy zwrotu kapitału) ważna oczywiście jest ochrona płynności finansowej; jej unifikacja ma jednak, w świetle przedstawionych uwag, całkowicie naturalny charakter (jest to unifikacja pochodna unifikacji słabej).

Po drugie, przyczyna znaczenia cenotwórstwa czasu rzeczywistego na rynku wschodzącym 1) przenosi się w całkowicie nowe obszary (względem tego, co jest na rynku schodzącym WEK). Przenosi się w obszar dostępności energii elektrycznej ze źródeł wytwórczych OZE cechujących się produkcją wymuszoną oraz w obszar zarządzania popytem na usługi energetyczne, wszystkie, realizowane w modelu monizmu elektrycznego OZE.

W tym miejscu następuje kulminacja rozważań teoretycznych unifikacji końcowego rynku wschodzącego 1) energii elektrycznej, a mianowicie dojście do superunifikacji. Ta odnosi się do konkurencji między: źródłami wytwórczymi OZE (zarówno cechującymi się produkcją wymuszoną jak i biogazowymi źródłami bilansująco-regulacyjnymi), sieciami nN-SN oraz usługami systemowymi rynku wschodzącego 1).

Praktycznie zerowe koszty zmienne źródeł PV i wiatrowych powodują daleko idące konsekwencje. Przede wszystkim bardzo dużą zmienność cen krótkookresowych - na rynku pojawiają się ceny bliskie zera; w okresie transformacji, kiedy pracują jeszcze bloki węglowe, i zwłaszcza jądrowe, ceny mogą się mocno „osuwać” w strefę cen ujemnych. To właśnie takie ceny sa (pod warunkiem, że architektura i mechanizmy rynku są dobrze zunifikowane) egzekutorem niezbędnej alokacji zasobów w procesie transformacji całej energetyki do monizmu elektrycznego OZE (w źródłach wytwórczych węglowych, a zwłaszcza gazowych jest odwrotnie: koszty zmienne są duże, koszty stałe mniejsze, a nawet znacznie mniejsze).

Tabele 7, 8 i 9 zestawione z doraźnie wprowadzanymi regulacjami prawnymi pod wpływem doraźnych interesów politycznych pokazują wagę unifikacji końcowego rynku wschodzącego 1) energii elektrycznej: segmentu źródeł OZE, sieciowego (opłat sieciowych), usług systemowych (regulacyjnych i bilansujących). W tym kontekście na dużą uwage zasługuje net metering, czyli system barterowy wymiany (rozliczania) energii elektrycznej na osłonie bilansowej (prosumenta, wirtualnego mikro- lub mini-systemu elektroenergetycznego WSE) i KSE. Stąd wynika, że system ten integruje opłatę za użytkowanie sieci i za usługi systemowe KSE (dostarczane przez operatora OSP). 
Tabela 10. Segment systemów WSE na mapie analizy potencjału wykorzystania zasady TPA+

\begin{tabular}{|c|c|c|}
\hline & \multicolumn{2}{|c|}{ System WSE } \\
\hline & WHSE & WmSE \\
\hline \multirow{3}{*}{ Nazwa WSE } & $\begin{array}{l}\text { WHSE w środowisku spółdzielni/ wspólnoty } \\
\text { mieszkaniowej, dewelopera mieszkaniowego }\end{array}$ & $\begin{array}{l}\text { WmSE w postaci klastra energetycznego } \\
\text { (zgodnego z ustawą OZE lub innego) }\end{array}$ \\
\hline & $\begin{array}{l}\text { WHSE w środowisku } \\
\text { dewelopera mieszkaniowego }\end{array}$ & $\begin{array}{l}\text { WmSE w postaci spółdzielni energetycznej } \\
\text { (zgodnej z ustawą OZE lub innej) }\end{array}$ \\
\hline & $\begin{array}{l}\text { WHSE na wsi z mikroelektronią biogazową } \\
\text { w średniotowarowym gospodarstwie rolnym } \\
\text { (lub inny) }\end{array}$ & $\begin{array}{l}\text { WmSE w postaci elektrowni wirtualnej (nale- } \\
\text { żącej do inwestora z sektora MSP) }\end{array}$ \\
\hline \multirow{3}{*}{ Osłona OK } & \multirow{3}{*}{$\begin{array}{l}\text { OK } 1 \text { - dominująca } \\
\text { (w tendencji } 7 \mathrm{mln} \text { ) }\end{array}$} & $\mathrm{OK}_{1}$ \\
\hline & & $\mathrm{OK}_{2}$ \\
\hline & & $\mathrm{OK}_{3}$ - wirtualna \\
\hline \multirow{2}{*}{$\begin{array}{l}\text { Opłata } \\
\text { sieciowa } \\
\text { NM, RE }\end{array}$} & NM - dominująca & \multirow{2}{*}{ NM, RE - zrównoważone } \\
\hline & $\mathrm{RE}$ - niszowa & \\
\hline \multirow{2}{*}{ Terminal STD } & & Węzłowy \\
\hline & & Wirtualny (algorytmiczny) \\
\hline \multicolumn{2}{|c|}{ Platforma OIRE Nie ma krytycznego znaczenia } & Wymagania względem platformy - wysokie \\
\hline
\end{tabular}

W obecnej postaci (w Polsce wynikającej z ustawy OZE) jest to system całkowicie arbitralny (przy tym ustawa nie zawiera pojęcia net metering, określa natomiast system rozliczeń prosumenta). Mianowicie, ma postać statycznego „taryfowego/ustawowego” współczynnika net meteringu, dalej nazywanego współczynnikiem WNM (w ustawie OZE stosuje się nazwę upust), mającego na celu masowe pobudzenie inwestycji prosumenckich w źródła PV (nowelizacja ustawy OZE z połowy 2016 roku) oraz w rozwój spółdzielni energetycznych na obszarach wiejskich inwestujących (to jest autorska hipoteza) w źródła PV, pojedyncze elektrownie wiatrowe oraz biogazowe mikroelektrownie i elektrownie bilansujace (a nawet regulacyjne) z zasobnikami biogazu.

Teoretyczny potencjał systemu jest, w kontekście rozwoju rynku RCR, bardzo wielki. Wykorzystanie potencjału do wzmacniania efektywnej konkurencji między rynkiem schodzącym WEK i rynkiem RCR wymaga przejścia do net meteringu dynamicznego i dobrej kalibracji dynamicznego współczynnika WNM. Nie da się jednak tego osiagnaćć 
bez odejścia od praktyki mnożenia coraz bardziej nieprzejrzystych - tym samym destrukcyjnych - arbitralnych regulacji będących wynikiem dotykającej Polskę doraźnej gry interesów i bez przezwyciężenia deficytu kompetencji na poziomie państwa potrzebnych do modelowania architektury i mechanizmów rynku czasu rzeczywistego RCR.

W wypadku drugiego systemu, roamingu energetycznego, zasada TPA+ jest dostępem do sieci nN-SN i dostępem do usług systemowych KSE, wyodrębnionych, lub nie (ewentualne „rozdzielne” traktowanie tych dwóch dostępów odnosi się tylko do systemów ich cenotwórstwa, dostęp do sieci nN-SN zawsze pociaga natomiast za sobą wymagalność dostępu do usług systemowych KSE). Niezależność cenotwórcza, a z drugiej strony dostęp do sieci pociąający za sobą wymagalność dostępu do usług systemowych, traktowane łącznie, określają 3-segmentową architekturę przedmiotową rynku RCR.

Tymi segmentami są: $1^{\circ}$ - wytwarzanie (źródła z kanonicznego zbioru technologii wytwórczych OZE), $2^{\circ}$ - sieci nN-SN (dwa systemy opłaty za dostęp do tych sieci i za ich użytkowanie, mianowicie net metering oraz roaming energetyczny i za dostęp za ich pośrednictwem do usług systemowych KSE, $3^{\circ}$ - usługi bilansujące na rynku RCR (głównie u prosumentów przebudowujących własna gospodarkę energetyczną do monizmu elektrycznego OZE).

W sposób całkowicie odrębny (mający status obligatoryjności) zasada TPA+ określa dostęp do regulacji częstotliwościowej (regulacja pierwotna i wtórna), realizowanej za pomoca jednostek wytwórczych centralnie dysponowane (JWCD) w KSE oraz za pomoca zasobów tej regulacji osiagalnych (przez operatora OSP) na jednolitym rynku europejskim za pomocą połączeń transgranicznych. Regulacja częstotliwościowa jest współcześnie w KSE realizowana w dominującym zakresie za pomocą bloków węglowych. Jednak rozpoczął się już proces partycypacji elektrowni wiatrowych w tej regulacji. Tym samym rozpoczął się proces „przenoszenia” regulacji częstotliwościowej (najbardziej specjalistycznej usługi systemowej) z rynku schodzącego WEK na rynki wschodzące 1) i 2). 


\section{Załącznik 3. Oszacowania}

(pięć oszacowań kanonicznych polskiej transformacji energetycznej do monizmu elektrycznego OZE 2050)

Kanoniczne oszacowania potrzebne do zaprojektowania reformy energetyki zapewniającej jej (energetyki) transformację do monizmu elektrycznego OZE 2050 obejmują: $1^{\circ}$ - bilanse energetyczne: wyjściowy 2019 i antycypowany $2050,2^{\circ}$ - koszty roczne 2019 i 2050 zaspokojenia potrzeb energetycznych kraju, $3^{\circ}$ - skumulowane nakłady inwestycyjne (podkreśla się, że nie są to „koszty”) na transformację energetyki do monizmu elektrycznego OZE (potrzebne do zrealizowania pierwszego pełnego cyklu życia technologii umożliwiających monizm), $4^{\circ}$ - skumulowane oszczędności (nadwyżki) 2019-2050 w procesie transformacji energetyki do monizmu elektrycznego OZE 2050, $5^{\circ}$ - podział skumulowanej nadwyżki na mikro- i makroekonomiczne „,samofinansowanie" się transformacji energetyki do monizmu elektrycznego OZE.

Bardzo uproszczone oszacowania, mające bezpośrednie i pośrednie powiązania z zasobami wiedzy na Powszechnej Platformie Transformacyjnej Energetyki 2050 (http://www.ppte2050.pl), podajemy poniżej.

\section{Ramowe (krajowe 2019, 2050) roczne bilanse energetyczne}

Na krajowy bilans energetyczny 2019 (poza surowcowym/procesowym wykorzystaniem paliw kopalnych) składają się, w wielkim uproszczeniu: energia pierwotna (chemiczna) paliw kopalnych równa 1100 TWh (węgiel kamienny - 500 TWh, węgiel brunatny - $250 \mathrm{TWh}$, ropa naftowa - $250 \mathrm{TWh}$, gaz ziemny - $100 \mathrm{TWh}$ ) oraz wytworzona z niej energia końcowa (powiększona o 15 TWh energii elektrycznej wyprodukowanej w źródłach OZE) równa 600 TWh (energia elektryczna - 170 TWh brutto i 130 TWh netto, ciepło - 210 TWh brutto, paliwa transportowe -220 TWh brutto).

$\mathrm{Na}$ antycypowany bilans monizmu elektrycznego $2050 \mathrm{w}$ bardzo wielkim przybliżeniu składają się: energia napędowa elektryczna OZE netto równa 175 TWh (brutto równa $200 \mathrm{TWh}$ ), energia użyteczna $205 \mathrm{TWh}$ (energia napędowa elektryczna OZE netto pomniejszona o $15 \mathrm{TWh}$ potrzebnych do zasilania pomp ciepła i powiększona o 45 TWh ciepła produkowanego przez te pompy na potrzeby grzewcze i produkcji ciepłej wody użytkowej). 
Zostanie to osiagnięte za pomoca: wzrostu efektywności w dotychczasowych (tradycyjnych) obszarach użytkowania energii elektrycznej ( $30 \%)$, a dalej za pomocą technologii domu pasywnego (5-krotne zmniejszenie zapotrzebowania na ciepło grzewcze w budownictwie), za pomoca pompy ciepła (3-krotne zwiększenie ciepła użytecznego w stosunku do elektrycznej energii napędowej) i za pomocą samochodu elektrycznego (3-krotnie wyższa sprawność w stosunku do samochodu z silnikiem spalinowym).

\section{Ramowe (krajowe 2019, 2050) roczne koszty zaspokojenia potrzeb energetycznych}

Podstawą do oszacowania kosztów rocznych 2019 zaspokojenia potrzeb energetycznych kraju jest bilans energii końcowej i przeciętne ceny jednostkowe poszczególnych rodzajów energii (uwzględniające podatki i parapodatki). Tak oszacowane wynoszą one 200 mld PLN.

Podstawą do oszacowania bazowych rocznych kosztów 2050 zaspokojenia potrzeb energetycznych kraju w modelu monizmu elektrycznego OZE jest bilans energii napędowej elektrycznej OZE i amortyzacja źródeł OZE uwzględniająca ich strukturę technologiczna. Racjonalna (antycypowana na obecnym etapie komercjalizacji technologii) polska struktura wytwórcza energii napędowej OZE 2050 (udziały procentowe) ma postać: 5 - (10-15) - (20-25) - 30 - 30; podane udziały odnoszą się do następujących technologii wytwórczych, odpowiednio: mikroelektrownie biogazowe $(\mu \mathrm{EB})$, elektrownie biogazowe (EB), elektrownie wiatrowe lądowe (EWL), źródła PV dachowe (PV), elektrownie wiatrowe morskie (EWM).

Uwzględniając przedstawioną strukturę źródeł i ceny (nakłady jednostkowe) 2019 dla poszczególnych technologii wytwórczych uzyskuje się oszacowanie bazowych kosztów 2050 zaspokojenia potrzeb energetycznych wynoszące 20 mld PLN (w cenach stałych, poziom cen 2019). Dla oszacowania całkowitych kosztów 2050 wykorzystuje się (autorski) współczynnik zwiększający koszty bazowe równy 2; współczynnik uwzględnia wymagany „margines” zdolności wytwórczych źródeł, amortyzację silnie zredukowanej (w modelu monizmu elektrycznego OZE) infrastruktury sieciowej, amortyzacje inteligentnej infrastruktury oraz koszty serwisowe i zarządcze całej infrastruktury wytwórczo-dostawczej monizmu elektrycznego OZE. Po zastosowaniu tego współczynnika całkowite koszty 2050 zaspokojenia potrzeb energetycznych kraju wynoszą $40 \mathrm{mld}$ PLN (poziom cen 2019). 


\section{Skumulowane (2020 do 2050) bazowe krajowe nakłady inwestycyjne}

Skumulowane bazowe nakłady inwestycyjne niezbędne do realizacji modelu monizmu elektrycznego OZE 2050 szacuje się na poziomie 500 mld PLN (poziom cen 2019). Oszacowanie to respektuje następujące uwarunkowania: $1^{\circ}$ - zapotrzebowanie na energię napędową brutto wynosi 200 TWh (p.1), $2^{\circ}$ - struktura wytwórcza jest taka, jak w p. 2, $3^{\circ}$ - energia napędowa brutto i struktura wytwórcza implikują następująca bazowa strukturę mocy źródeł wytwórczych: $\mu \mathrm{EB}$ - 1,3 GW, EB - (2,5-3,7) GW, EWL - (1316) GW, PV - $60 \mathrm{GW}, \mathrm{EWM}$ - $15 \mathrm{GW}, 4^{\circ}$ - rynkowe jednostkowe nakłady inwestycyjne 2019 dla poszczególnych źródeł (technologii wytwórczych) wynoszą: $\mu \mathrm{EB}-(250,750)$ tys. PLN za mikroelektrownię o mocy podstawowej $(10,50) \mathrm{kW}, \mathrm{EB}-13 \mathrm{mln}$ PLN za elektrownię o mocy podstawowej $1 \mathrm{MW}$, EWL - 2,1 mln $€ / \mathrm{MW}, \mathrm{PV}-1$ tys. $€ / \mathrm{kW}$, EWM (z wyprowadzeniem na ląd) $-2,5 \mathrm{mln} € / \mathrm{MW}$.

Dla oszacowania skumulowanych całkowitych nakładów inwestycyjnych niezbędnych do realizacji modelu monizmu elektrycznego OZE 2050 wykorzystuje się (autorski) współczynnik zwiększający nakłady bazowe równy 1,5 (współczynnik uwzględnia wymagany „margines” zdolności wytwórczych źródeł oraz nakłady inwestycyjne na silnoprądową infrastrukturę sieciową i inteligentną systemową infrastrukturę zarządcza). Zatem skumulowane całkowite nakłady inwestycyjne niezbędne do realizacji modelu monizmu elektrycznego OZE 2050 wynoszą 750 mld PLN (poziom cen 2019).

Podkreśla się, że tak oszacowane skumulowane całkowite nakłady inwestycyjne odnoszą się do pierwszej kompletnie zrealizowanej „pętli” inwestycyjnej reelektryfikacji OZE. Jest to oczywiście pętla sprzężona bardzo silnie z transformacją polskiej energetyki 2019 do monizmu elektrycznego OZE 2050. Jednak osi czasowe reelektryfikacji OZE i transformacji do monizmu elektrycznego OZE 2050 nie są tożsame. W szczególności, pierwsza pętla inwestycyjna reelektryfikacji OZE (realizowanej poza energetyką wodna) rozpoczęła się już w roku 2005. I będzie się kończyć wraz z upływem czasu życia nowych technologii (który wynosi 20-25-30 lat), czyli często przed upływem roku 2050.

\section{Skumulowane (2020 do 2050) krajowe oszczędności w procesie transformacji energetyki do monizmu elektrycznego OZE}

Oszczędności te oblicza się jako sumę różnic rocznych kosztów zaspokajania wszystkich potrzeb energetycznych na dwóch trajektoriach mających wspólny początek 2019. Sa to: trajektoria „kontynuacji” wynikająca z polityki PEP 2040 oraz trajektoria 
transformacji przełomowej do monizmu elektrycznego OZE 2050. Początkowe (2019) roczne koszty zaspokojenia wszystkich potrzeb energetycznych, jednakowe dla obydwu trajektorii, wynoszą 200 mld PLN (p. 2).

W wypadku polityki PEP 2040 jest to zarazem koszt 2050 pokrycia zapotrzebowania na paliwa (węgiel - $40 \mathrm{mln}$ ton, paliwa transportowe - $26 \mathrm{mln}$ ton, gaz ziemny $22 \mathrm{mld}$ $\mathrm{m}^{3}$ ) powiększony o podatki, opłaty za emisje $\mathrm{CO}_{2}$ oraz o koszty kapitałowe niezamortyzowanych elektrowni jądrowych (w oszacowaniach uwzględniono, że wszystkie inwestycji wielkoskalowe energetyki WEK - elektroenergetyki, sektora paliw płynnych i gazownictwa - poza elektrowniami jądrowymi będą w horyzoncie 2050 spłacone i zamortyzowane).

Uwzględniając początkowe (2019) roczne koszty zaspokojenia wszystkich potrzeb energetycznych na poziomie $200 \mathrm{mld}$ PLN, a końcowe (2050) na poziomie $200 \mathrm{mld}$ PLN w wariancie polityki PEP 2040 oraz $40 \mathrm{mld}$ PLN w wariancie transformacji do monizmu elektrycznego OZE (p. 2) skumulowaną różnicę kosztów w horyzoncie 2050 szacuje się na około 2 bln. PLN na korzyść monizmu elektrycznego. (Jest to oszacowanie „wywoławcze”, mające na celu wywołanie szerszego zainteresowania transformacja energetyki do monizmu elektrycznego OZE 2050 i pobudzenie badań nad taka transformacja. Ma charakter ekspercki. Zostało zrobione głównie w środowisku funkcji wykładniczych, z wykorzystaniem daleko idącej linearyzacji odcinkowej procesów transformacyjnych).

\section{Rynkowa alokacja nadwyżki skumulowanych oszczędności nad potrzebnymi skumulowanymi nakładami inwestycyjnymi na reelektryfikację OZE}

Oszacowania rynkowej alokacji nadwyżki skumulowanych oszczędności (2 bln PLN, p. 4) nad potrzebnymi skumulowanymi nakładami inwestycyjnymi na reelektryfikacje OZE (750 mld PLN, p.3) uprawnia hipotezę roboczą, że istnieją bardzo silne podstawy mikro- i makroekonomicznego rynkowego „samofinansowania” się (z pełną ochroną „płynności finansowej”) transformacji obecnej energetyki WEK do monizmu elektrycznego OZE 2050, w tym sfinansowania w niezbędnym zakresie programu sprawiedliwej transformacji.

Ze środków uwalnianych sukcesywnie w procesie ograniczania zużycia paliw kopalnych i zakupu dóbr inwestycyjnych dla energetyki WEK (jednych i drugich pochodzacych w dominującej części z importu), rynkowo najbardziej „płynnych”, można w pełni 
sfinansować reelektryfikację OZE (kosztującą nie więcej niż 750 mld PLN). Dalej pasywizację zasobów budowlanych (obejmujących obecnie $6 \mathrm{mln}$ domów jednorodzinnych oraz 6 mln mieszkań w 450 tys. budynków wielorodzinnych) kosztującą nie więcej niż 500 mld PLN (20\% wartości zasobów mieszkaniowych Polaków wycenianych przez rynek na około 2,5 bln PLN). Reelektryfikację budownictwa (kosztującą nie więcej niż 350 mld PLN potrzebnych na inwestycje w systemy ciepłownicze bazujące na pompach ciepła. Wreszcie na reelektryfikację transportu (kosztującą nie więcej niż 200 mld PLN, potrzebnych do pobudzenia transformacji 20-milionowego rynku samochodów poprzez jednostkowe wsparcie zakupu wynoszące 10 tys. PLN dla pierwszych 5 milionów samochodów elektrycznych).

Zatem na program sprawiedliwej transformacji całej energetyki paliw kopalnych WEK „pozostaje” 200 mld PLN. Jest to „niewiele” w świetle dotychczasowych kosztów restrukturyzacji górnictwa węgla kamiennego, znacznie „mniejszego” od całej energetyki: na około 200 mld PLN oceniane jest (WiseEuropa) wsparcie górnictwa (bezpośrednie i pośrednie) tylko w okresie 1990-2016.

Ta dysproporcja daje się jednak racjonalizować. Filarem takiej racjonalizacji są następujące trzy uwagi. Restrukturyzacja górnictwa nie stworzyła żadnego koła zamachowego gospodarki, w tym nie pobudziła rynku pracy i nie ograniczyła importu (paliw i dóbr inwestycyjnych), a wielkie wsparcie górnictwa wynikało z jego wielkiej historycznej siły politycznej (i zostało bezkrytycznie przeniesione do współczesnej rzeczywistości). Transformacja energetyki paliw kopalnych do monizmu elektrycznego OZE jest natomiast kołem zamachowym gospodarki, pobudza rynek pracy i ogranicza do zera import paliw, a także ogranicza w zasadniczym stopniu import dóbr inwestycyjnych dla energetyki, mający bardzo istotne znaczenie w imporcie dóbr inwestycyjnych dla całej gospodarki. Zatem transformacja energetyki tworzaca bardzo silne środowisko prorozwojowe, i wytwarzająca nadwyżkę bilansowa, umożliwia w naturalny sposób redukcję kosztów programu sprawiedliwej transformacji. 


\section{Załącznik 4. Weryfikacja wystarczalności sił rynkowych do zrealizowania transformacji energetyki do monizmu elektrycznego OZE 2050}

Wszystkie przedstawione w załączniku 3 oszacowania i sformułowane hipotezy związane z transformacją energetyki do monizmu elektrycznego OZE 2050 wymagają uwiarygodnienia w kontekście wystarczalności sił rynkowych do jej realizacji. W szczególności dostarcza go (uwiarygodnienia) uproszczona weryfikacja dynamiki procesu transformacyjnego w świetle wydolności mechanizmów rynkowych na trzech ścieżkach transformacyjnych.

\section{Reelektryfikacja OZE}

Pierwsza z tych weryfikacji dotyczy reelektryfikacji OZE w horyzoncie 2050. Roczna 8-procentowa dynamika wzrostu rynku wytwórczego wschodzącego 1 energii elektrycznej (z poziomu 12 TWh w roku 2019 do 140 TWh energii elektrycznej brutto) oraz budowa jednej farmy offshore na rynku wschodzącym 2 o mocy 1,4 GW co 3 lata sa wystarczające do wyprodukowania potrzebnej w roku 2050 (w modelu monizmu elektrycznego OZE) energii elektrycznej brutto wynoszącej 200 TWh (energii napędowej $175 \mathrm{TWh})$.

Jest to bardzo wymagająca dynamika, zwłaszcza w wypadku rynku wschodzącego 1), i to zarówno ze względu na roczną stopę wzrostu rynku ( $8,2 \%)$, jak i czas trwania tej dynamiki (aż 30 lat). Podkreśla się jednak, że była to standardowa dynamika elektryfikacji polskiej (a także europejskiej i amerykańskiej) w okresie 30 lat po II wojnie światowej. Różnica jest taka, że elektryfikacja powojenna była realizowana w modelu keynesowskim (co doprowadziło do wynaturzenia elektroenergetyki WEK), reelektryfikacja OZE musi być przeprowadzona rynkowo (do czego podstawę daje współczesne środowisko technologiczne i społeczne).

\section{Paspwizacja i reelektryfikacja budownictwa}

Druga z weryfikacji związana jest z pasywizacją i reelektryfikacją budownictwa w horyzoncie 2050. Punktem wyjścia na tej ścieżce jest obecny roczny rynek budowy nowych mieszkań (w jednej połowie w domach jednorodzinnych, w drugiej w budownictwie wielorodzinnym), wynoszaccy około 150 tys. mieszkań. Roczny 2-procentowy (trwały) wzrost tego rynku w powiązaniu z hipotezą o racjonalności głębokiej rewitalizacji 
połowy istniejących zasobów mieszkaniowych $(3 \mathrm{mln}$ z $6 \mathrm{mln}$ domów jednorodzinnych i $3 \mathrm{mln}$ z 6 mln mieszkań w budynkach wielorodzinnych) oraz o wyburzeniu drugiej połowy tych zasobów, i wreszcie z hipotezą o rocznej 8- procentowej dynamice pasywizacji budownictwa (w obu segmentach budynków: nowych oraz głęboko rewitalizowanych) uprawdopodobnia w wysokim stopniu praktyczną możliwość rynkowej pasywizacji całego budownictwa mieszkaniowego i elektryfikacji ciepłownictwa (w zakresie potrzeb grzewczych i produkcji ciepłej wody. Podkreśla się tu, że ilościowy potencjał wzrostowy zasobów mieszkaniowych jest w Polsce bardzo niewielki (ze względu na trwająca depopulację kraju).

\section{Reelektryfikacji transportu}

Trzecia ścieżka dotyczy reelektryfikacji transportu. Półmilionowy roczny rynek sprzedaży nowych samochodów racjonalizuje hipotezę, że pełna elektryfikacja transportu samochodowego w horyzoncie 2050 jest bardzo racjonalna (liczba samochodów w roku 2019, to około 20 mln i jest to liczba, która nie ma już praktycznego potencjału wzrostowego, przeciwnie będzie spadać). 


\section{Załącznik 5. Definicje (dwie fundamentalne, jedna kanoniczna transformacyjna i trzy krytyczne startowe)}

Transformacja energetyki do monizmu elektrycznego OZE 2050, potrzebująca swojej metody badawczej, potrzebuje przede wszystkim, bardzo pilnie, definicji (słownictwa). Sześć przytoczonych definicji otwiera zbiór (zapewne wielki i długo jeszcze otwarty) definicji, których celem jest wiązanie (w roboczym procesie) budowy metody badawczej i działań praktycznych.

Z drugiej strony są to definicje, które mają od zaraz ułatwiać konwergencję dwóch nurtów edukacyjnych. Reedukacyjnego (który muszą przejść kadry starej energetyki) i budowy od podstaw nowych kompetencji potrzebnych do przeprowadzenia transformacji energetyki do monizmu elektrycznego OZE za pomocą ustrojowej reformy rynku energii elektrycznej.

\section{Transformacja energetyki ponad podziałami}

Oznacza (definicja ogólna) program realizowany ponad podziałami politycznymi, ale przede wszystkim powszechny program społeczno-gospodarczy, mobilizujący całe społeczeństwo do zbudowania swojej podmiotowości w nowej (XXI-wiecznej) cywilizacji.

\section{Monizm elektryczny OZE}

Pojęcie oznaczające jedyność energii elektrycznej ze źródeł OZE w zaspakajaniu potrzeb energetycznych - wszystkich, którzy je maja - wywiedzione z tripletu paradygmatycznego transformacji energetycznej, mianowicie z paradygmatów: prosumenckiego, egzergetycznego i wirtualizacyjnego).

Twardym paradygmatem jest paradygmat egzergetyczny (paradygmaty prosumencki i wirtualizacyjny są paradygmatami eklektycznymi: prosumencki działa w obszarze ekonomii i procesów społecznych, wirtualizacyjny określa siłę inteligentnej infrastruktury w obszarze organizowania nowego rynku energii elektrycznej, mianowicie zmienia sposób wykorzystania sieci elektroenergetycznych użytkowania energii elektrycznej).

Paradygmat egzergetyczny jest osadzony na fundamentalnych prawach termodynamiki (entropia, egzergia) oraz elektrotechniki (elektromagnetyzm), które doczekały się sprzyjających im technologii i dzięki temu przyszedł czas na ich pełne wykorzystanie (wcześniej wykorzystanie tych praw było ograniczone ze względu na brak technologii; 
potrzebne technologie pojawiły się dopiero w wyniku osiagnięć elektroniki i mikroelektroniki oraz inżynierii materiałowej).

Prawa, z których jest wywiedziony triplet paradygmatyczny, są prawami najprostszymi, a zatem najpowszechniej działającymi. Stąd, że są fundamentalne wynika, że są najtrwalsze, czyli najdłużej przetrwają. A jeśli rozwój technologii osiagnął poziom umożliwiający ich efektywne (ekonomiczne) wykorzystanie, to niemoralne jest dalsze opóźnianie transformacji energetyki względem trajektorii kształtowanej przez konkurencję na rynku energii elektrycznej.

\section{Dekompozүcja bezpieczeństwa elektroenergetycznego}

Dekompozycja bezpieczeństwa elektroenergetycznego jest warunkiem funkcjonowania rynku wschodzącego 1) energii elektrycznej. Polega ona na zasadniczym odejściu od zasady obowiązującej na „równoległym” rynku schodzącym WEK. Na rynku wschodzącym 1) na podziale odpowiedzialności za bezpieczeństwo między operatorów (odpowiadają oni tylko za bezpieczeństwo infrastruktury sieciowej i systemowej) oraz konkurencyjny rynek energii elektrycznej czasu rzeczywistego (rynek RCR); w taki właśnie rynek będzie się przekształcał w tendencji rynek wschodzący 1). Zatem ten ostatni jest przeznaczony dla wszystkich, którzy maja potrzeby energetyczne i chcą je zaspakajać korzystać z konkurencji, godząc się jednocześnie na to, że operatorzy sieciowi mają prawo (i stosuja je) do ograniczania dostaw energii elektrycznej w zakresie wynikającym z zasady TPA+.

Istotą tej zasady jest właściwa segmentacja rynku wschodzącego 1) w kontekście dostępu do sieci nN-SN i zasobów wytwórczo-bilansujących hurtowego rynku schodzącego WEK (funkcjonującego na infrastrukturze sieciowej 400-220-110 kV między osłonami OK4 i OK5.

\section{Zasada TPA+}

Właściwą segmentację rynku wschodzącego 1) zapewniają stworzone w trybie regulacji prawnych trzy platformy stanowiące przedmiot zasady TPA+. Sa to: $1^{\circ}$ - platforma prosumencka, $2^{\circ}$ - różnorodne platformy podmiotowo-przedmiotowe przybierające postać wirtualnych systemów elektroenergetycznych (WSE), $3^{\circ}$ - różnorodne platformy handlowe. Zarówno prosumenci jak i systemy WSE oraz platformy handlowe sa przyłaczone na mocy zasady TPA+ do sieci za pomocą swoich terminali STD, które umożliwiają 
konkurencyjny handel „ponad siecią”, w granicach „wydolności” sieci nN-SN i zasobów rynku hurtowego. Opłaty sieciowo-systemowe w środowisku dekompozycji bezpieczeństwa elektroenergetycznego i zasady TPA+ są powiązane z rzeczywistym (fizycznym) wykorzystaniem sieci i usług systemowych (nie jest dopuszczona socjalizacja kosztów operatorskich, w szczególności za pomocą ich uśredniania na duże wielonapięciowe obszary sieciowe).

\section{Net metering}

Jest to system rozliczeń: $1^{\circ}$ - prosumenta przyłączonego do systemu KSE za pomoca sieci elektroenergetycznej nN-SN, $2^{\circ}$ - systemu WME (wirtualny mikro-, mini-system elektroenergetyczny) korzystającego z sieci nN-SN oraz z usług systemowych KSE. W wypadku prosumenta rozliczenia są realizowane na osłonie węzłowej (rzeczywistej, pomiarowej), w wypadku systemu WME na osłonie wirtualnej (algorytmicznej). Na ogól system jest wprowadzany ustawowo do stosowania na rynku energii elektrycznej.

W Polsce system jest przedmiotem ustawy OZE - nowelizacje: 2016 (nowelizacja odnosząca się do prosumenta) oraz nowelizacja 2019, w toku (odnosząca się do systemu WME na obszarach wiejskich należącego do wiejskiej spółdzielni energetycznej).

Istotą systemu rozliczeń jest współczynnik WNM (współczynnik net meteringu). Jest on stosowany w następujący sposób: za energię $\mathrm{E}_{\mathrm{w}}$ (wprowadzoną „darmowo” do sieci, do KSE) prosument (spółdzielnia energetyczna) w okresie rozliczeniowym (rocznym) otrzymuje ekwiwalent $\mathrm{E}_{\mathrm{p}}=\mathrm{WNM} \cdot \mathrm{E}_{\mathrm{w}}$ (energia „darmowo” pobrana z sieci, z KSE). Jest to zatem wymiana barterowa: prosument (spółdzielnia energetyczna) za energię $\mathrm{E}_{\mathrm{w}}$ wprowadzoną do sieci pobiera z sieci energię $\mathrm{E}_{\mathrm{p}}$.

Wartość współczynnika WNM wprowadzanego w Polsce w trybie regulacji prawnej (0,8 dla źródła prosumenckiego o mocy do $10 \mathrm{~kW}$ oraz 0,7 dla źródeł do $50 \mathrm{~kW}$ i 0,6 dla systemu WME będącego własnością spółdzielni energetycznej) ma charakter całkowicie arbitralny. Spełnia przy tym kryteria zdroworozsądkowe w wypadku wąskiej klasy prosumenckich źródeł PV w segmencie domów jednorodzinnych, ale nie spełnia takich kryteriów (jest zbyt niski) w wypadku systemów WSE ze źródłami PV, pojedynczymi elektrowniami wiatrowymi oraz biogazowymi mikroelektrowniami i elektrowniami bilansującymi (a nawet regulacyjnymi) z zasobnikami biogazu. 
Dynamiczny net metering. Analiza teoretyczna net meteringu, jeśli zostanie zrealizowana (na platformie PPTE sa jedynie zaczątki takiej analizy), ujawni ustrojowy potencjał tego systemu jako ekwiwalentu opłat systemowo-sieciowych, lub (w innym kontekście) ekwiwalentu magazynu wirtualnego. Wykorzystany w jednym i/lub drugim kontekście w postaci dynamicznej może on w kolejnych latach kształtować efektywnie konkurencję między starą energetyką WEK (rynkiem schodzącym energii elektrycznej 1) oraz nową energetyką OZE (rynkiem wchodzącym energii elektrycznej 1) funkcjonującym na infrastrukturze sieciowej $\mathrm{SN}-\mathrm{nN}$ ). Mówiąc inaczej, efektywną konkurencję między sieciami (łącznie z usługami systemowymi na rynku schodzącym 1) oraz prosumenckimi źródłami OZE i systemami DSR/DSM (łącznie z rozproszonymi prosumenckimi systemami magazynowania).

Dynamiczny net metering polega na dynamicznej zmianie współczynników rozliczeniowych (WNM) w tym systemie, co jest warunkiem prawidłowej - w kategoriach rynkowych - wyceny energii wprowadzanej przez prosumenta do KSE i pobieranej z KSE. Sprowadza się to np. do tego, że za wprowadzoną jednostkę energii w stanie deficytu w KSE użytkownik może pobrać większą energię w dolinie. Czyli współczynnik WNM w stanie deficytu w KSE może przyjmować wartości większe od 1.

\section{Roaming elektroenergetyczny}

Opłata sieciowa, której istota jest podział na dwie części: część, którą płaci odbiorca (w węźle poboru energii), oraz część, którą płaci wytwórca (w węźle wytwórczym), za każdym razem tylko za sieć do punktów spływu (czyli za sieć wykorzystaną fizycznie.

Stawia się hipotezę robocza, że praktyczny system opłat sieciowych w systemie roamingu elektroenergetycznego będzie wynikiem przetwarzania kosztów (rocznych) operatorów w składowe (sieciowe) cen energii elektrycznej na jednotowarowym rynku czasu rzeczywistego. Zatem roaming elektroenergetyczny jest na takim rynku fundamentalnym środowiskiem konkurencji inwestycyjnej między źródłami i sieciami na wszystkich poziomach napięciowych (realizuje kanoniczną zasadę równości kosztów krańcowych krótko- i długo-terminowych). Jest tak dlatego, że zakres stosowania roamingu elektroenergetycznego jest ograniczony do obszarów sieciowych mających dostateczne zdolności przesyłowe (a wzrost zdolności przesyłowych wymaga inwestycji). Na przykład brak dostatecznych zdolności przesyłowych połączeń transgranicznych ogranicza jednolity unijny roaming elektroenergetyczny (dzieli rynek europejski na strefy cenowe). 


\section{Załącznik 6. Energetyka przed wielką (upraszczającą) racjonalizacją metod badawczych, wzorów i jednostek (racjonalizacja bilansów energetycznych, racjonalizacja jednostek energii)}

Energetyka paliw kopalnych jest zdominowana przez jej specyficzne metody i opisy, podporządkowane bardzo silnym różnorodnym uwarunkowaniom mającym źródło w jej (energetyki paliw kopalnych) wielkiej złożoności. W zakresie podstaw fizycznych jest to przede wszystkim złożoność termodynamiki technicznej oraz elektrotechniki stosowanej (będących działami fizyki) i oczywiście wszystkich dyscyplin spokrewnionych.

W zakresie modeli biznesowych jest jeszcze gorzej. Nauka na tym polu w dużym stopniu abdykowała. To grupy interesów decydują w podstawowym stopniu o stosowanych modelach ekonomicznych i opisie stosowanym hermetycznie w poszczególnych sektorach (np. nauki ekonomiczne - nie odnosi się to do indywidualnej działalności poszczególnych ekonomistów - dużych obszarów energetyki, zwłaszcza elektroenergetyki, nigdy nie włączyły dotychczas do przedmiotu swoich badań).

Cywilizacyjny wymiar monizmu elektryczny OZE otwiera drogę do nowego etapu racjonalizacji metod badawczych, wzorów i jednostek w energetyce - racjonalizacji wynikającej z transformacji energetyki. Należy spodziewać się, że coraz bardziej instytucjonalizujący się świat podejmie działania na rzecz takiej racjonalizacji. Będą to zapewne na jednym biegunie działania w postaci podobnej do tych, które zaowocowały utworzeniem w roku 1924 ponadnarodowej organizacji World Energy Council (WEC) i jej raportem Energy for Tomorrow's World (the Realities, the Real Options and the Agenda for Achievement) 1993. Potrzebna obecnie organizacja mogłaby mieć nazwę World Electrical Monism Council (działania na rzecz stworzenia metody monizmu elektrycznego OZE i jej instytucjonalizacji naukowej i administracyjnej są oczywiście sprawą otwarta).

Na drugim biegunie mogą to być działania na rzecz wytworzenia minimalnego (a przynajmniej jakościowo racjonalnego) zbioru niezbędnych definicji (weryfikacja i kontynuacja propozycji przedstawionej w postaci załączniku 4). W kontekście ustrojowej reformy rynku energii elektrycznej szczególnie ważne są dobre definicje wielkości rynkowych; wyjątkowe znaczenie ma nowelizacja, pod kątem rynku wschodzącego 1), systemu definicji energii elektrycznej (i wielkości pochodnych), a także mocy elektrycznej. W kontekście samego monizmu elektrycznego OZE (zaspakajania wszystkich usług energetycznych w tym systemie) ważna jest nowelizacja zaleceń dotyczących stosowania 
jednostek wielkości fizycznych, mianowicie idąca w kierunku bezwzględnego ograniczania odstępstw od stosowania międzynarodowego układu jednostek SI.

\section{Przemiany fazowe, bilanse energetyczne}

Monizm elektryczny OZE redukuje przede wszystkim - w opisach biznesowych (w przekazach politycznych, w powszechnych przekazach społecznych) - trzy rynki końcowe, mianowicie energii elektrycznej, ciepła i paliw transportowych do jednego, energii elektrycznej. Pozwala też na radykalne uproszczenie opisów, które ma fundamentalne uwarunkowanie w postaci przejścia od „długich”, bardzo skomplikowanych termodynamicznych procesów przemian wielofazowych i procesów transportowo-magazynowych paliw kopalnych oraz przesłowo-dystrybucyjnych energii elektrycznej do „krótkich", bardzo prostych dwu-i trzyfazowych.

W energetyce węglowej, jądrowej, ropy naftowej, gazu ziemnego są to łańcuchy przemian obejmujace: wydobycie paliw i ich transport do miejsc przetwarzania; spalanie (ewentualnie reakcję jądrowa), procesy cieplne i pracę mechaniczna, wytwarzanie energii elektrycznej; przesył na duże odległości oraz dystrybucję energii elektrycznej i paliw transportowych do miejsc ich użytkowania (wykorzystania). W monizmie elektrycznym OZE łańcuchy przemian są radykalnie skrócone. W wypadku prosumenckich źródeł PV występują dwie przemiany fazowe (energii promieniowania słonecznego w energię elektryczna, a tej w potrzebną usługę energetyczna). W wypadku źródeł wiatrowych występuja trzy podstawowe przemiany fazowe: energii wiatru w energię kinetyczna, energii kinetycznej w energię elektryczna, a tej w potrzebną usługę energetyczna.

Monizm elektryczny OZE pozwala uniknąć ogromnych strat bogactw naturalnych, którymi sa paliwa kopalne. Straty te ujawnia rozwarcie między zasobami utraconymi (na przykład w wypadku węgla kamiennego zasoby utracone w złożu są w Polsce ponad 2-krotnie większe od zasobów wydobytych), rynkami energii pierwotnej (chemicznej), rynkami końcowymi energii i wreszcie rynkami energii użytecznej.

\section{Rodzaje energii i wielkości zwiqzanych}

Jeszcze ważniejsze jest to, że monizm elektryczny pozwala zredukować wielki zbiór różnorodnych rodzajów energii i wielkości związanych (takich jak ciepło, energia chemiczna, energia jądrowa, entropia, entalpia), którymi trzeba się zajmować w energetyce schodzącej WEK, do tylko energii elektrycznej, jako podstawowej. 


\section{Jednostki energii}

Układ SI, choć formalnie obowiązuje, to w energetyce, zwłaszcza w modelach biznesowych, jest powszechnie naruszany (również w praktyce Unii Europejskiej, w szczególności w dyrektywach i rozporządzeniach). Dzieje się tak ze względu na tradycję, ale przede wszystkim w celu podtrzymywania sektorowego opisu umożliwiającego „,ilosowy” rozwój (pogłębianie nieprzejrzystości biznesu). W wypadku unijnych dyrektyw i rozporządzeń przyczyn należy szukać w nieefektywności zbiurokratyzowanych instytucji w zakresie działań na rzecz nowych kompetencji oraz ich podatności na wpływy grup lobbystycznych).

W rezultacie tylko w wypadku energii (także pracy, ciepła, egzergii) można się doliczyć wielu jednostek głównych/podstawowych (inną sprawą są oczywiście jednostki wtórne, w tym wielokrotne i podwielokrotne) - stosowanych mniej lub bardziej powszechnie - uniemożliwiających łatwe porównania, które są niezbędne do podejmowania racjonalnych decyzji rynkowych (mikroekonomicznych), ale są także niezbędne $\mathrm{w}$ analizach makroekonomicznych.

Te jednostki (stosowane obecnie) to: niutonometr (jednostka SI), dżul (stosowana powszechnie w wypadku ciepła), watosekunda (energia elektryczna), cal (ciepło), BTU (British Thermal Unit), BOE (baryłka ropy umownej), t p.u. (węgiel umowny), ale także $\mathrm{m}^{3}$ (gaz ziemny). W monizmie elektrycznym OZE naturalna (jedyna) jednostką podstawowa jest Ws; jej jednostki wtórne kWh i MWh zwiększają znacznie (do wymiaru powszechnego) możliwość prowadzenia analiz mikroekonomicznych na poziomie intuicyjnym, z kolei jednostka wtórna TWh zapewnia w praktyce duży poziom rozumienia intuicyjnego wyników analiz makroekonomicznych. Dodatkowo podkreśla się, że wat, naturalna (jedyna) jednostka mocy w monizmie elektrycznym, jest zarazem jednostką mocy w układzie SI.

\section{Bibliografia}

Raport jest osadzony w całym środowisku piśmienniczym Powszechnej Platformy Transformacyjnej Energetyki 2050 (http://www.ppte2050.pl). Szczególne znaczenie mają dwa Cykle Raportów: 
- Cykl 12 Raportów Biblioteki Źródłowej Energetyki Prosumenckiej (październik 2017-styczeń 2018)

- Cykl 10 Raportów Biblioteki Powszechnej Energetyki Prosumenckiej (lutylistopad 2018)

- a ponadto Popczyk J., Transformacja energetyki. Paradygmatyczny triplet i mapa oraz trajektoria, raport zamieszczony na platformie PPTE2050, opublikowany w „Śląskich Wiadomościach Elektrycznych” (cz. 1 i 2 - wrzesień 2018, cz. 3 - styczeń 2019)

Datowanie Raportu: wersja alpha, Gliwice, 16 września 2019 r. 